CARLOS EDUARDO RIQUETI

\title{
Uma experiência de auto-gestão de professores e alunos da E.E.S.G. Prof. Ayres de Moura - 1984 a 1994
}

Universidade De São Paulo

Faculdade de Educação

2008 
CARLOS EDUARDO RIQUETI

\title{
Uma experiência de auto-gestão de professores e alunos da E.E.S.G. Prof. Ayres de Moura - 1984 a 1994
}

\author{
Dissertação apresentada como exigência \\ parcial para obtenção do grau de mestre em \\ Educação (Didática, Teorias do Ensino e \\ Práticas Escolares) ao Programa de Pós- \\ Graduação da Faculdade de Educação da \\ Universidade de São Paulo, sob orientação da \\ Profa. Dra. Cecília Hanna Mate.
}

Universidade De São Paulo Faculdade de Educação 2008 
Autorizo a reprodução e divulgação total ou parcial deste trabalho, por qualquer meio convencional ou eletrônico, para fins de estudo e pesquisa, desde que citada a fonte.

Catalogação na Publicação

Serviço de Biblioteca e Documentação

Faculdade de Educação da Universidade de São Paulo

379.81 Riqueti, Carlos Eduardo

R594e Uma experiência de auto-gestão de professores e alunos da

E.E.S.G. Prof. Ayres de Moura - 1984 a 1994 / Carlos

Eduardo Riqueti; orientação Cecília Hanna Mate. São Paulo : s.n., 2008.

91 p. + anexos

Dissertação (Mestrado - Programa de Pós-Graduação em Educação- Área de Concentração: Didática, Teorias de Ensino e Práticas Escolares) - Faculdade de Educação da Universidade de São Paulo.

1. Auto-Gestão 2. Autonomia escolar 3 . Cidadania 4. Participação política I. Mate, Cecília Hanna, orient. 
Para Carlos e Helena Riqueti, pelo apoio incondicional

Para Fernando, pelo exemplo. 


\section{Agradecimentos}

Correndo o risco de eventualmente ter esquecido algum nome, peço, antecipadamente, minhas desculpas. O número de pessoas que tornaram possível esse trabalho é muito grande.

Agradeço a Profa. Dra. Cecília Hanna Mate, minha orientadora, por ter acreditado em mim desde o início, mesmo quando nem eu mesmo tinha certeza da viabilidade dessa pesquisa. Muito obrigado pelo acolhimento.

Meus agradecimentos as Profas. Dras. Flávia Schilling e Maria Aparecida de Aquino pela colaboração imprescindível através do exame de qualificação, que fez tanta diferença na qualidade do meu trabalho.

Sou também infinitamente grato ao Persio, pela ajuda constante, paciente e bem humorada ao longo de todo o meu mestrado.

Obviamente, eu não poderia deixar de mencionar os ex-professores, ex-alunos e ex-companheiros do Ayres de Moura - amigos tão caros, que marcaram tão fortemente minhas práticas pessoal e profissional: Edu, Kohama, Ana Célia, Márcia Helena, Margareth, Joaninha, Cris, Maria Luiza, Marisa, Nardo, Arley e tantos outros...

Agradeço ainda Paulo César, Nilton e Rita, pelo suporte emocional e intelectual, pelo encorajamento e pela paciência constante com que me ouviram e me apoiaram para que esse projeto tivesse êxito. 


\section{Resumo}

No início dos anos 1980, em meio ao efervescente contexto político-social nacional, um grupo de professores e alunos da E.E.S.G. Professor Ayres de Moura, localizada na Vila Jaguara, Lapa, zona oeste da capital paulista, iniciou um movimento que culminou no afastamento do diretor e na apropriação daquele espaço pela comunidade escolar, propiciando condições para práticas didático-pedagógicas arrojadas que ocorreram por aproximadamente dez anos, entre 1984 e 1994. O presente estudo pretende analisar a extensão dessas práticas e seus limites - que subsistem e reclamam para si o direito à memória -, deixando registrado um exemplo alternativo no campo da Educação ocorrido na década de 1980, questionando, dessa forma, o binômio “escola pública/má qualidade”. A análise do processo de auto-gestão instaurado naquela escola busca também refletir acerca da participação direta e efetiva nas decisões dentro do espaço escolar, do significado de participação política, democracia e cidadania, assim como nas relações de poder existentes no cotidiano. Especificamente no tocante às questões didático-pedagógicas, procura entender como o currículo real dessa escola foi trabalhado ao longo desses dez anos em que ela foi gerida pela comunidade. Em outras palavras, procura entender a dinâmica existente entre as esferas política e pedagógica. Para tanto, utilizou como fontes entrevistas com ex-professores e ex-alunos, artigos de jornais e documentos de natureza diversa produzidos pela escola. Atualmente, a E.E.S.G. Professor Ayres de Moura não difere da média das escolas públicas da periferia da cidade de São Paulo, pouco se assemelhando ao que foi durante o período referido por essa pesquisa. Nesse sentido, também se buscou compreender as razões que levaram aquela experiência ao seu esgotamento.

Palavras-chave: auto-gestão, autonomia escolar, cidadania, participação política. 


\begin{abstract}
In the beginning of the 1908's, amidst a roaring social-political national environment, a group of professors and students of the E.E.S.G. Professor Ayres de Moura (located in Vila Jaguara, Lapa, west of Sao Paulo) initiated a movement which had its height with the deposition of their Headmaster. The schooling community then took possession of that space allowing for the appropriate teaching practices to be applied between 1984 and 1994. This work aims at analyzing the extension of such practices and their limits - which exist and claim for themselves the right to memory leaving as a mark an alternative example in the education field which took place in the 1980's decade, questioning the alleged correlation between "state schools vs. poor quality”. The analysis of the self management process adopted by that school looks to reflect over the direct and effective participation within the school space on the meaning of political participation, democracy and citizenship, as well as of the relationships of the existing power of daily life. Specifically on the teaching methodology questions, it looks to understand how the real curriculum was worked during the school creation process undertaken by the community. In other words, the existing dynamics between the pedagogical and political spheres. To that end, interviews with ex-teachers, ex-students and newspaper clippings and documents produced by the school were used. Currently, E.E.S.G. Professor Ayres de Moura does not differ from the average nearby state schools in the outskirts of Sao Paulo, with little resemblance of what was until the mid 1990's. This way, there was also the need to understand the reasons which led to comprehend such experience to come to an end.
\end{abstract}

$\underline{\text { Key words: }}$ self-management, self deciding right to the school, citizenship, political participation. 


\section{Sumário}

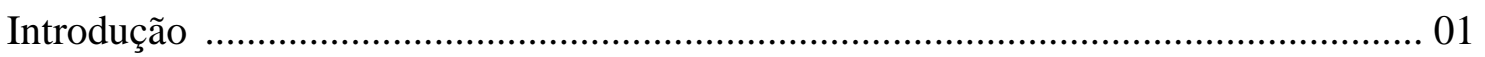

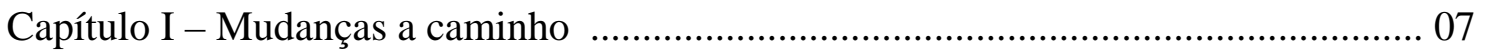

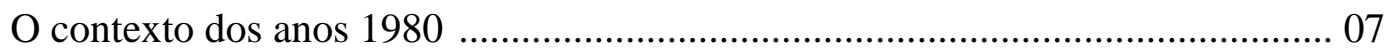

A E.E.S.G. Prof. Ayres de Moura antes do congresso ...................................... 12

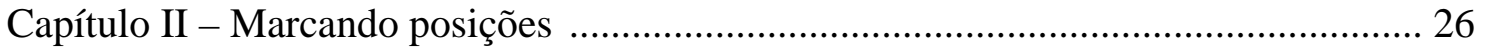

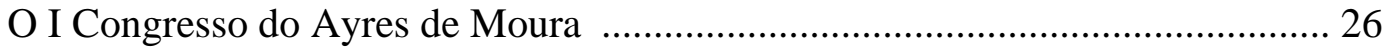

As repercussões do I Congresso ...................................................................... 37

Capítulo III - Entre o político e o pedagógico .......................................................... 45

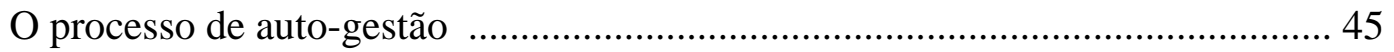

Questões didático-pedagógicas e currículo ........................................................6 66

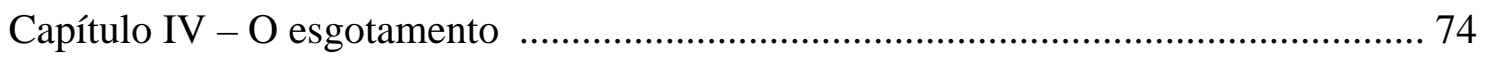

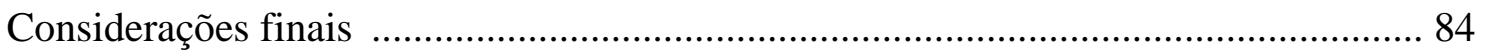

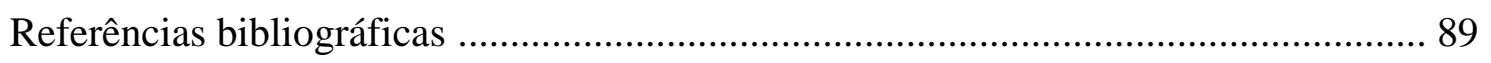




\section{Uma experiência de auto-gestão de professores e alunos da E.E.S.G. Prof. Ayres de Moura - 1984 a 1994}

\section{Introdução}

Até o final dos anos 1970, conforme depoimentos de ex-professores e ex-alunos, utilizados nesse estudo, a E.E.S.G. Prof. Ayres de Moura, localizada na Vila Jaguara, Lapa, zona oeste da capital, pautada por pressupostos pedagógicos assentados na transmissão de conteúdos e na rígida disciplina, em nada se diferenciava da média das escolas públicas da cidade de São Paulo.

Entretanto, o ingresso de professores novos nesse período, com experiências no movimento estudantil, muitos deles tendo inclusive participado das greves do magistério público paulista de 1978 e 1979, e politicamente comprometidos com a oposição ao regime militar, começou a causar certo impacto naquela instituição, ao questionarem os métodos de ensino, a postura da direção da escola, propondo práticas alternativas, ainda que de maneira tímida, no início.

Em 1983, diversos fatores contribuíram para que transformações estruturais ocorressem na escola em questão. Internamente, a assistente de direção, que era, na verdade, quem controlava a escola - de maneira comprometida, porém pessoal e autoritária -, afastouse para trabalhar numa Secretaria de Estado do então recém eleito governador do Estado de São Paulo, Franco Montoro.

Como parte da política educacional do novo governo, foi lançado, nesse mesmo ano, pela Secretaria de Educação, um documento - o Documento $N^{o} .1^{1}$-, que contribuiu para a configuração de um momento de grande atuação de um grupo de professores, alunos e funcionários dentro da E.E.S.G. Prof. Ayres de Moura.

\footnotetext{
${ }^{1}$ A natureza e a grande importância desse documento são analisadas em detalhes no Capítulo II. A reprodução do documento, na íntegra, consta do Anexo II desse trabalho.
} 
As aulas foram paralisadas para que aquele documento fosse discutido. O resultado foi - não sem conflitos - uma proposta de um congresso, no qual, seriam discutidos os problemas que estavam sendo, naquele momento, enfrentados especificamente pela escola.

Assim, o I Congresso da E.E.S.G. Prof. Ayres de Moura aconteceu nos dias 29 e 30 de junho e $1^{\circ}$ de julho de 1983, cujas deliberações, aprovadas pelo voto direto dos diversos segmentos da escola, foram transformadas em um regimento interno que, a partir daquela data e independentemente da oposição da direção, passou a vigorar como base de orientações graças à participação ativa de todos os envolvidos.

Com a deterioração crescente da relação entre a direção e parte do corpo docente, em maio de 1984, após investigações lá ocorridas por meio de uma sindicância solicitada pelos professores à $1^{\text {a }}$ Delegacia de Ensino, houve o afastamento do diretor e coube ao Conselho de Escola escolher um diretor substituto. Foi apresentada uma chapa de candidatas ao cargo de diretora e assistente de direção, que sendo submetida aos alunos em plebiscito, foi aprovada com $94 \%$ dos votos.

Essas professoras, porta-vozes do coletivo da escola que havia se apropriado daquele espaço, propiciaram condições para práticas didático-pedagógicas arrojadas que ocorreram por aproximadamente dez anos. Atualmente, a E.E.S.G. Prof. Ayres de Moura em nada se parece com a escola que existiu entre 1984 e 1994, quando um processo de autogestão foi vivenciado.

Essa experiência, mesmo que pontual e de pouca amplitude em termos quantitativos, levanta uma série de questões de grande importância no tocante a problemas atualmente enfrentados pela escola pública e a complexidade que apresenta. O presente estudo pretende refletir sobre algumas dessas questões.

É senso comum, o fato de que a escola à qual a grande maioria da população brasileira tem acesso - a escola pública - é de má qualidade e grande tem sido a preocupação de vários trabalhos acadêmicos com sua precária situação. Tais estudos configuram um mapeamento minucioso do descaso das gestões governamentais, do despreparo e máformação contínua de educadores e alunos, da crise do papel que a escola ocupa dentro da sociedade, da falta de interesse e indisciplina por parte dos alunos, da violência, e de outros diversos mecanismos que corroboram a exclusão social através do ensino. A lista dos problemas não é nova e nem curta. 
Entretanto, a despeito da contribuição de trabalhos produzidos nessa linha, paradoxalmente vemos reforçada a relação contida no binômio “escola pública/má qualidade”. Estaria a escola pública circunscrita única e exclusivamente a uma realidade que possui a incompetência, o fracasso, o descaso ou a falta de perspectivas como elementos constitutivos? Além disso, a noção corrente de que a escola pública seja um sinônimo de má qualidade, acaba reforçando a idéia de que instituições privadas pressupõem necessariamente características opostas, o que parece ser, no mínimo, questionável.

Numa outra direção, o presente estudo pretende analisar uma experiência no sentido de trazer elementos para a reflexão da relação existente entre participação política e cidadania, inserida nos limites entre o particular (no caso, a escola) e o geral (a sociedade) por meio do relato daqueles envolvidos com a E.E.S.G. Prof. Ayres de Moura no período em questão. Assim, será registrado um exemplo alternativo que aconteceu na década de 1980 na área da Educação, pois fixar-se no viés - tão arraigado na pesquisa educacional - que se limita a ressaltar seus problemas, significa desconsiderar uma série de práticas e experiências que, a despeito de todas as dificuldades, subsistem e reclamam para si o direito à memória.

Não é a primeira vez que o Ayres de Moura é objeto de pesquisa. Dois estudos já foram efetuados sobre essa escola ${ }^{2}$.

Embora Santos (1989) afirme em seu artigo que "a ação social dos professores $e$ alunos do E.E.S.G. Prof. Ayres de Moura, que se mobilizaram questionando as relações de poder e a rígida hierarquia existente no interior da escola e da sociedade, produziu neste microcosmo novas relações sociais e educacionais” (SANTOS: 1989, p. 105), essas relações não foram ainda investigadas.

Souza (1996), ao analisar a experiência ocorrida no Ayres de Moura, busca, entre outras questões, as condições do trabalho docente na década de 1980, as representações sobre esse trabalho e a politização do espaço escolar, sem abordar de modo específico as práticas estritamente pedagógicas.

Assim, apesar da grande contribuição, o que esta pesquisa pretende investigar não foi tomado como questão central pelas autoras, dada a especificidade de cada trabalho.

Além disso, dado o teor da conjuntura política e cultural do momento abordado iniciado no final dos anos 1970 - possivelmente o movimento ocorrido dentro do Ayres de

\footnotetext{
${ }^{2}$ Um artigo de Ediógenes Aragão Santos, publicado em "Cadernos de Pesquisa” da Fundação Carlos Chagas, e um livro de autoria de Aparecida Neri de Souza, "Sou professor, sim senhor!", são ambos constantes das referências bibliográficas.
} 
Moura não foi único. No entanto, por mais que possam ter havido experiências alternativas em outras escolas na mesma época, ainda que de forma pulverizada, jamais chegarão ao nosso conhecimento se estudos e registros não forem feitos: estão fadadas ao desaparecimento, ao esquecimento, caso não venham a ser ouvidas e narradas.

Pensar especificamente no processo de auto-gestão ocorrida naquela escola, levanta a questão - bastante atual - do significado de participar direta e efetivamente das decisões dentro do espaço escolar. Tal pergunta desdobra-se numa série de outras questões, que remetem à reflexão do que é possível entender por participação política, democracia e cidadania, conceitos utilizados atualmente em defesa de posições muitas vezes radicalmente opostas, seja nas práticas político-partidárias, seja nas relações de poder existentes no cotidiano nas quais todos os indivíduos, cientes disso ou não, estão inseridos.

Um dos marcos utilizados para o recorte do objeto desta pesquisa foi o afastamento do diretor da escola em questão - resultado da organização e mobilização da comunidade escolar - e sua substituição por duas professoras da escola, para cargo de diretora e assistente de direção, proposta submetida aos alunos por meio de plebiscito, e referendada pelo Conselho de Escola. Essas professoras, ao assumirem os canais formais de direção, contribuíram para a apropriação do espaço da escola por todos aqueles que a representavam, já que, a partir de então, as decisões seriam tomadas coletivamente, abrindo um espaço livre para a prática docente sobre as mais variadas formas durante aquele período.

Para a narração e a posterior reflexão acerca de tais fatos, buscou-se no Capítulo I, traçar de modo abrangente, um painel do contexto onde o movimento ocorreu: as transformações pelas quais o Brasil passava na virada da década de 1970 para 1980. Ao mesmo tempo, buscou-se captar essas mudanças circunscritas aos muros do Ayres de Moura.

No segundo capítulo, analisa-se o processo que desemboca no I Congresso existente na escola, cuja importância foi fundamental para as repercussões daí derivadas, culminando no afastamento do diretor.

Assim, o processo de auto-gestão em si, as questões didático-pedagógicas, bem como as práticas de professores e alunos - entendendo por práticas desde a implantação de salasambiente, participação dos alunos nas deliberações da escola nos mais diferenciados níveis, entre outros - são objeto do Capítulo III, que pretende compreender como essa experiência possibilitou um currículo mais aberto e relações pedagógicas mais afinadas com as necessidades do momento. Em outras palavras, procura-se compreender o que mudou no 
projeto pedagógico a partir das mudanças políticas: como o currículo real dessa escola foi trabalhado ao longo desses dez anos em que ela foi gerida pela comunidade e ainda, em que medida seus participantes percebiam-se como agentes ativos e conscientes dentro do processo no qual atuaram?

Conforme mencionado anteriormente, o período em questão - os anos 1980 - é inegavelmente caracterizado pela efervescência, seja ela política ou cultural. Assim, se o momento era propício para o repensar e o agir, como o movimento ocorrido dentro do Ayres de Moura respondeu de forma e intensidade tão próprias a esse momento? Supondo essa especificidade a ser investigada, quais foram suas circunstâncias?

Existe ainda, outro ponto importante a ser explorado: atualmente, a E.E.S.G. Prof. Ayres de Moura não se difere da média das escolas públicas da periferia da cidade de São Paulo - depredada e cercada de grades por todas as janelas e muros, pouco se assemelha ao que foi até a metade da década de 1990. Tal constatação implica a tentativa de entender as razões que levaram aquela experiência ao esgotamento. Todas essas questões são abordadas no capítulo IV.

Minha vivência nessa escola como aluno, participante do processo que colaborou para a transformação da escola e, seis anos mais tarde, lá retornando como professor de História, colocou-me em situação singular por diversas razões. Entre elas, pude perceber na prática, como foi trabalhar numa escola que eu havia ajudado a modificar. Além disso, o trabalho de traçar o histórico dos acontecimentos lá ocorridos fez com que muitas certezas tivessem que ser re-elaboradas, ao longo da pesquisa, à medida que novas descobertas se apresentavam.

A análise do ocorrido no Ayres de Moura naquele momento, a partir da perspectiva pessoal não foi um exercício fácil, ainda que tenha sido muito enriquecedor e muito marcante. Muitos, como eu, que de alguma forma partilharam das inúmeras experiências lá ocorridas sejam ex-professores ou ex-alunos - têm suas práticas até hoje por elas influenciadas.

Não é incomum, em encontros casuais com ex-alunos - seja em supermercados, na comunidade do Ayres de Moura no orkut e ainda em outras tantas situações do cotidiano ouvir comentários nostálgicos sobre a escola, sobre as dificuldades da época e de quão diferente está o Ayres de Moura hoje, quando comparado ao que foi no período considerado por esse trabalho, como aquela experiência foi boa, e como hoje tudo está muito mais difícil. 
Saudosismos à parte, é também comum receber notícias de ex-alunos - do magistério, por exemplo -, coordenando projetos educacionais, contribuindo e inovando de alguma maneira em relação às instituições onde hoje atuam.

Isto é, de alguma sorte, reconfortante. De certo modo, o que ocorreu na E.E.S.G. Prof. Ayres de Moura foi pulverizado, re-elaborado, mudou de endereço, mas não acabou por completo: continua nas práticas dos indivíduos que tiveram o privilégio de participar - usando um termo cunhado por Hannah Arendt -, da “felicidade pública” que lá foi construída, ainda que por um tempo determinado.

Como quaisquer outros acontecimentos vivenciados e narrados, a experiência do Ayres de Moura, aqui relatada e analisada, também é passível de distintas visões e interpretações. Este estudo é uma delas. 


\title{
Capítulo I - Mudanças a caminho
}

\section{O contexto dos anos 1980}

O objetivo central desse capítulo é caracterizar, de forma ampla e geral, a virada da década de 1980, período em que o país passava por diversas mudanças, e também momento no qual a experiência ocorrida na E.E.S.G. Prof. Ayres de Moura começa a apresentar seus primeiros sinais.

Vivia-se o esgotamento do regime militar e, partindo dos mais variados segmentos da sociedade, tentativas de retomar os valores democráticos ganhavam maior intensidade nesse momento, num jogo de forças extremamente complexo.

Analisando alguns dos inúmeros movimentos sociais ocorridos no Brasil durante esse período, $\operatorname{Sader}^{3}$ (1995) afirma que

\begin{abstract}
“[...] eles não apenas emergiam fragmentados, mas ainda se reproduziam enquanto formas singulares de expressão. Ou seja, embora tenham inclusive desenvolvido mecanismos de coordenação, articulação, unidade, eles se mantiveram como formas autônomas de expressão de diferentes coletividades, não reduzíveis a alguma forma 'superior' ou 'sintetizadora'. [...] Os movimentos sociais tiveram de construir suas identidades enquanto sujeitos políticos precisamente porque elas eram ignoradas nos cenários públicos instituídos. Por isso mesmo o tema da autonomia esteve tão presente em seus discursos.” (p. 198-199).
\end{abstract}

Dessa forma, paralela ou subjacentemente ao que ocorria na esfera políticopartidária, mudanças e resistências ocorriam aqui e ali, revelando, tanto no macro como no micro, a efervescência que tão fortemente marcou o período em questão.

A extinção do AI-5 ${ }^{4}$, ao final do ano de 1978, por exemplo, pôs fim às arbitrariedades do poder executivo, extinguindo-lhe o poder de cassar parlamentares, declarar

\footnotetext{
${ }^{3}$ SADER, Eder. Quando novos personagens entram em cena: experiências e lutas dos trabalhadores da grande São Paulo (1970 a 1980). 2a . ed. Rio de Janeiro: Paz e Terra, 1995.

4 "O Ato Institucional n'. 5, AI-5, baixado em 13 de dezembro de 1968, durante o governo do general Costa e Silva, foi a expressão mais acabada da ditadura militar brasileira (1964-1985). Vigorou até dezembro de 1978 [gestão Geisel] e produziu um elenco de ações arbitrárias de efeitos duradouros. Definiu o momento mais duro
} 
recesso no Congresso Nacional e privar cidadãos dos seus direitos políticos, entre outros. No entanto, os artigos 155-158 da Emenda Constitucional $\mathrm{n}^{0}$ 11, aprovada pelo Congresso no mesmo ano (SKIDMORE, 2004, p. 396) ${ }^{5}$, permitiam ao poder executivo decretar "medidas de emergência” ou estado de sítio sem aprovação legislativa.

De forma análoga, é também possível perceber na lei da anistia, sancionada em agosto de 1979, o fator ambigüidade. Indiscutivelmente, a possibilidade do retorno ao país de personagens que haviam sido afastados no cenário político com o golpe militar de 1964 - e isso sem dúvida não correu sem o concurso de pressões da sociedade civil -, significou um largo passo rumo à redemocratização do país. Entretanto, a anistia foi, ao mesmo tempo, utilizada como

“[...] bandeira para justificar determinado jogo político. Componentes da classe dirigente passaram a utilizá-la como forma de legitimar o projeto de mudança em marcha. [...] Tendo sido superada a preocupação da última metade da década de 1970 dos setores dominantes de que a Anistia poderia ameaçar a tranqüilidade social, floresceu a defesa da necessidade de eliminação do arbítrio por etapas, para garantir bons resultados. Não interessava para a maioria dos estratos dominantes da classe burguesa [...] o endurecimento do Regime. Viam a possibilidade de implementar uma Democracia dentro dos moldes entendidos por estes setores.” (REZENDE, 1991, p. 119-120) ${ }^{6}$

Ainda no ano de 1979, uma reforma na legislação eleitoral extingue o sistema bipartidário ARENA - MDB que havia sido instituído a 20 de novembro de $1965 .{ }^{7} \mathrm{O}$ primeiro representava as forças do governo, enquanto que o segundo partido, de oposição, aglutinava representantes das mais variadas posições, uma vez que era a única alternativa não clandestina possível de participar oficialmente do jogo político.

do regime, dando poder de exceção aos governantes para punir arbitrariamente os que fossem inimigos do regime ou como tal considerados - Maria Celina D'Araújo”. Para maiores detalhes, consultar site do CPDOC Centro de Pesquisa e Documentação de História Contemporânea do Brasil, da Fundação Getúlio Vargas, Rio de Janeiro. <http://www.cpdoc.fgv.br/nav fatos_imagens/htm/fatos/AI5.htm>. Acessado em 06 out. 2006.

${ }^{5}$ SKIDMORE, Thomas. Brasil: de Castelo a Tancredo, 1964 - 1985. 8 ed. Rio de Janeiro: Paz e Terra, 2004. Os dados acima e outros apresentados ao longo desse capítulo foram obtidos nessa obra.

${ }^{6}$ REZENDE, Maria José de. A transição como forma de dominação política: o Brasil na era da abertura (1980 a 1984). 1991. Dissertação (Mestrado). PUC, São Paulo, 1991.

7 “[...] em cumprimento ao disposto no AI-2 [ato institucional $n^{\circ} 2$ 2], em 20 de novembro foi expedido o AC- 4, [ato complementar $n^{\circ} 4$ ] definindo as regras a serem seguidas na reorganização partidária. As limitações dessas regras permitiriam que se formassem apenas duas agremiações: de um lado, o partido governista Aliança Renovadora Nacional (Arena) e, de outro, o Movimento Democrático Brasileiro (MDB) - Vera Calicchio e Dora Flaksman". Para maiores detalhes, consultar <http://www.cpdoc.fgv.br/dhbb/verbetes_htm/5744_1.asp>. Acessado em 06 out. 2006. 
O resultado dessa reforma foi a criação de diversos partidos políticos: o PDS, Partido Democrático Social, que representava o próprio governo, podendo ser considerado um rearranjo da antiga ARENA; mais ao centro, formou-se o PP, Partido Popular, que tinha como líderes em nível nacional Tancredo Neves e Magalhães Pinto; o PMDB, Partido do Movimento Democrático Brasileiro; o PTB, Partido trabalhista Brasileiro; e o PDT, Partido Democrático Trabalhista. E mais à esquerda destes, o PT, Partido dos Trabalhadores.

Essa reformulação, todavia, à medida que ganhava mais espaço rumo à democracia, era também uma estratégia do governo que, ao mesmo tempo em que concentrava suas forças num único partido, fragmentava a oposição.

Ainda sobre a reforma partidária, Rezende (1991) argumenta:

\begin{abstract}
“[...] a implantação do Pluripartidarismo não decorreu de uma decisão militar. Os diversos setores sociais que se organizavam naquele momento, impunham essa necessidade, que foi encampada pelos militares, numa situação em que, inclusive alguns estratos burgueses [...] exigiam formas e canais de manifestação de seus interesses e descontentamentos. [...] Havia exigência de que o jogo político fosse refeito, e esta era a forma de estabelecer algumas mudanças, suscitadas por diversos setores sociais, sem causar perdas para os ‘donos do poder’.” (p. 130-131)
\end{abstract}

Os exemplos acima selecionados - a extinção do AI-5, do sistema bi-partidário e a aprovação da Lei de Anistia - procuram mostrar como o processo de redemocratização e a extinção gradual da ditadura militar implicaram mudanças que por muitas vezes avançavam em determinados aspectos e, paradoxalmente, tinham a função de manter outros inalterados, ainda que sob uma aparência diferente.

Essa conclusão, entretanto, não nega, nem desqualifica os ganhos reais e as conquistas dos diversos setores da sociedade civil.

Os trabalhadores, por exemplo, não obstante os esforços e resistências - e longe de formarem um bloco coeso dentro do panorama que aqui se apresenta - vinham sofrendo inúmeras investidas ao longo dos anos, e encontravam-se, por inúmeras razões, desmobilizados. Entretanto, nesse período, um novo tipo de movimento sindical rompeu com a maneira pela qual a grande maioria dos sindicatos vinha funcionando até então, compactuados com o regime ditatorial. 
Em maio de 1978, uma greve foi deflagrada em São Bernardo do Campo, São Paulo, com 2.500 metalúrgicos sob o comando de Luís Inácio Lula da Silva. Essa greve veio a ser um exemplo seguido por outras 90 empresas que, num período de 10 dias, paralisaram apenas na região da grande São Paulo, 500.000 empregados. Entre janeiro e outubro de 1979, entre trabalhadores de setores os mais diversos, registrou-se mais de 400 greves ao longo de todo o país (SKIDMORE, 2004, p. 400).

No caso dos professores, especificamente, não foi diferente. A APEOESP Sindicato dos Professores do Ensino Oficial do Estado de São Paulo -, também tinha seu controle concentrado numa sucessão de diretorias submetidas às exigências da ditadura. Em meio a intensos conflitos internos que vieram a transformar a instituição, uma assembléia com dois mil participantes - à revelia de sua diretoria -, inicia uma greve em 19 de agosto de 1978, que teve a duração de 24 dias $^{8}$.

As pressões e manifestações não se faziam visíveis apenas em meio aos trabalhadores. Entre os setores dominantes, que haviam apoiado o golpe de 1964 frente às pressões esquerdistas daquele momento, muitos estavam descontentes e almejavam reduzir o peso do papel do Estado na economia.

Divergências também estavam presentes entre as forças que compunham o governo militar. Um indicador disso foi a constante resistência, ora mais, ora menos explícita, de setores militares - conhecidos como "linha dura", contrários aos membros do governo favoráveis à “descompressão”, ou seja, a retirada gradual dos militares do cenário político. Muito mais do que diferenças políticas, a ação dos membros da linha dura reforçava ainda mais a turbulência do momento. Alguns exemplos quanto a esse respeito podem ser citados: bancas de jornal incendiadas; ameaças a donos de estabelecimentos que se propusessem a vender publicações com conteúdo caracterizado politicamente como “de esquerda”; uma carta-bomba enviada à sede da $\mathrm{OAB}$, matando uma pessoa, e ainda, um episódio que ficou conhecido como o “caso do Riocentro” em 1981 - quando uma bomba explodiu num carro matando um sargento e ferindo gravemente um capitão do Exército no local onde se realizava um show em homenagem ao dia do trabalho. Presume-se que a bomba destinava-se à por fim a uma manifestação em prol de causas oposicionistas que neste local ocorria ${ }^{9}$.

\footnotetext{
${ }^{8}$ Foi utilizado como fonte o Jornal da APEOESP n ${ }^{\circ} 266$ (nov. a dez. 2004) e no 267 (abr. a maio 2005) e também o artigo "História da Apeoesp - de associação assistencialista e antidemocrática a um sindicato combativo e democrático", retirados do site da APEOESP: <http://www.apeoesp.org.br/historia/index.htm>. Acessado em 15 nov. 2006.

${ }^{9}$ Para maiores detalhes, indica-se o item Explosões à direita do Capítulo VII da obra já citada de Thomas Skidmore e também a vasta fonte documental, lá citada, sobre o assunto.
} 
Outro acontecimento relevante nesse período foi a aprovação, em 1980, de uma emenda constitucional que restabelecia a eleição direta para candidatos em todos os níveis, com exceção do presidente. As eleições, realizadas em 1982, têm como resultado a conquista, pela oposição, de grande espaço no cenário político:

\begin{abstract}
“A oposição agora tinha o controle de estados-chave, mas o governo detinha firmemente o Executivo federal. Os governadores oposicionistas Franco Montoro, de São Paulo, Leonel Brizola, do Rio de Janeiro, Tancredo Neves, de Mina Gerais, e José Richa, do Paraná, não tinham condições de empreender experimentos radicais. Assumindo o poder em meio à pior recessão do Brasil desde a década de 30 , eles precisavam muito da ajuda financeira e de outras formas de cooperação de Brasília. [...] Graças à abertura, a oposição chegava ao poder, mas justamente numa hora em que a economia se achava em pleno declínio.” (SKIDMORE, 1988, p. 457-458)
\end{abstract}

Os governos de oposição que assumiam nos Estados em 1983, tinham grandes obstáculos a transpor. As dificuldades econômicas afetavam o país como um todo, além da delicada relação entre ser o governo local e a oposição no âmbito federal. Além disso, os dispositivos repressores mais truculentos da ditadura já não impediam que a sociedade civil pudesse exteriorizar suas expectativas e necessidades de forma direta e explícita.

No campo específico da educação no estado de São Paulo, o recém-eleito governador Franco Montoro, e seu secretário, Paulo de Tarso - ex-ministro da educação do governo João Goulart, deposto em 1964 pelos militares - tinham muito trabalho pela frente: lidar com uma situação que há muito carecia de mudanças. Havia a preocupação em imprimir um caráter democrático na nova administração, diametralmente oposta à anterior, de forte teor autoritário. As expectativas entre os professores não eram poucas ${ }^{10}$.

É dentro desse contexto de efervescência política e cultural, de expectativas e reformulações, que as alterações na realidade da escola objeto desse estudo, a E.E.S.G. Prof. Ayres de Moura, começam a se delinear.

\footnotetext{
${ }^{10}$ Além da situação dos professores, há muitos outros aspectos que fornecem elementos para uma compreensão mais abrangente dessa questão, tais como a estrutura da máquina administrativa, que terminava por criar inúmeros obstáculos aos projetos do novo governo; os problemas internos dentro do PMDB; os conflitos entre as oposições e outros ainda, objeto de estudo da dissertação de mestrado de Sônia Ribeiro, constante das referências bibliográficas.
} 


\section{A E.E.S.G. Prof. Ayres de Moura antes do congresso}

"Em que escola um aluno dança rock com a diretora?”

(ex-professor)

“[...] teme-se que a cultura de massa empobreça 'nossas memórias originais' e que uma versão mais homogeneizada tome seu lugar. Teme-se também perder a comunidade e a identidade, já que a tecnologia de massa modifica não só nosso sentido temporal, mas também a natureza especificamente espacial do lembrar. A noção de que podemos nos 'lembrar', por exemplo, do assassinato de Kennedy significa que nos lembramos de como foi apresentado na televisão ou no rádio, e não de termos a experiência direta desse evento.” (THOMSON; FRISCH; HAMILTON, 2005, p. 90) ${ }^{11}$

O trabalho de caracterização do “Ayres de Moura” neste período - final da década de 1970 - e a posterior análise do que lá ocorreu implicou a utilização de fontes escritas como, por exemplo, artigos de jornais, documentos produzidos pela escola - atas de reuniões, documentos resultantes de assembléias, textos produzidos e utilizados por professores e alunos - às vezes de autoria conjunta - programas de feiras culturais e atividades pedagógicas diversas, e ainda, comunicados expedidos pela direção.

Foram também utilizadas fotografias cedidas por ex-professores e alunos, além do uso de fontes orais, ou seja, entrevistas com professores e alunos da escola. Especificamente com relação a este ponto, cabem aqui algumas rápidas considerações.

O lançar mão de relatos orais na elaboração de estudos acadêmicos vem percorrendo um longo caminho. Nem mesmo a utilização da terminologia - história oral - que comumente é usada para se referir à concepções distintas, é consensual, uma vez que determinadas vertentes a consideram uma disciplina em si mesma. Entretanto, a despeito das divergências, é fato que pesquisadores partidários de entendimentos distintos têm utilizado fontes orais na elaboração de suas pesquisas. Isto provavelmente porque - entre outros fatores - o debate em torno da objetividade da história e a busca pela verdade, pela recuperação do passado tal como aconteceu, também seja, hoje, uma questão ultrapassada.

\footnotetext{
11 THOMSON, Alistar; FRISCH, Michael; HAMILTON, Paula. Os debates sobre memória e história: alguns aspectos internacionais. In: FERREIRA, Marieta de Moraes; AMADO, Janaína (Orgs.). Usos e abusos da história oral. Rio de Janeiro: Fundação Getúlio Vargas, 2005, p. 63-91.
} 
Considerando a história - ainda que de modo simplificado - como a ciência que estuda a trajetória dos homens e suas relações através do tempo, é preciso lembrar que o eterno retorno do historiador ao passado é movido por questões por ele ou a ele colocadas, dentro do seu tempo. As questões são, elas próprias, historicamente determinadas. É a historicidade da própria história.

\begin{abstract}
"Na Grécia, a História traduziu-se por uma concepção reflexiva e metodológica. Em Roma, destacou-se por seu caráter utilitário, patriótico e moral. Na Idade Média, retomou uma perspectiva filosófica, abstrata e, de certa forma, transcendental. Com o Renascimento explodiu em humanismo e antropocentrismo seculares. No período do iluminismo foi reconhecida como fonte de conhecimento, afirmativo da razão e contraposto à tradição. O Positivismo buscou transformá-la em área específica de conhecimento, neutra, descritiva e com fronteiras bem definidas. O marxismo afirmou sua dinâmica através de relação dialética e estrutural entre a vida material e a vida social. A Escola dos Annales rompeu fronteiras, adotou a interdisciplinaridade, renovou metodologias e temáticas, além de incorporar uma nova forma de narrativa, à qual se acopla a reflexão." ${ }^{\prime 2}$ (DELGADO, 2006, p.41)
\end{abstract}

E assim sendo, se as questões propostas pelo historiador recolocam-se e transformam-se incessantemente, a busca que ele empreende pelo passado é constante. Entretanto, se a recuperação do passado na sua íntegra, tal e qual aconteceu, é tarefa impossível, se ele sabe que chegará, no máximo, a recuperar fragmentos, vestígios, impressões e interpretações, quais seriam então as razões de sua insistência?

Talvez, na verdade, ele e/ou nós busquemos o lastro, as referências das quais dispomos para seguir no infindável intento de composição das nossas identidades. E são exatamente esses fragmentos, esses vestígios e essas impressões aquilo que podemos entender como memória.

Muitas vezes confundido, reduzido ao ato de lembrar, o conceito de memória possui fluidez e extensão inimagináveis. A memória vai muito além da lembrança. Num exemplo o mais simplificado possível - e circunscrito ao plano individual - o que podemos dizer hipoteticamente de uma pessoa que “perde” a memória? A capacidade de lembrar pode estar ainda presente, porém, não há o que ser lembrado. Todas as referências, os elementos constitutivos de sua identidade, que até então guiavam suas condutas, compunham seu código

12 DELGADO, Lucília de Almeida Neves. História oral: memória, tempo, identidades. Belo Horizonte: Autêntica, 2006. 
moral pessoal, direcionavam suas ações futuras, foram solapadas, nada mais restando a não ser um vazio, um não-saber, um não-ser.

Estendendo esse raciocínio - ainda movido por hipóteses - para o plano coletivo, torna-se mais fácil vislumbrar o que este trabalho entende como memória.

Sendo assim, não é surpreendente que, frente à fragmentação e à ambivalência que tão bem caracterizam as sociedades do mundo contemporâneo, as pesquisas no campo da História tenham estreitado o diálogo travado com outras áreas do conhecimento, colocando o particular, o subjetivo e a memória no centro de suas preocupações e em detrimento de generalizações que parecem não satisfazer as necessidades colocadas nem tampouco dar conta dos atuais desafios postos. A questão da preservação da memória da experiência ocorrida no Ayres de Moura é, dessa forma, um dos motivos desse estudo.

Para tanto, o passo seguinte foi construir o quadro que caracteriza a escola, a partir de meados da década de 1970, feita com a colaboração imprescindível de ex-professores e exalunos que, ao relatar suas experiências ao longo dos diferentes momentos do processo, tornaram possível esse estudo.

Paradoxalmente, essa ajuda foi fonte de outros problemas. Havia a questão do constante esforço no sentido de equacionar a vontade de transpor a densa camada emocional que todos os depoentes traziam, mesmo sabendo ser isso impossível - afinal, por pior que tenha sido a experiência escolar individual de cada um, há sempre certa nostalgia ao relembrá-la. Havia também outras questões, de ordem pessoal. Minha vivência nessa escola como aluno, participante do processo de transformação da escola e, seis anos mais tarde, lá retornando como professor de História, colocou-me em situação singular por diversas vezes: certezas e conceitos que trazia comigo desde as experiências vivenciadas ao longo do processo, foram constantemente re-elaboradas, à medida que a pesquisa avançava e novas descobertas se apresentavam. Diversos estudiosos auxiliaram na reflexão acerca dessas questões:

“Composição é um termo adequadamente ambíguo para descrever o processo de 'construção' de reminiscências. [...] Ao narrar uma história, identificamos o que pensamos que éramos no passado, quem pensamos que somos no presente e o que gostaríamos de ser. As histórias que relembramos [...] trazem aspectos desse passado e os moldam para que se ajustem às nossas necessidades e aspirações atuais.” (THOMSON, 1997, p. 56-57) ${ }^{13}$

\footnotetext{
13 THOMSON, Alistar. Recompondo a memória: questões sobre a relação entre a história oral e as memórias. Projeto História, n. 15, abr. 1997, p. 51-84.
} 
“[...] a memória é uma reconstrução psíquica e intelectual que acarreta de fato uma representação seletiva do passado, um passado que nunca é aquele do indivíduo somente, mas de um indivíduo inserido num contexto familiar, social, nacional. Portanto toda memória é, por definição 'coletiva', como sugeriu Maurice Halbwachs. Seu atributo mais imediato é garantir a continuidade do tempo e permitir resistir à alteridade, ao 'tempo que muda', às rupturas que são o destino de toda vida humana [...], mas essa percepção difere segundo nos situemos na escala do indivíduo ou na escala de um grupo social [...] se o caráter coletivo de toda memória individual nos parece evidente, o mesmo não se pode dizer da idéia de que existe uma [...] representação do passado que sejam compartilhadas nos mesmos termos por toda uma coletividade.” (ROUSSO, 2005, p. 94-95) ${ }^{14}$

Balizado por esses autores, estava claro que as entrevistas não visavam à veracidade dos depoimentos, e nem as distorções, nem os silêncios, eram obstáculos. Ao contrário, tais ocorrências podiam ser, inclusive, elementos que viessem a enriquecer as análises. Além disso, esse enfoque frente aos relatos não excluiu a utilização de fontes de outra natureza, não no sentido de obtenção de contraprovas, mas sim como forma de ampliar a compreensão do objeto, apreendendo suas diferentes dimensões.

Dessa forma, as questões acima expostas estiveram sempre presentes, tanto na caracterização do Ayres de Moura em seus aspectos mais gerais, bem como na seleção e análise das falas dos depoentes.

A E.E.S.G. Prof. Ayres de Moura, localizada na Vila Jaguara, Lapa, zona oeste da capital, no final da década de 1970, seguia normas pedagógicas tradicionais - no sentido da ênfase na transmissão do conteúdo e também da disciplina, entendida como bom comportamento dos alunos, ordem e silêncio. Grande era a procura por vagas naquela escola, inclusive, por ser uma das poucas a oferecer o curso de segundo grau (atual Ensino Médio) na região, atendendo, além do próprio bairro, a alunos de diversas regiões: Jardim Santo Elias, Vila Mangalot, Parque São Domingos, Vila dos Remédios, Jardim Marisa, parte de Osasco, entre outros.

"O decreto de criação do então Ginásio Estadual Prof. Ayres de Moura (GEPAM) data de 24 de julho de 1965. Até então funcionava no prédio somente uma escola primária. A criação do segundo grau ocorreu em 03 de junho de 1970, passando, portanto, a funcionar no prédio os três níveis de

\footnotetext{
${ }^{14}$ ROUSSO, Henry. A memória não é mais o que era. In: FERREIRA, Marieta de Moraes; AMADO, Janaína (Orgs.). Usos e abusos da história oral. Rio de Janeiro: Fundação Getúlio Vargas, 2005, p. 92-101.
} 
ensino. O Colégio Estadual Prof. Ayres de Moura funcionou na Vila dos Remédios até a construção do prédio atual, cuja instalação ocorreu em 1973. Em 1972, com a expansão obrigatória da escola primária de 4 para 8 anos, o GEPAM passou a receber o nome de E.E.P.G. José Altenfelder da Silva. O prédio atual do E.E.S.G. Prof. Ayres de Moura foi oficialmente ocupado em 1976.” (SANTOS, 1989, p. 102)

O bom funcionamento do Ayres de Moura devia-se, na verdade, à assistente de direção - no presente estudo, identificada por “I.” - que era quem realmente dirigia a escola, muitas vezes de forma autoritária, uma vez que o diretor - identificado por "D." - apresentava dificuldades em lidar com quaisquer questões fossem elas de ordem administrativa e/ou pedagógica. Ao longo de todos os depoimentos foi mencionada a característica omissa do diretor e a presença marcante da assistente de direção:

E.: $\quad$ No começo eu achei a 'I.' muito pretensiosa. Já no segundo ano que eu fiquei no GEPAM, eu me efetivei, porque era uma escola séria. Acho que em parte por causa da 'I.' ser uma pessoa que tomava conta da escola. A escola era bonita, bem cuidada, os alunos eram ótimos, era muito gostoso dar aula no GEPAM. A 'I.' era uma pessoa que regava as plantas pessoalmente, ela queria tudo de melhor prá escola dela, que ela era dona, entende? Quem ela achava que dava aula boa - e ela percebia, porque não era boba - ela respeitava. Era uma pessoa de direita, não uma direita selvagem, é lógico, mas era uma pessoa conservadora. Só que ela respeitava qualquer pessoa que achasse que fosse trabalhadora... Não era o principal ser de esquerda ou de direita, era uma época dura, de ditadura. Quem era trabalhador, sério, inteligente, que fazia coisas pela escola dela, era respeitado.

K.: $\quad$ Na verdade eu nunca vi o 'seu D.' muito envolvido com as coisas da escola. Tanto é que eu fui saber que ele era diretor depois de algum tempo. Ele aparecia lá na escola, porque a 'I.' ficava mais à noite. Durante o dia, o 'seu D.' ficava lá. Mas para mim, a 'I.' era a diretora. Ela se comportava como diretora. Era ela quem mandava.

\footnotetext{
${ }^{15}$ SANTOS, Ediógenes Aragão. Participação, autonomia e co-gestão na escola pública. Cadernos de Pesquisa. São Paulo: Fundação Carlos Chagas, n. 68, 1989, p. 99-105.
} 
A.C.: A 'I.' trabalhava muito, foi uma pessoa que se dedicou à escola. Ela estava lá 24 horas. Tinha nas mãos toda a escola.

Ao investigar se, desde o final da década de 1970, a escola destoava de alguma forma da média das outras escolas públicas da época, as opiniões variaram, provavelmente por conta das impressões que os professores, ao iniciarem no Ayres de Moura, traziam de outras escolas. De qualquer modo, fica evidente a postura autoritária e comprometida da assistente de direção e da boa qualidade do serviço prestado pela escola de modo geral, ainda que funcionando dentro de moldes tradicionais.

K.: $\quad$ Eu acho que era diferente, desde o começo. A 'I.' era uma pessoa muito preocupada com a educação. Ela dava apoio para o professor. Eu tive muito apoio dela. No começo foi difícil, a 'I.' agia como se ela fosse dona da escola, esse lado era negativo. Mandava e desmandava, mas depois, eu acho que ela foi me conhecendo, eu fui conhecendo a 'I.' e ela me apoiou bastante.

E.: $\quad$ No começo, não destoava muito. Tinha boas instalações, isso é fundamental, tinha um prédio muito bom, com muito espaço, inclusive mal-utilizado. No final dos anos 70, ainda não tinha esse abandono da escola pública. Havia bons professores na escola. O nível do professor era muito bom. Eu lembro que quando entrei no GEPAM, me impressionou que tinha um professorado, muitas vezes de postura tradicional, mas excelente.

A.C.: Eu não senti isso no início. Tinha todos os problemas que qualquer escola tem. Aquele 'auê' de chegar sexta-feira e não ter aula, de juntar três ou quatro salas prá dar uma aula, eu acho que era uma escola bem 'padrãozão' mesmo. Era boa, mas apresentava todos os problemas que qualquer outra escola tinha. Não havia nenhum diferencial.

C.M.: [A 'I.'] era autoritária, tradicional, mas [na escola] tinha discussão. Era diferente da outra escola que eu tinha vindo, onde não se podia falar nada. Todo mundo falando baixinho, olhando o diretor, tinha medo. O Ayres sempre teve um movimento, uma certa bagunça assim, entre aspas, entende? Nunca foi uma escola parada. A 'I.' não 
cortava. Tentava, às vezes, mas... eu acho que eu entrei bem no momento em que talvez ela não estivesse tão forte.

Ainda no final da década de 1970, principalmente a partir de 1978, o gradativo ingresso de novos professores - muitos na condição de efetivos - acarreta uma série de transformações na escola, ainda que não abruptamente. Com o passar do tempo, configura-se dentro do corpo docente uma divisão entre "velhos” e "novos”.

E.: Você tinha professores bons, mas de perfil mais conservador. Quem que entrou comigo? Eu, a 'K.' e depois o 'A.', mais tarde o 'N.', a 'C.', eram pessoas vindas do movimento estudantil, em geral, que tinha participado de 68 ou de 77. Mais tarde a 'M.' entrou também, então era um perfil de pessoal que tinha uma faculdade assim, politizada. Gente de boas faculdades e que tinham participado do movimento estudantil. Entre esse pessoal, havia uma coisa de querer fazer diferente. Para mim, dar aula era uma forma de militar. Não era simplesmente ser professor, uma profissão. Eu sabia que eu era militante. E de certa forma eu acho que as outras pessoas também tinham isso, militavam. A gente tem que ver também o fato de que ainda não era tão proliferada o que a gente chama de 'faculdade de beira de estrada'.

K.: $\quad$ Eu sentia assim, o pessoal mais antigo não conversava com o pessoal mais novo. Mal cumprimentavam a gente. Eu vejo dois grupos, um mais antigo e um outro, de professores recém-chegados.

Entretanto, a forte divisão presente dentro do grupo docente parecia não explicar-se apenas a partir do ponto de vista da militância.

A.C.: Isso [a divisão] era bem forte. Porque nessa época entraram vários professores novos e efetivos. É muito difícil você chegar na condição de efetivo numa escola. Por força das circunstâncias, a gente é obrigado a tirar as aulas dos outros. Não é nem tirar, a realidade é essa, o sistema é assim. Então cria uma certa rivalidade. E essa rivalidade é bastante forte. Prá você ir conquistando as pessoas foi difícil. Foi demorado e, mesmo assim, alguns não conseguiram. Participação política, eles 
também tinham. Não era também uma diferença de idade. É mais uma questão de estar mesmo com as raízes lá e hostilizar quem está chegando. [Com relação à experiência política na universidade]: eu tinha muito medo. Eu peguei uma época muito complicada. O curso tinha acabado de mudar aqui prá Cidade Universitária, antes era lá na Maria Antônia, tinha sido invadido lá. Eu tive professores que, durante a minha aula, foram tirados da sala e nunca mais foram vistos. Durante a aula, na minha frente, entraram duas pessoas, falaram alguma coisa, pegaram no braço da minha professora de lingüística - a Alda Natal -, ela colocou o giz na lousa e saiu com eles. Nunca mais tivemos notícia dela. Era uma época muito complicada. Tinha canhões na Praça da Sé, então a gente tinha muito medo, eu passava longe do centro acadêmico. Então realmente eu não participava. Acho que, pelo menos eu e a 'K.', não tínhamos esse passado de militância. Eu acho que o problema era mais: 'olha você chegou e está tirando as nossas aulas, está botando nossos amigos prá fora, por sua causa, fulano e fulano saíram, estão desempregados’.

Os depoimentos selecionados auxiliam, dessa forma, na visualização da diversidade que caracterizava o corpo docente do Ayres de Moura naquele momento. Questões como a qualidade da formação dos professores, o entendimento do significado da atividade docente, o engajamento político e mesmo questões de ordem administrativa/institucional, combinavamse, influenciando umas as outras. Depreende-se então que, com a entrada, ainda que paulatina, desses novos professores, todo o grupo sofreu transformações, demandando por parte de todo o conjunto novos posicionamentos, associações, revisão de práticas, estranhamentos, identificações - dinâmica esta que vai muito além da constatação de dois pólos antagônicos.

Em termos estritamente pedagógicos - apesar do caráter eminentemente tradicional da escola como um todo, da inexpressividade do diretor e da tônica pessoal e arbitrária da assistente de direção - algumas atividades diferenciadas, além das aulas formais, surgiram no Ayres de Moura desse período.

Dois exemplos parecem significativos, já que foram lembrados por vários professores. Além disso, contribuem no sentido de entender melhor a dinâmica do relacionamento entre os professores e a direção em âmbito geral da escola. Um deles foi a Semana de Arte, realizada em novembro de $1980^{16}$.

\footnotetext{
${ }^{16}$ Programa reproduzido na íntegra, constante do Anexo I.
} 
A.C.: Teve uma feira cultural que causou uma grande mobilização. Foi a Semana Cultural. Nós levamos escritores para palestras, foi uma feira muito boa. Consegui contatar o Loyola Brandão. Eu tinha ido a uma bienal, tinha conversado com ele, nós fomos buscá-lo, ele não cobrou nada, foi no início da carreira dele. Foi também um amigo meu, especialista em literatura infantil, fazer palestra lá. Foi muito legal.

E.: $\quad$ Teve, mas era feira cultural dentro dos parâmetros da 'I.'. Era para os alunos fazerem a feira, com obras dos alunos. Ela apoiou, só que do jeito dela. Então a gente acabava fazendo uma coisa meio misturada, quer dizer, teve obras de alunos, mas teve obras de pintores, amigos dela. A 'I.' achava que você tinha que trazer grandes artistas prá mostrar aos alunos e eu queria fazer uma coisa da produção deles. Então a gente acabou fazendo as duas coisas. Essa relação perdurou enquanto a 'I.' foi diretora de escola, quer dizer, a gente fazia concessão à 'I.' e ela fazia concessão à gente.

Outro exemplo eram as viagens às cidades históricas de Minas Gerais: São João del Rey, Congonhas do Campo, Mariana e Ouro Preto, organizadas por um dos professores de História, inicialmente em 1982, projeto que acontecia anualmente e durou vários anos.

K.: $\quad$ As viagens que o 'E.' fazia já aconteciam antes do congresso. Até um ex-aluno que eu encontrei se lembrou das viagens prá Ouro Preto: 'O 'E.', que saudade! Ele me abriu a cabeça, nós fomos nessa viagem prá Ouro Preto, é uma coisa que eu não esqueço mais!' Isso marcou muito.

E.: $\quad$ Foi em 1982. O 'A.' que organizou a primeira excursão prá Minas Gerais, mas a idéia era minha. A 'I.' achou ótimo ir pras cidades históricas - ela era inteligente, achava que era uma coisa boa. O 'seu D.' achava que a viagem era uma desculpa para não dar aula, e ele não quis. A 'I.' disse: 'vai, e pronto!' Ela confiava na gente, porque se não confiasse, ela vetava. 
Além das atividades acima mencionadas, a partir de 1981, e à medida que novos professores iam chegando à escola, outras começaram a acontecer com mais freqüência e em maior número: excursões ao Jardim Botânico, Zoológico, participação no programa "É proibido colar” da TV Cultura, entre outros. É necessário ressaltar que nenhuma atividade foi caracterizada como partindo dos professores que lá estavam anteriormente ao período em questão. Conclui-se, portanto, que à medida que o grupo de professores "novos" tomava corpo, começavam também a imprimir suas marcas no pedagógico da escola. Mesmo assim, de modo geral, nesse período, constatou-se a predominância de atividades isoladas, sendo apenas aqui e ali desenvolvidos por professores de áreas diferentes, de forma mais integrada.

K.: $\quad$ Os planejamentos - eu não me lembro muito bem - você se juntava com os professores da sua área, mas não fazíamos projetos em conjunto. Na verdade, acho que era mais um trabalho individual. Foi uma falha.

C.M.: Na verdade, havia professores que tentavam alinhavar os projetos por área, não tinham reuniões pedagógicas formais, mas tinha muita conversa na sala dos professores. Quando eu cheguei a 'K.' me passou como era a proposta de biologia dentro da escola, como se trabalhava, quais os livros que se adotava, porque se fazia assim, assado, a gente trabalhava com ecologia, que já era um trabalho diferenciado, tinha muitos professores interessados em que os alunos aprendessem.

A.C.: O esquema era bem tradicional mesmo: dar aula e pronto. Se houve professores que trabalharam em conjunto foi porque resolveram por conta própria. Não havia proposta de integração.

E.: $\quad$ Havia aquelas reuniões que a 'I.' falava e todo mundo ouvia, mas a gente conversava na sala dos professores. Eu lembro que numa época tinha um pessoal de manhã, tinha uma constelação de bons professores, tinha a 'L.', o 'N.' , o 'F.', o 'A.', o 'G.', era um pessoal muito bom. Mas não dá para falar em projeto pedagógico. Na verdade a escola era uma escola tradicional, que seguia os ditames da $1^{a}$ Delegacia de Ensino. 
Cada um trabalhava por si. O outro professor de história que tinha lá era um cara que estava ali só prá ganhar dinheiro, não fazia nada, ele dava uns questionários pros alunos fazerem e dava 'C' prá todo mundo. Nós trabalhávamos individualmente, mas às vezes conversávamos entre nós e combinávamos alguma coisa, com os professores que eram mais assim, de fazer uma coisa séria.

Frente ao exposto, pode-se afirmar que a escola não possuía um projeto pedagógico formal, mas atividades isoladas, projetos esporádicos desenvolvidos mediante afinidades entre membros do grupo que partilhavam das mesmas posturas quanto à concepção de ensinar.

De qualquer modo, guardadas as devidas proporções, essas mudanças no pedagógico não passavam despercebidas pelos alunos e, ao longo do tempo, à medida que vão se tornando mais freqüentes, vão colaborando na formação do processo de transformação do Ayres de Moura, uma vez que alteram a visão de escola que sua clientela possuía, alterando também a relação professor-aluno.

Assim, se do ponto de vista da relação entre direção-corpo docente já se torna possível esboçar um quadro geral das dinâmicas presentes na E.E.S.G. Prof. Ayres de Moura, há ainda que pensar a respeito dos alunos e do lugar que ocupavam dentro da escola.

K.: $\quad$ Tinha problema de disciplina, como todo professor tem. Eu tive vários problemas de aluno que não fazia as coisas, chegava atrasado, mas não era uma coisa que deixava a gente desanimado, sem vontade de ir trabalhar. Uma coisa é que o aluno tinha muito respeito pelo professor e o professor tinha respeito pelo aluno. Isso eu senti já desde o começo, e continuou, mais forte ainda, depois do congresso. Não era só por causa da 'I.', porque ela segurava as pontas, mas eu acho que era uma época em que o professor era respeitado. Não como hoje em dia que ninguém nem sabe quem é o professor. Tinha um respeito mútuo, eu acho.

A.C.: $\quad$ Como o maior índice de alunos era à noite, e eram todos trabalhadores, na época não havia essa coisa de vandalismo que tem agora. A escola era conservada. Em relação às outras escolas, acho que lá era menos. Os alunos eram comportados. Eu gostava dos alunos de lá. A gente tem muita saudade daquela época. Você conseguia dar aula, 
você conseguia trabalhar o aluno, você via o aluno crescer. [...] Uma vez, eu me lembro que uma classe começou a sair um pouco mais cedo, coisa de cinco minutos antes, e quando começa aquele barulho no corredor, os outros também vão saindo. Daí a 'I.' começou a gritar naquele pátio e todo mundo começou a voltar. Sabe uma implosão, quando você põe o filme ao contrário? Foi todo mundo prá classe outra vez. Como ela berrou! [risos] Ela era linha dura, realmente.

E.: $\quad$ Um dos fatores pelos quais a escola era boa: os alunos. Naquela época, grande parte deles eram dali do bairro, então eles consideravam a escola deles, entende? Mesmo que no noturno houvesse alunos que viessem de longe e tal, mas era um perfil de aluno... não sei se é da época, a gente não tinha grandes problemas com eles. Tinha o 'S. '17, quer dizer, dissuadia, né? Não tinha essas coisas de depredar a escola. A 'I.' controlava, o 'S.' estava sempre rondando. Então era assim, os alunos tinham medo dele e da 'I.' e também pelo fato de ela ser muito brava, mas ela não era uma pessoa de ficar castigando. O máximo era uma boa 'chamada' no aluno, porque eles morriam de medo dela. Mas não era uma escola como a última na qual eu trabalhei antes de me aposentar ${ }^{18}$ : ali, punir o aluno é a atividade mais importante da escola, só se pensava em castigar o aluno. Mesmo antes do período em que o GEPAM foi diferente, democrático e tal, já vinha com essa herança de não ter castigo como norma principal da escola. No caso da 'I.', ela era mais maternal com os alunos. Eu acredito que até havia o fato de que os professores gostavam dos alunos, pelo menos a maioria. E a 'I.' também. Isso aparece na relação, e os alunos percebem. Havia um bom relacionamento. Isso cria laços de confiança.

C.M.: Como eu era muito jovem, os alunos tinham uma identificação comigo. Eu fiz amizade muito rápido com eles. A gente fazia um pacto e eu conseguia dar aula super-bem, era muito tranqüilo prá mim. Eu percebia que tinham colegas que tinham dificuldades... também havia outros professores que, em função de serem amigos dos alunos não davam aulas, não se preocupavam com conteúdo, ou faziam da sala de aula um lugar de bate-papo e não faziam mais nada.

\footnotetext{
${ }^{17}$ Referindo-se ao único inspetor de alunos que havia na escola, apenas no período noturno. Personagem muito respeitado e temido pelos alunos.

${ }^{18}$ Referindo-se a uma escola estadual na Vila Sônia, zona oeste do município de São Paulo.
} 
A partir das falas acima selecionadas, constata-se que a escola, em termos gerais, não apresentava problemas significativos com relação à disciplina ou de vandalismo, isso devido a alguns fatores: o controle cerrado por parte da assistente de direção e do inspetor de alunos; também pelo fato de, no período em questão, a figura do professor ainda não estar tão desqualificada e, mesmo indiretamente, pela forma de os alunos perceberem uma preocupação, uma atenção dispensada, ainda que de forma autoritária e repressora. Não se pretende, com isso, justificar ou endossar a postura da assistente de direção, mas, antes, destacar que, muitas vezes, a indiferença e o descaso podem ser ainda mais nocivos dentro da prática escolar.

Comparada ao período posterior ao I Congresso, como será visto adiante, a relação aluno-professor nesse momento ainda era bastante distanciada. Mesmo assim, havia, ainda que de modo discreto, identificações entre professores e alunos que iam além de assuntos circunscritos ao conteúdo das matérias trabalhadas na escola, como ilustra o seguinte depoimento:

E.: Havia umas atividades, no tempo anterior ao I Congresso, de vender o jornal 'Movimento' ${ }^{19}$ lá. Eu ia buscar na redação, em Pinheiros, levava pro GEPAM, toda a semana. Eu pegava em consignação. Chegava na escola, dava prá um aluno do centro cívico, que era controlado pela 'I.', e ele vendia esse jornal aos outros alunos disfarçadamente e nem o 'S.' ficava sabendo. Esse jornal era de tremenda oposição à ditadura. Durante muito tempo, ele foi vendido sem a 'I.' saber - 70 jornais por semana. Olha que isso era uma façanha... Até que um dia, o 'S.' descobriu. Contou prá 'I.'. Ela morria de medo. Aí proibiu-se.

Curioso é, também, que a assistente de direção, apesar de proibir atividades explícitas dessa natureza, permitia outras. Os depoimentos também dão a entender que ela identificava alguns dos alunos com tradição militante, sem, por isso, persegui-los.

E.: $\quad$ O B. fez um jornal lá no Ayres e eu dei muito apoio. Ele era da classe do Bolinha, da C. [alunos]. O Bolinha era todo político, e eu lembro que numa eleição, não sei qual, a 'I.' chamou o pessoal do grêmio prá eles fazerem campanha pro Caio Pompeu de

\footnotetext{
${ }^{19}$ Jornal da imprensa alternativa na época.
} 
Toledo, amigo dela. E eles toparam, foram... e fizeram campanha pro Geraldinho! (risos): o PT estava nascendo naquela época... mas a gente começou a ficar amigo de aluno - de verdade - com vocês [referindo-se a mim, e aos alunos em geral, já nos anos 1980, no período próximo ao I Congresso].

Diretor ausente; assistente de direção autoritária; ausência de projeto pedagógico geral; forte teor tradicional - com ênfase no conteúdo a ser transmitido, na disciplina e a obediência -; alunos politizados, com experiência militante, ainda que de forma pontuada dentro do alunado; e um corpo docente diversificado em lento, porém contínuo, processo de mudança: esse era o retrato do Ayres de Moura na virada da década de 1980.

Ao final do ano de 1982, a assistente de direção entrou em férias e era necessário um substituto ocupando seu lugar, o que denota um temor em deixar a escola sob os cuidados exclusivos do diretor, ainda que por um curto período de tempo.

E.: A 'I.' tirou férias, acho que foi no mês de outubro, e falou assim: 'eu vou tirar 15 dias de férias e eu vou permitir que vocês elejam - era bem assim - eu vou permitir que vocês elejam um substituto prá mim'. Aí nós elegemos a 'M.'. Foi quando nós fizemos aquela festa [na casa do professor]. Eu estava em êxtase de felicidade em ver um aluno dançando rock com a diretora, que passa com a diretora por baixo da perna, aquela coisa toda... isso porque a diretora era a 'M.', que tinha 26 anos e você tinha 17: em que escola um aluno dança rock com a diretora?

Esse exemplo deixa claro que a escola já dava indícios de mudança. A crescente identificação por parte de um grupo dentro do corpo docente já começava a dar sinais de uma organização melhor estruturada, aproveitando as oportunidades que a conjuntura oferecia. A assistente de direção apresentando alterações na sua prática, “concedendo” ao grupo de professores que escolhessem um substituto; um grupo entre os professores imprimindo suas marcas - já que a professora escolhida fazia parte do grupo dos professores “novos”, para usar a expressão que perpassa todas as entrevistas e, ainda, uma maior aproximação entre alunos e professores, extrapolando os limites da escola. 


\section{Capítulo II - Marcando posições}

\section{O I Congresso do Ayres de Moura}

“Ela já não era mais a dona da escola.”

(ex-professora)

As transformações ocorridas no cenário político do país e a posse de Franco Montoro por meio do voto direto no governo do Estado de São Paulo, em 1983, tiveram profundo impacto nas escolas de modo geral e, especificamente, dentro do Ayres de Moura.

Tendo sido convidada para trabalhar na secretaria de esportes da nova gestão, a assistente de direção afastou-se da escola, o que foi sentido de forma intensa, uma vez que tudo o que lá ocorria passava necessariamente pelo seu controle.

A.C.: Ela [a assistente de direção] não falou prá gente, nós descobrimos. A 'I.' ia lá só às vezes, à noite, segundo ela, prá dar uma mão pro 'seu D.'.

E.: $\quad$ Ficou o 'seu D.'. Ela tentou até esconder isso da gente, porque na verdade, não queria largar o GEPAM, e a saída da 'I.' deixou um vácuo na escola que foi ocupado pelos professores organizados e também pelos alunos que participavam desse grupo. Havia muitos problemas que a gente acabava resolvendo na sala dos professores, não havia direção na escola.

Além da saída da assistente - importante apenas para a realidade do Ayres de Moura -, outros importantes desdobramentos ocorreram a partir do novo governo, afetando toda a rede estadual.

No sentido de imprimir o teor democrático da gestão peemedebista, oposta à anterior, ainda impregnada do autoritarismo dos quase vinte anos de ditadura militar, a 
secretaria de educação lançou um documento - o Documento Preliminar para Reorientação das Atividades da Secretaria da Educação do Estado de São Paulo ${ }^{20}$ - elaborado por José Mário Pires Azanha, então chefe de gabinete do secretário de educação Paulo de Tarso Santos e professor da Faculdade de Educação da USP. Um dos diversos aspectos importantes a respeito desse documento, destacado nesse estudo, assenta-se em sua intenção primeira, que consistia, em linhas gerais, em fazer um levantamento da situação da rede estadual de ensino a partir das escolas.

E.: $\quad$ Era uma determinação da Secretaria da Educação, todas as escolas tinham que fazer. Porque o Montoro assumiu, era o primeiro governo democrático eleito, e ele colocou um secretário que se eu não me engano, tinha sido o último ministro da Educação do governo Jango. Paulo de Tarso, que era, como o Montoro, um democrata. E lógico, ele precisava retomar, ainda estávamos na ditadura... Imagina, o Maluf saiu e entrou o Montoro. E o Paulo de Tarso mandou esse documento: 'vamos rediscutir'.

Talvez não seja exagero dizer que o documento funcionou também como uma espécie de provocação, uma vez que apontando problemas presentes em toda a rede de ensino - ao mesmo tempo em que não prescrevia nenhum tipo de solução - suscitava a discussão, que, fazendo parte do calendário das escolas, deveriam resultar em levantamento de propostas a serem encaminhadas de volta à secretaria. Em outras palavras, a idéia era ouvir a escolas, a partir do professor.

\begin{abstract}
“Com a preocupação de ampliar a discussão para todos os setores do magistério e ao mesmo tempo propor soluções [...] o Documento $\mathrm{N}^{\circ} 1$ pode ser considerado um divisor de águas na busca da superação dos problemas presentes na escola pública de São Paulo numa perspectiva democrática.” (RIBEIRO, 1992, p.31) ${ }^{21}$
\end{abstract}

Frente à diversidade das escolas, à presença de fortes traços autoritários e também à falta do diálogo - presentes no universo da rede de ensino, fruto de anos de ditadura -, é

\footnotetext{
${ }^{20}$ No cotidiano das escolas, ao longo de toda a rede de ensino, esse documento ficou conhecido simplesmente como "Documento N. ${ }^{\circ}$ 1". A reprodução do documento consta do Anexo II desse trabalho.

${ }^{21}$ RIBEIRO, Sônia. Uma proposta democrática de educação. Nos meandros da máquina administrativa: a implantação e abandono de um projeto. 1992. Dissertação (Mestrado). PUC, São Paulo, 1992.
} 
possível imaginar a magnitude da dificuldade, proporcional à expectativa e ansiedade dos professores, principalmente considerando o Estado de São Paulo como um todo.

Além disso, o fato da análise da realidade educacional do momento bem como o envio de sugestões terem sido agendadas para o dia 19 de maio de 1983, através da Resolução 118, baixada em Diário Oficial, formal e oficialmente constante do calendário escolar $^{22}$, não significa que essas instituições tenham conseguido tal intento de forma plena.

Frente às particularidades de cada unidade escolar, acredita-se que a discussão, o levantamento e o encaminhamento de propostas tenham ocorrido de forma também plural, variando entre escolas que trataram a questão de maneira burocrática (mais um documento solicitado pela secretaria de educação) até aquelas onde a participação de todos foi garantida, com maior ou menor dificuldade.

No caso específico do Ayres de Moura, as aulas foram paralisadas no dia determinado, para que aquele documento fosse discutido. Entretanto, alguns professores, aproveitando a circunstância em que a direção e todos os demais professores estavam presentes, avançaram os limites daquela reunião e lançaram a proposta de um congresso, no qual não apenas professores e direção, mas também alunos e funcionários administrativos discutiriam os problemas referentes à educação em geral, e aqueles que o Ayres de Moura vivia de modo específico. A tônica era “a escola que se tinha e a escola que se queria”.

E.: Houve uma reunião no salão, à tarde, num círculo de carteiras. Quem aprovou o congresso, foram os professores. O 'V.', que era o orientador pedagógico, e o 'seu D.' foram pegos de surpresa. A argumentação do 'A.' foi muito boa. A gente já tinha conversado, eu, o 'A.', o 'N.', a 'K.', a 'C.', a 'A.C.', a 'M.', a 'L.N.', a 'M. L. preta', a 'P.', esse pessoal era mais participante, o grupo antigo era uma minoria. $O$ 'V.' e o 'seu D.' se opuseram, mas como eles eram pessoas queimadas com os professores, a maioria votou a favor. O pessoal [referindo-se aos 'indecisos'] confiava muito mais na gente, porque a escola estava naquela situação de abandono [com a ausência da assistente de direção, a inabilidade do diretor aparecia de forma mais explícita nesse momento]. Os professores estavam revoltados com o 'seu D.'. Qualquer coisa que ele propusesse ali, perderia. E também porque nós éramos muito bem articulados, com experiência no movimento estudantil ou nos partidos clandestinos de esquerda, da

\footnotetext{
${ }^{22}$ Resolução 118. Revista da Faculdade de Educação. São Paulo, jan.jjun. 1984, p. 137.
} 
época da ditadura. Demos uma proposta que também era uma solução, naquele caos: ‘vamos rediscutir a escola?' E aí o 'seu D.' e o 'V.' quando perceberam, quando viram que estavam derrotados, ficaram meio desesperados naquela reunião. Foi aí que eu percebi mais ainda que [o congresso] era muito mais, que era uma intervenção maior do que eu imaginava.

C.M.: Em primeiro lugar, os professores que eram contra não faziam nada. Mas também eles não tinham o poder de 'brecar' e, quando tentavam fazer isso, a gente ia prá briga.

Vencida a proposta e formalmente definida a realização do congresso, restava ainda a questão de como viabilizá-lo, de fato. Os professores envolvidos com o congresso decidiram sensibilizar os alunos à participação por meio da leitura e discussão de textos de diversas naturezas. Alguns extraídos de artigos de jornais e trechos de livros, outros produzidos pelos próprios professores e alunos, alguns deles constantes do Anexo X deste trabalho, além de cartazes e discussões promovidas pelo grêmio estudantil. Muito da organização do congresso deveu-se à participação dos alunos que, no início do processo, foram orientados pelos professores:

E.: $\quad O$ 'A.' foi muito importante nesse passo de discutir a escola naquele momento. Hoje é até fácil, mas naquela época... Ele era orientador do centro cívico, ganhava 18 aulas para isso. A 'I.' tinha posto ele lá porque ela confiava, gostava dele. Ele começou a lançar as idéias, aos alunos, pro 'L.', pro 'J.', através da diretoria do centro cívico. [...] Nós ficamos um mês, um mês e pouco preparando. Tínhamos que fazer apesar da direção ser contra. Cada um trouxe um texto: do Rubem Alves, outro pegou do livro 'Cuidado, Escola!'. A gente combinava ali, na hora: 'hoje na segunda aula, todo mundo vai discutir isso aqui'. O 'A.' como era professor do centro cívico, tinha mais tempo de organizar, mas grande parte foi o 'L.' [presidente do centro cívico] quem organizou.

Dessa forma, o I Congresso da E.E.S.G. Prof. Ayres de Moura aconteceu nos dias 29 e 30 de junho e $1^{\text {o }}$ de julho de 1983 . De maneira simplificada, fez-se, no primeiro dia, um 
levantamento de todos os problemas que a comunidade escolar - professores e alunos identificava. Os tópicos levantados foram organizados de modo a serem discutidos e votados, o que ocorreu no segundo e terceiro dias. Os assuntos abrangiam questões de ordem política, administrativa, pedagógica, entre outras, como será visto mais adiante, quando da análise das propostas aprovadas.

É importante destacar que, no momento das votações, não houve nenhum esquema de representação, nenhuma diferenciação entre professores, alunos e funcionários.

Durante a fase de organização do congresso, havia também a preocupação de que todo esse material obtido no primeiro dia - sujeito à votação nos dois dias subseqüentes refletisse de forma efetiva as inquietações e os desejos do coletivo da escola. Portanto, os alunos foram remanejados da ordem costumeira, da divisão em classes.

No primeiro dia, a discussão ocorreu nas salas de aula, em grupos menores. Cada grupo era composto por alunos de primeiro, segundo e terceiros anos. A participação de um professor, em cada sala, foi facultativa.

Frente à constatação que nem todos os professores e alunos tinham o mesmo grau de compromisso e envolvimento, foram colocados, estrategicamente, professores mais mobilizados em salas mais apáticas, de forma a motivar as discussões. Essa mesma atitude foi tomada do ponto de vista inverso, ou seja, alunos mais participativos e atuantes tiveram presença garantida em salas onde os professores por razões diversas pudessem minar o processo. Essa disposição das pessoas e salas foi elaborada pelo grêmio e por parte do grupo de professores.

E.: $\quad$ Porque tinha gente, uma minoria, que era contra e apostava que aquilo não desse certo. Mas é claro que, onde não podia ter professor comprometido com o congresso, a gente procurou por um aluno, pelo menos. A idéia era: 'deixa os alunos falarem'. Porque às vezes a figura do professor poderia coibir. Teve professor que se sentiu bem e não saiu, quis participar. Na hora que a gente ensinou como era, e começou a funcionar, eu falei na minha sala: 'gente, eu vou deixar vocês discutirem.' E saí. É claro, havia alunos experientes a respeito do funcionamento de uma discussão, em todos os grupos. E deu certo. O 'S.' [inspetor de alunos] ficou perplexo, fez uma declaração depois. Todo mundo nas salas, discutindo, não ficou um aluno no pátio, um aluno no corredor! Aquilo causou um impacto. 
Foi então, dessa forma, que os problemas da escola foram levantados pela comunidade e votados nos dois dias subseqüentes. Entretanto, pode ser questionado - como muitos contrários a toda organização e ao movimento na época argumentaram incansavelmente - em que medida, os alunos - e também professores que não tinham uma posição marcada - não foram levados por um grupo de pessoas a agirem sem saber ao certo o que estavam fazendo? Os depoimentos referentes a essa questão foram claros:

C.M.: Os professores tinham o mesmo tempo prá falar que os alunos. Não existia nenhum privilégio prá professor durante o congresso. O aluno falava, o professor tinha direito de falar também, não tinham regras especiais para professor. Tinha desde aluno novinho, de 15 anos, como tinham senhoras de 40 e poucos anos, do magistério. $O$ grupo de alunos era bastante heterogêneo. Tinha o pessoal do noturno que trabalhava fora, que tinham necessidades, conviç̧ões, quer dizer, não eram alunos facilmente manipuláveis, mesmo que houvesse algum interesse nisso. Eram alunos que tinham militância política, alunos que participavam de comunidades religiosas... Manobrar prá quê? Fazer a cabeça do aluno prá quê, se todo mundo queria melhoria de ensino, uma escola melhor, mais organizada, que os alunos participassem, prá que a escola não virasse uma prisão, para que ela não fosse depredada, que fosse aberta prá comunidade, enfim, o congresso tinha vários objetivos.

K.: A idéia foi da cabeça do 'A.', pode ser. Mas se não tivesse aquele grupo de professores, ele não teria conseguido levar em frente. Um grupo que bancasse tudo aquilo. Não teria avançado. Juntou um grupo com idéias, com vontade de mudar, com vontade de fazer coisas novas e o momento era aquele.

A.C.: Eu acho que não [houve manipulação]. Era muita gente. Eu acredito que [os alunos foram] direcionados. Aluno, por si, não teria as idéias que surgiram ali. Então, direcionados talvez, mas não manipulados, eu acho muito pesado. Nós éramos educadores, conscientes. Essa palavra não pode fazer parte do educador, essas atitudes. Eu acho um crime você manipular uma pessoa. 
Ao mesmo tempo, por parte dos professores idealizadores, o congresso ia além de ações políticas: era também um recurso didático, em si mesmo.

C.M.: Os alunos tinham, às vezes, medidas muito autoritárias. As resoluções dos alunos eram: põe guarda, fecha a escola, expulsa não sei quem, aluno que estiver no corredor sem fazer nada manda prá não sei onde... Se não tivesse às vezes os professores para contra-argumentar, que é justamente o trabalho educativo, as resoluções do congresso seriam muito mais proibitivas. Na verdade, os professores foram grandes mediadores, eles não foram impositivos. Eu participei de tudo e nunca vi nada de manipulação. Muito pelo contrário.

E.: $\quad$ Realmente era uma preocupação que a gente tinha, de não manobrar. Mas é claro que a gente tinha consciência de que nós tínhamos mais experiência. Nós éramos 'macaco velho' do movimento estudantil. Eu me lembro que um dia, eu e o 'N.', acho que o 'A.' também, fizemos uma manobra, de propósito, durante um dos congressos, ou uma assembléia, eu não me lembro, mas foi pedagógico. Foi assim, prá mostrar que eles podiam ser manobrados, e que eles tinham menos experiência. A possibilidade existia. O 'P.', o 'L.', o 'J.' [alunos] ficaram muito 'putos' da vida com a gente. E nós mostramos o que nós tínhamos feito. $O$ 'N.' falou prá eles: 'nós fizemos isso de propósito, prá vocês ficarem espertos nesse sentido.' Mas era uma preocupação. Claro, há pessoas preocupadas em não manipular, e outras não estão ligando muito, existem diferenças. Mas entre esse grupo fortemente atuante de professores, havia um sentimento de levar propostas, de discutir e principalmente de ouvir os alunos. Mesmo porque a gente aprendeu que o aluno às vezes sabe mais que a gente. Depois, quando nós fomos suspensos, os alunos trabalharam sozinhos, tinham aprendido. Foram aprendendo-fazendo. Isso foi uma das coisas mais lindas na minha vida, quando eu vi que funcionava: 'eu não sou mais necessário nesse sentido, as pessoas estão andando por si.’ Mas era tudo, muito pedagógico. Aprendizado. Nós éramos professores de fazer aquilo: de fazer assembléia, de exigir direitos, de argumentar, de reivindicar, de participar de uma forma organizada. Então éramos professor disso também, de cidadania! 
O trajeto traçado de todo esse processo parece levar a crer que seus participantes iam tendo mais clara a magnitude daquilo que estavam construindo no próprio desenrolar dos acontecimentos. Iniciado por alguns professores e alunos, o movimento ganhava força e ritmo próprios, sem controle por esse ou aquele grupo. A escola já não era a mesma e os alunos iam se percebendo como capazes de atuação, por si próprios. Um exemplo disso foi o incidente ocorrido quando a assistente de direção, já afastada, vai à escola numa das noites de votação, 30 de junho de 1983, durante o congresso.

E.: $\quad$ Ela começou a discutir com o 'D.' [aluno] porque ela apareceu lá e começou a ditar regras, como ela costumava, e ele disse que ela tinha que falar três minutos como todo mundo. Imagina, a 'I.'! Aí eu tentei salvar a situação, mas ela ficou brava e foi aquela briga. Então nós fizemos aquele documento dos professores que estavam lá. ${ }^{23}$

K.: $\quad$ Politicamente, eu era assim, muito fraquinha. As coisas estavam na minha cabeça, mas não muito claras. E eu acho que o congresso fez assim - 'bum' - na minha cabeça e me fez pensar melhor. Não conseguia enxergar tudo o que viria depois. E prá mim, foi assim, um impacto, acontecer tudo aquilo. Quando a 'I.' entrou naquela sala, no segundo dia do congresso, eu me senti mal, porque ela entrou dum jeito... foi difícil. Porque a gente tinha respeito pela 'I.'. Eu tive vontade de sair correndo da sala, me enfiar embaixo de algum lugar. Mas depois eu vi que era uma coisa que tinha que ter acontecido. Ela já não era mais a dona da escola.

Assim, as deliberações do congresso, aprovadas pelo voto direto, foram transformadas em um regimento interno que a partir do segundo semestre de 1983 e, independentemente da direção, passou a vigorar dentro da escola. Algumas deliberações puderam entrar em vigor imediatamente após o congresso. Outras não, pois demandavam tempo, trabalho e mobilização, como será visto mais adiante.

\footnotetext{
${ }^{23}$ Página 11 do relatório das resoluções do primeiro congresso, constantes do Anexo III.
} 
Os conflitos, que até então subsistiam, ora mais, ora menos explícitos, vieram à tona de forma definitiva. Haja vista que o primeiro item - Direção - constante da página 4 do documento resultante do congresso ${ }^{24}$ especificava:

“a) Encaminhamento do afastamento do diretor da escola junto aos órgãos competentes (proposta aprovada na plenária do período da manhã);

b) Presença constante do diretor na escola procurando maior integração entre direção e alunos e encaminhando soluções para os problemas da escola (proposta aprovada na plenária do período noturno).”

A partir desse momento - inclusive com a saída da assistente de direção e do único inspetor de alunos, que com ela trabalhava numa relação muito próxima -, os antagonismos tornavam-se cada vez mais acirrados: de um lado, a inabilidade administrativa e pedagógica da direção, apoiado, de forma explícita, por um grupo minoritário de professores; de outro, um grupo de professores, mobilizados e fortalecidos em decorrência dos resultados do congresso, apoiados pela maioria dos alunos, cuja organização ia solidificando-se na medida em que as práticas de discussões iam ocorrendo na escola.

Caracterizando a dinâmica na escola nesse momento, destaca-se também outro grupo de professores que, apesar de não concordar com as transformações da escola - por diversas razões -, não marcavam posição clara, muitas vezes discordando, por meio de críticas pronunciadas em conversas individuais ou mediante comentários com alunos, no espaço reservado de suas salas de aula.

Durante o mês de setembro, alguns alunos, por iniciativa própria, teceram críticas à direção e à situação geral do Ayres de Moura daquele momento - segundo semestre de 1983 -, por meio de cartazes afixados pelo pátio, provocando uma reação por parte do diretor e do coordenador pedagógico:

A.C.: Eu não lembro o teor dos cartazes, que foram parar não sei onde. Os alunos foram chamados e foram suspensos pelo 'seu D.'.

\footnotetext{
${ }^{24}$ Ver Anexo III.
} 
E.: $\quad$ Foi uma coisa dos alunos, assim, 'vamos tentar reconstruir a nossa escola', não tinha nada de radical. $O$ 'V.' e o 'seu D.' foram rasgando os cartazes e jogando no lixo. Uns alunos me falaram e eu fui lá e quebrei o pau com eles. O 'W.' e o 'F.' [alunos] foram suspensos e nós, na sala de professores, falamos que quem dava aula era a gente, e os alunos estavam admitidos [não suspensos] em nossas salas de aula! Nós ignoramos a decisão dele [diretor], prá você ver como ele mandava!

Dessa forma, com a deterioração crescente da relação entre a direção da escola e parte do corpo docente, o ano letivo de 1983 terminou em clima de conflito aberto. A escola funcionou, minimamente, ao longo desse período, devido ao esforço e comprometimento de parte do grupo docente. Houve, inclusive, ainda que não consensualmente entre o grupo de professores mais mobilizados, uma tentativa de trabalho em conjunto com a direção, o que, além de não funcionar, intensificou os conflitos existentes na escola.

E.: $\quad$ A 'I.' tinha saído. Tinham muitos problemas, o 'seu D.' era totalmente omisso, ia embora oito e meia, nove horas da noite e a escola ficava entregue a quem entrava lá, quer dizer, não tinha direção e quem tinha que resolver eram os professores, na sala dos professores. O professor que estava ali resolvia, sabe? Era meio assim. E num desses momentos de briga, a 'M.' resolveu que ficaria como assistente de direção $e$ ela assumiu, assim, ajudar o 'seu D.' Houve uma tentativa de fazer uma certa conciliação, que eu era contra, o 'N.' era contra, mas a 'M.' defendeu então a gente chegou a um acordo. Foi uma tentativa desastrosa, porque o 'seu D.' realmente não era de fazer nada do que ele tinha prometido, a própria 'M.' ficou cheia. Aí eu sei que a coisa ficou tão feia nesse segundo semestre que a gente acabou articulando o pedido da sindicância. Nós fizemos um documento para a $1^{a}$ Delegacia arrolando 49 irregularidades na escola.

No entanto, o que parece ter selado definitivamente a cisão entre direção e a grande maioria da escola, inviabilizando qualquer possibilidade de conciliação, foi um incidente acerca de alterações na grade curricular, elaborada pelos professores da escola e 
encaminhada à $1^{\mathrm{a}} \mathrm{DRECAP}^{25}$, bem como a forma arbitrária com a qual a direção tratou as decisões coletivamente tomadas.

Como parte de um processo mais amplo de redemocratização, e também das inúmeras mudanças que a gestão Montoro propunha no âmbito da Educação no estado de São Paulo, propondo maior autonomia nas escolas, estas deveriam encaminhar, via Delegacia de Ensino, propostas com relação a mudanças na carga horária, inclusão e/ou exclusão de algumas disciplinas, alterando dessa forma, a grade curricular.

E.: $\quad$ A discussão já existia dentro do GEPAM: da grade curricular, de fazer um colegial básico. Aí veio uma resolução da Secretaria de Educação, no segundo semestre de 1983, logo depois do congresso, para que isso fosse feito em todas as escolas. Nós fizemos uma proposta muito discutida, mesmo porque tinha sido assunto discutido $e$ anteriormente votado no congresso. Eu lembro que daí a gente fez essa discussão e a 'Ma.', professora de química, encheu o saco porque ela vinha com aquela conversa de ter que preparar para o vestibular, ela queria aulas de química aos montes, ela queria que fosse como no 'Colégio Bandeirantes', sabe? Levou dias discutindo, tinha que fazer o acordo político com as 'Ma. da vida', eram pessoas atrasadas, teve que parar aula para os alunos discutirem, depois levar para o Conselho [de escola] aprovar... E o 'seu D.' pegou uma proposta que tinha feito com o 'V.', de qualquer jeito, e mandou, ao invés de mandar a nossa, que já estava pronta.

Sendo assim, os professores decidiram ao final de 1983 e início do ano seguinte não ajudar mais nas atividades fora das atribuições que lhe cabiam - elaboração de horário, lista de classes, entre outros - conforme mencionado nos depoimentos: o Ayres de Moura iniciou o ano letivo de 1984 no completo caos.

\footnotetext{
${ }^{25} 1^{\text {a }}$ Delegacia Regional de Ensino da Capital. A reprodução do documento consta do Anexo IV.
} 


\title{
As repercussões do I Congresso
}

\author{
“[...] mas não [...] confundir direitos civis com \\ liberdade política [...], pois, falando de \\ maneira geral, liberdade política significa \\ participar do governo, ou não significa nada."
}

(Hannah Arendt - Da Revolução)

Conforme já mencionado anteriormente, o início do ano letivo de 1984, dentro do Ayres de Moura, foi bastante tumultuado. Além das questões políticas, a desorganização no administrativo da escola contribuía para um ambiente caótico. Sem listas de classes e horário, tudo funcionava em clima de improviso.

Um artigo do jornal Folha de São Paulo, datado de 18 de fevereiro de $1984^{26}$, fornece mais detalhes sobre essa situação. Uma comissão formada por 60 membros professores, alunos, pais e funcionários ${ }^{27}$ - dirigiu-se à Secretaria de Educação, no dia 17, sexta-feira, exigindo mais uma vez o afastamento do diretor da escola.

Embora o então secretário, Paulo de Tarso Santos, não recebesse a comissão do Ayres de Moura, conversou ao telefone com a diretora da $1^{\text {a }}$ Delegacia de Ensino DRECAP1 - Magdalena Ussui, que se comprometeu a visitar pessoalmente a escola na qualidade de membro da comissão da sindicância, anteriormente solicitada pela comunidade escolar. Ainda de acordo com o artigo, teria a diretora sugerido o nome do professor ' $\mathrm{H}$.' como assistente de direção, o que significava uma tentativa de neutralização da mobilização que ocorria na escola, já que tal professor representava os interesses do grupo que se via radicalmente oposto às mudanças que lá ocorriam. Um dos professores que participou desse encontro comentou:

E.: [...] se o 'seu D.' saísse, o 'H.' ficava, porque ele era o sucessor natural, esse era o grande nó. [o diretor havia nomeado esse professor, 'H.’, como assistente de direção] É certo que na secretaria tinha um monte de gente aliada, porque tinham os autênticos do MDB, os deputados, o irmão do 'N.', que já era deputado nessa época,

\footnotetext{
${ }^{26}$ A reprodução do artigo consta do Anexo V.

${ }^{27}$ A participação dos pais nas atividades do Ayres de Moura foi tradicionalmente muito reduzida, dada a idade dos alunos, por se tratar de uma escola de segundo grau.
} 
a gente conseguiu contatos, fomos falar com a Cecília Guaraná ${ }^{28}$... Isso inclusive evitava qualquer retaliação ainda maior prá cima da gente. Eles [referindo-se ao pessoal da $1^{\text {a }}$ Delegacia] estavam apostando no 'H.', porque era aquela cambada de malufistas $^{29}$. Então, nós fizemos essa manifestação [descrita no artigo do jornal Folha de São Paulo], e o chefe de gabinete recebeu a gente no anfiteatro. E eu falei prá ele que nós não podíamos admitir que no momento em que estava acabando a ditadura, um malufista viesse a ser diretor da nossa escola. O Montoro prometia a democracia nas escolas, então como um malufista pode ser diretor? Aí o 'homem' falou: 'qual é o nome dele?' Aí eu falei e eles barraram a nomeação do 'H.'!

Na semana seguinte - 25 de fevereiro de 1984, sábado - foi publicada no Diário Oficial a suspensão, por quinze dias, de três professores da escola. Em resposta à suspensão dos professores e também como reação às medidas arbitrárias tomadas pela direção da escola e pela $1^{\mathrm{a}}$ Delegacia de Ensino, os alunos do Ayres de Moura decidiram não assistir às aulas, permanecendo na escola, em discussão e mobilização, até que os professores suspensos retornassem. Depoimentos de ex-professores ilustram essa passagem:

E.: $\quad$ O 'seu D.’ não tinha coragem de fazer isso [aplicar a suspensão]. Isso foi coisa do 'H.'. Ele estava querendo dar o golpe e virar diretor. Eu não sabia de nada [sobre ter sido suspenso]. Tinha saído no Diário Oficial. Nós estávamos juntos, indo prá escola. Aí, na carona, dentro do carro, o 'N.' me falou: 'você pode ser até preso se falar com aluno’. Eu cheguei lá, tive que pegar uns papéis, entrar com um recurso, dar entrada na minha defesa - nove meses depois, a gente foi anistiado pelo Montoro - mas teve todo um processo. [...] Na hora de ir embora, a gente ia descendo aquela escada, quando os alunos começaram a descer para o pátio. $O$ 'N.' e o 'A.' [os outros dois professores suspensos] me puxaram, e eu ouvia a voz do 'L.' [presidente do centro cívico e um dos membros da liderança entre os alunos], gritando, comunicando aos outros alunos em assembléia o que estava ocorrendo na escola.

\footnotetext{
${ }^{28}$ Coordenadora de Ensino da COGSP - Coordenadoria de Ensino da Região Metropolitana da Grande São Paulo, órgão da Secretaria da Educação do Estado de São Paulo durante a gestão de Franco Montoro.

${ }^{29}$ Referindo-se às pessoas que, de forma mais ou menos acentuada, eram pró-Paulo Maluf, ex-governador do período imediatamente anterior à gestão Montoro, um dos porta-vozes das forças conservadoras do momento, fortemente identificado com a ditadura militar.
} 
Um outro artigo da Folha de São Paulo ${ }^{30}$, datado de 03 de março do mesmo ano, descreve essa mobilização idealizada e conduzida exclusivamente pelos alunos.

A greve dos alunos teve grande importância, tanto no sentido de contribuir para o afastamento do diretor e a subseqüente eleição de uma nova direção que representasse seus interesses, como também ilustrar o processo de autonomia que esse segmento da escola adquiria paulatinamente, por meio da prática cotidiana de discussão e deliberação. Em outras palavras, do exercício da cidadania. Se, no início do processo do I Congresso, que esta pesquisa utiliza como marco, os alunos foram auxiliados e, mesmo muitas vezes, dirigidos pelos professores, a partir desse momento, mostraram-se capazes de decidirem sobre o curso dos acontecimentos por si próprios.

Depoimentos de alunos apontam que esse momento foi bastante desgastante, pois a greve, com atividades diárias na escola, coincidiu com o processo de sindicância que, embora iniciado num período anterior, tornou-se, a partir da manifestação ocorrida na Secretaria de Educação, ostensiva e intensa.

Diariamente, a partir do primeiro dia de suspensão dos professores, três supervisoras diferentes compareciam à escola, fazendo com que os alunos tivessem que iniciar as explicações e as discussões, a cada nova visita, a partir do zero. Além disso, ainda tinham que contar com o boicote de um grupo de professores que, apesar de minoritário, estavam, a seu modo, "gerindo” a escola, como lembrou um ex-aluno:

C.E.R.:[...] Teve aquela estória da chave: o 'C.' [um professor] tinha trocado a fechadura do salão para os alunos não entrarem, porque eram lá as assembléias. Uma das supervisoras foi lá na sala do 'seu D.' - eram três no total - e pegou a chave. Todo mundo entrou, e antes de começar a reunião o 'L.' [aluno, presidente do grêmio] colocou em votação se as supervisoras poderiam participar da reunião ou não. A mulher ficou uma fera e foi aquela briga, uma ficou muito nervosa, foi pro banheiro, começou a passar mal. Algumas professoras contam que carregaram a supervisora. Acho que elas ficavam surpresas porque pensavam encontrar uma escola bagunçada, com uma porção de alunos revoltados. Mas a gente estava organizado. No fim votouse para que elas participarem, para elas se inteirarem do que estava acontecendo. Só que tinham que falar por três minutos, como todo mundo.

\footnotetext{
${ }^{30}$ Ver Anexo VI.
} 
Diversos depoimentos ressaltaram a surpresa das supervisoras, ao conversarem com alunos e constatarem o alto nível de organização e autonomia com que estes se colocavam. Por outro lado, a participação diminuía a cada dia, e muitos alunos, principalmente os do primeiro ano chegaram a mudar de escola, pedindo transferência, pois não tinham a dimensão do que estava ocorrendo na escola. No entanto, a mobilização dos alunos era fato. Chegou-se a adotar - numa época em que não havia uniforme - a camiseta amarela como símbolo “pelas diretas e contra o 'D.'” (referindo-se ao movimento em prol das eleições diretas para presidente conhecido como "Diretas Já”, que estava ocorrendo por todo o país). Uma das atividades dos alunos durante o período de greve foi pintar parte da escola - uma grande escadaria que dava acesso ao prédio principal e também ao pátio - de amarelo. Alunos do período da manhã recolheram o dinheiro - com a ajuda de duas professoras de biologia e, à noite, os alunos - com a ajuda material dos vizinhos (baldes, vassouras, pincéis) - pintaram os muros internos e a escadaria, sob o olhar de policiais da 33a Delegacia de Polícia, chamados pelo diretor da escola, que assistiram a tudo, sem contudo impedir a manifestação.

Do mesmo modo que as supervisoras de ensino, os policiais pouco puderam fazer por não encontrarem motivos que justificassem qualquer tipo de intervenção dada a natureza organizada e pacífica das atividades dos participantes.

Durante esse período, alguns professores e alunos envolvidos mais diretamente com a liderança do movimento passaram a se reunir na casa de um dos professores suspensos, o que ocorria após o término das atividades do período noturno na escola, já que eles não tinham acesso à escola. O objetivo era trocar informações e também traçar diretrizes para as atividades do dia seguinte. O depoimento abaixo ajuda também a perceber a relevância do papel desempenhado pelos alunos ao longo do processo de afastamento do diretor.

E.: $\quad[. .$.$] aí eu voltei prá casa, subindo pelas paredes prá saber o que estava acontecendo.$ Estava tudo acontecendo lá e eu não estava no meio, imagina! Eu ligava lá e não adiantava, porque estavam censurando o telefone, não dava prá falar com ninguém. Aí a 'C.' ligou e falou que vinha prá cá [a casa do professor]. Veio você, o 'L.C.' , o 'L.' [alunos] a 'C.', o 'N.', o 'A.', a 'K.' [professores] ... A gente ficou até quinta-feira fazendo essas reuniões. E decidimos aquela coisa da pintura de amarelo. [...] A gente foi chamado prá depor, cada um num dia. Eles faziam perguntas prá gente se enrolar, que era prá voltar o processo contra nós. Mas aquela reação [dos alunos] a nosso favor 
e contra o 'seu D.', deu toda a diferença. A atitude dos alunos deu um baque naquela gente [o pessoal da Delegacia de Ensino]. Então, eu lembro que a sindicância mudou.

A confluência de fatores - a organização crescente do movimento, a pressão frente à Delegacia de Ensino e à Secretaria de Educação, somada à incipiente oposição feita ao grupo mobilizado, bem como o caos administrativo e uma série de irregularidades confirmadas pela sindicância instaurada na escola - culminou no afastamento formal do diretor. De acordo com registros em ata $^{31}$ e segundo a legislação vigente, em maio de 1984, reuniu-se o Conselho de Escola que seria responsável pela eleição de um diretor substituto para a E.E.S.G. Prof. Ayres de Moura.

O processo de escolha do novo corpo diretivo, entretanto, requer um olhar mais aproximado.

Uma das indagações do presente estudo, a partir desse ponto, consistiu em descobrir a real extensão da efetiva participação - sobretudo dos alunos, já que numericamente eram muito superiores aos professores - num momento de deliberação tão importante, tomando o processo como um todo.

Para tanto, tomou-se como referencial teórico, as reflexões de Arendt (1988) ${ }^{32}$ acerca do conceito de revolução. Não que com isso advogue-se pela proposição de que houvesse acontecido, dentro dos muros do Ayres de Moura, uma revolução na acepção clássica do termo ${ }^{33}$.

É a questão da liberdade política, da participação e representação que esse estudo pretende compreender melhor.

De acordo com a autora, o conceito de revolução vai além da idéia de mudança e pressupõe dois momentos distintos: a libertação e a constituição da liberdade.

Entenda-se, dentro do modelo proposto por Arendt, que libertação é o momento de ruptura com a estrutura vigente - por exemplo, através da refutação do abuso do poder, seja de um tirano ou um grupo específico, dentro do corpo social.

\footnotetext{
${ }^{31}$ Ver Anexo VII.

${ }^{32}$ ARENDT, Hannah. Da revolução. São Paulo: Ática; Universidade de Brasília, 1988.

33 Embora autores como Félix Guattari tenham falado em "revolução molecular”, tal discussão não será considerada, uma vez que essa questão não faz parte do escopo desse estudo.
} 
Entretanto, essa ruptura muitas das vezes implica uma simples troca de grupos detentores dos mecanismos de controle social. O abuso de poder ficaria, dessa forma, controlado, sem jamais ser distribuído. Ao restante da população ficaria apenas a garantia de alguns direitos, e isso muito pouco tem a ver com o segundo momento, o da constituição da liberdade política.

Remontando à Grécia antiga, Arendt (1988) nos diz que a polis

[...] foi entendida como uma forma de organização política em que os cidadãos viviam juntos em condições de não-mando, sem uma distinção entre governantes e governados. Essa noção de não-mando era expressa pela palavra isonomia, cuja característica mais importante, entre as formas de governo enumeradas pelos antigos, era de que a noção de mando estava inteiramente ausente dela. [...] Essa igualdade perante a lei que a palavra isonomia sugeria, não era a igualdade de condição [...] mas a igualdade dos que fazem parte do corpo de pares. (p. 24)

Pretende-se ressaltar dessa passagem o fato da isonomia ser um atributo da polis e não dos indivíduos. No caso, a igualdade era uma criação - artificial -, que deslocava os homens de sua desigualdade, sendo preservadas e respeitadas suas diferenças. E a relevância disso consiste em ter claro que a liberdade política, como entendida nesse estudo, significa participar do governo, da condução das coisas públicas. A constituição da liberdade deve garantir não apenas a instituição de um espaço onde os indivíduos possam ter garantidos os meios de participarem e decidirem efetivamente sobre tudo aquilo que lhes é comum, bem como terem respeitadas suas diferenças de toda e qualquer ordem e, nesses termos, suas desigualdades. Significa também entender que a liberdade assim constituída seja ir além da ditadura da maioria: "não se trata da garantia da maioria, mas garantir o poder de cada um" (ARENDT, 1988, p. 203).

Feitas as devidas considerações acima expostas, retomamos a questão: como os alunos da Ayres de Moura, que desde o início haviam participado ativamente do processo, teriam lugar garantido no espaço deliberativo se o órgão responsável pela escolha de um novo diretor era o Conselho de Escola, que, no período em questão, era composto por 35 membros, sendo que, dentre esses, apenas 2 eram alunos?

Como garantir que o afastamento do antigo diretor - momento da ruptura, da libertação - não redundasse apenas na substituição daquele corpo diretivo por outro, alijando 
a grande maioria dos alunos da participação direta, frustrando assim o segundo momento - a constituição da liberdade?

Buscou-se entender, então, se os alunos não teriam sido excluídos, a partir daquele momento, seja explicitamente ou de forma velada, mediante a concessão da garantia de participar limitadamente via representatividade, ou ainda, através de escolhas entre alternativas criadas por outras pessoas que não eles mesmos ${ }^{34}$.

Um trecho da ata da eleição do diretor substituto, constante do Anexo VII deste trabalho, esclarece que, mesmo frente às imposições legais, a participação dos alunos foi garantida:

\begin{abstract}
"Finalizando foi-nos solicitado para registrar em ata, segundo informação verbal do professor 'A.' e testemunhado por todos os presentes que, anteriormente a presente eleição, foi efetuada consulta ao corpo discente deste estabelecimento para indicação da professora 'A.C.' responder pela direção da escola com o seguinte resultado: 542 votantes, 491 a favor, 39 contra, 07 nulos e 05 em branco.”
\end{abstract}

Depoimentos de professores também contribuíram para entender melhor como isso aconteceu:

E.: $\quad$ Naquela época, todos os professores faziam parte do conselho, não tinha eleição e a escola estava reduzida pela situação. Tinha menos alunos, menos professores, foi um momento, inclusive, em que muitos deixaram a escola. A 'A.C.' foi eleita pelo Conselho de Escola, que era formado por uns trinta e poucos professores, dois alunos votantes e dois observadores $^{35}$. Foram escolhidos alunos representantes da manhã e da noite... nós usamos a lei. Só que esse conselho, ou a maioria desses professores, assumiram... como os alunos tinham pouca representação, nós assumimos essa chapa [Profa. 'A.C.' para diretora e Profa. 'M.’ para assistente]. Várias vezes aconteceu isso, de a gente assumir o que os alunos decidissem. A maioria se comprometia a fazer. Houve referendos no GEPAM. Então, essa chapa, articulada pela maioria dos professores e pela maioria dos alunos, foi referendada e foi prá conselho, como proposta, na verdade. E para que ficasse bem sacramentado, houve um plebiscito na

\footnotetext{
${ }^{34}$ Por exemplo, votando entre isto ou aquilo, sem que eles próprios compusessem a lista das opções a serem escolhidas.

${ }^{35}$ Os grifos foram colocados para salientar a desproporção entre professores e alunos que legalmente havia no Conselho de Escola.
} 
escola. Houve uma votação maciça na chapa, e os únicos que votaram contra, foi uma classe inteira, que haviam combinado porque não queriam perder a 'M.' como professora.

A.C.: Para ser diretor é preciso ter habilitação: pedagogia com habilitação em administração escolar. Isso é obrigatório. Tinha bastante gente com habilitação [porém] foi indicado o meu nome, o 'N.' insistiu muito. Eu nunca pretendi ser diretora, eu não sabia ser diretora de jeito nenhum. Não sabia o que era prontuário de aluno: 'como é que eu vou ser diretora desse negócio?' Aí o 'N.' disse: 'nós ajudamos! Todo mundo vai ajudar. Não é você: você está representando a gente. Vai todo mundo dirigir isso daqui' Então tá bom (rindo). Legalmente, era o Conselho de Escola que indicava [o novo diretor]. O que a gente fez de diferente no Ayres foi consultar os alunos.

É desse modo que, a partir de 07 de maio de 1984, toda a comunidade escolar ${ }^{36}$, que as professoras 'A.C.' e 'M.' representavam, assume a direção do Ayres de Moura, dando início a um processo de auto-gestão que duraria aproximadamente dez anos.

\footnotetext{
${ }^{36}$ A expressão "comunidade escolar" aqui tem seu significado limitado a todos aqueles - professores, funcionários e alunos - envolvidos com a escola. No Capítulo IV, o conceito de comunidade será abordado mais detalhadamente.
} 


\title{
Capítulo III - Entre o político e o pedagógico
}

\section{O processo de auto-gestão}

\begin{abstract}
"Era uma escola em assembléia permanente. É claro, havia pessoas que se interessavam mais, $e$ outras menos. Desde a Grécia Antiga é assim."
\end{abstract}

(ex-professor)

Não seria difícil imaginar as dificuldades pelas quais o coletivo da escola passou, tendo dela se apropriado. Das entrevistas, identificou-se, de modo geral, uma atmosfera de euforia e muito trabalho. Apesar da oposição - ainda presente na escola - ser minoritária, a existência de conflitos e problemas foi constante. Mesmo assim, o despreparo acerca das questões legais e administrativas, e as dificuldades em geral, pareciam não inviabilizar o processo de auto-gestão que lá se instaurava:

A.C.: Eu acho que foi o maior desafio da minha vida, porque eu não sabia realmente de nada. Eu não sabia nem o que é que tinha que ter num prontuário de um aluno. Aí eu pedi socorro prá $1^{a}$ Delegacia. Os professores queriam ajudar, mas sabiam tanto quanto eu: nada! E a gente queria fazer tudo certinho. Felizmente eu encontrei supervisoras que me ajudaram muito. Após a reunião de posse, os supervisores foram embora. Aí, íamos começar uma reunião pedagógica, nossa, para definir diretrizes da escola. Foi então que o 'E.' e a 'Cl.’ [professores] resolveram se pegar. E eu pensei: 'O que é que eu faço? Eu mando parar? Eu mando calar a boca? Eu deixo continuar? Deus, me ilumina!' Eu só sei que eles continuaram brigando e eu deixei eles brigarem - tudo o que tiver que resolver, todas as picuinhas, nós vamos ter que resolver aqui e agora. Vamos botar prá fora... até que acalmaram.

O depoimento acima aponta que a discussão - algumas vezes, inclusive, exaltada -, era, agora oficialmente, uma prática dentro do Ayres de Moura. Isso não pretende justificar 
qualquer tipo de manifestação desrespeitosa, ou mesmo violenta. Numa outra direção, advoga-se a importância de a escola ter sido, em todas as suas instâncias, um fórum de discussão que garantia a manifestação de idéias, posicionamentos divergentes bem como a resolução de conflitos. Além disso, salientar, apesar da obviedade, a necessidade da desconfiança frente a situações onde consenso parece dominar, seja na escola como um todo, seja numa sala de aula, ou mesmo numa reunião de professores ou alunos. Perigosamente confundida com “ordem”, o que pode ocorrer numa situação dessas é uma sutil relação de coerção, travestida de democracia. Sob esse ângulo, talvez seja possível entender a dificuldade que um certo número de professores e alunos tinha em compreender o processo que ali ocorria, muitos inclusive deixando a escola nesse período, uma vez que percebiam as transformações como “bagunça”, desorganização, desrespeito à autoridade.

Havia, mesmo durante a preparação do I Congresso, diversos professores que relutavam a tomar posição, argumentando que "não se envolviam em política”. No caso específico desses professores, jamais saberemos se tal argumento era recurso de forma a evitar comprometimentos e assim mantê-los numa aparente e ilusória neutralidade, ou se eles realmente acreditavam possível reduzir a pedagogia e a didática à técnicas e métodos desprovidos de quaisquer traços políticos. De qualquer modo, considerações acerca do que o presente estudo entende por político fazem-se necessárias. Para tanto, parte de três definições distintas:

"O conceito de Política, entendida como forma de atividade ou de práxis humana, está estreitamente ligado ao poder. [...] O poder político pertence à categoria do poder do homem sobre outro homem [e] esta relação de poder é expressa de mil maneiras, onde se reconhecem fórmulas típicas de linguagem política: como relação entre governantes e governados, entre soberano e súditos, entre Estado e cidadãos, entre autoridade e obediência, etc.” (BOBBIO, 1986, p.954-955) ${ }^{37}$

"Política é o processo social através do qual o poder coletivo é gerado, organizado, distribuído e usado nos sistemas sociais. Na maioria das sociedades, é organizada sobretudo em torno da instituição do ESTADO. [...] Embora seja associado com mais freqüência a instituições de governo nos níveis internacional, nacional, regional e comunitário, o conceito de política pode ser aplicado a virtualmente todos os sistemas sociais nos quais o poder representa papel importante. Podemos, por conseguinte, fazer perguntas sobre a política da vida familiar e da sexualidade, a política do escritório, a política universitária ou mesmo a política da arte e da música. Este último

\footnotetext{
${ }^{37}$ POLÍTICA. In: BOBBIO, Norberto; MATTEUCCI, Nicola; GIANFRANCO, Pasquino. Dicionário de política. 5 ed. São Paulo: Imprensa Oficial SP; Universidade de Brasília, 1986.
} 
argumento tem importância especial porque chama atenção para o fato de que todos os sistemas sociais têm uma ESTRUTURA DE PODER.”(JOHNSON, 1997, p.178) ${ }^{38}$

\begin{abstract}
"Em sentido muito geral, do ponto de vista científico, pode-se definir como políticos os processos, atos ou instituições que definem polemicamente uma ordem vinculadora da convivência que realize o bem público. [...] O que caracteriza a política ou o político não é um desses elementos, mas o equilíbrio de todos eles - bem público, caráter polêmico ou conflituoso dos atos que visam a sua realização e intervenção de agências de poder. A concorrência desses três elementos dão ao político um caráter fluido. Podem ser políticos assuntos de natureza diversa, em diferentes circunstâncias históricas.” (AGESTA, 1987, p. 922)
\end{abstract}

Não obstante à dificuldade de uma conceituação, é possível perceber a presença de três elementos estreitamente ligados entre si, e é exatamente isso o que o presente estudo entende por político: relações de "poder” dentro de um “coletivo”, e embora matizado, tais relações são necessariamente “conflituosas”, porque abarcam interesses divergentes.

No sentido de compreender melhor a dinâmica das relações de poder, sua imaterialidade e a inerente imprevisibilidade que elas abarcam, recorreu-se também às idéias desenvolvidas por Hannah Arendt (2004) ${ }^{40}$, especificamente ao se referir à ação.

Ao discorrer sobre ao conceito de vita activa, a autora levanta três pontos fundamentais: o labor - correspondente a quaisquer atividades humanas ligadas ao processo biológico do corpo humano; o trabalho - que seria a artificialidade da vida, tudo aquilo que seja distinto do ambiente natural, pois criado pelo homem e ligado à materialidade das coisas; e a ação - atividade por excelência exercida única e exclusivamente entre os homens, sem a mediação das coisas ou da matéria. Por transcender as condições materiais pelas quais a vida foi dada ao homem e também por estar livre das amarras do labor e do trabalho, a ação é a condição de toda e qualquer atividade política, sempre presente na teia de relações produzidas pelos homens porque vivem juntos. E onde houver homens reunidos, haverá ação e teremos inevitavelmente relações de poder.

\footnotetext{
${ }^{38}$ POLÍTICA. In: JOHNSON, Allan G. Dicionário de sociologia: guia prático da linguagem sociológica. Rio de Janeiro: Jorge Zahar, 1997.

${ }^{39}$ POLÍTICA. AGESTA, Luis Sánchez. In: SILVA, Benedicto (Coord.). Dicionário de ciências sociais. Rio de Janeiro: Fundação Getúlio Vargas, 1986.

${ }^{40}$ ARENDT, Hannah. A condição humana. 10ª ed. Rio de Janeiro: Forense, 2004.
} 
[...] o poder não pode ser armazenado e mantido em reserva para casos de emergência, como os instrumentos da violência: só existe em sua efetivação. Se não é efetivado, perde-se [...]. [...] o poder é sempre, como diríamos hoje, um potencial de poder, não uma entidade mutável, mensurável e confiável como a força. [...] devido a esta peculiaridade, que possui em comum com todas as potencialidades que podem ser efetivadas mas nunca inteiramente materializadas, o poder tem espantoso grau de independência de fatores materiais [...]. [...] o único fator material indispensável para a geração do poder é a convivência entre os homens. Estes só retém poder quando vivem tão próximos uns aos outros que as potencialidades da ação estão sempre presentes. (ARENDT, 2004, p. 212-213)

Nesse sentido, o argumento postulado pelos professores que insistiam em afirmar que não se envolviam em política, chama a atenção uma vez que mesmo a opção pelo não envolvimento implica necessariamente uma posição - já que estamos inexoravelmente imersos em relações de poder que são inerentes ao convívio humano e, por isso, políticas.

Igualmente, esse estudo pretende mostrar a inviabilidade da eliminação do caráter político da esfera didático-pedagógica de uma unidade escolar, seja ela qual for. Nesse capítulo, procura-se mostrar, entre outras coisas, como as mudanças políticas refletiam no âmbito pedagógico da escola do mesmo modo em que todas as alterações pedagógicas eram também políticas. Mencionados por todos os entrevistados, a implantação da sala ambiente na escola e a participação dos alunos nos conselhos de classe, que se realizavam a cada bimestre do ano letivo, foram destacados e aqui analisados. Outros ainda foram selecionados, como será visto em detalhes, mais adiante.

De qualquer modo, no Ayres de Moura desse momento - o de apropriação da escola pela comunidade escolar -, muito havia a ser feito e as condições não eram as mais favoráveis, sem contar a enorme carga de trabalho extra que a comunidade escolar teve que abraçar.

A.C.: Aí foi aquela coisa: vamos, todo mundo, trabalhar. Eram sábados, domingos, todo mundo carpindo, era mutirão disso, mutirão daquilo, enquanto um conserta fechadura, o outro raspa o chão, o outro troca vidro, aquelas coisas todas...

E. Aí nós fizemos uma tomada de posse, que foi aquela limpeza da escola. 


\section{Vandalismo}

Esse envolvimento dos alunos e professores - nunca todos, obviamente - provocou desdobramentos importantes. Destaca-se, primeiramente, a questão do vandalismo, aqui analisado em dois momentos distintos.

Conforme já visto, no período anterior ao I Congresso, casos de depredação do espaço escolar eram esporádicos, dado que a escola era constante e rigorosamente vigiada. Situação bastante diferente foi o período em que ela entrou em processo de franco abandono, com a saída da assistente de direção e do inspetor de alunos.

No período posterior, quando a direção passou a representar o interesse do coletivo, os problemas dessa natureza voltam a diminuir, mesmo não sendo adotado nenhum mecanismo repressor como, por exemplo, inspetores rondando pela escola. Ao contrário, registre-se que os portões da escola ficavam, nesse período, constantemente abertos, podendo o aluno entrar na escola quando lhe aprouvesse. Inclusive, dada a falta de quaisquer outros espaços de convívio social no bairro, o Ayres de Moura era freqüentado por muitos adolescentes que não eram, necessariamente, estudantes ${ }^{41}$.

Isso, em alguns momentos, trouxe problemas sérios à escola - com relação à segurança, por exemplo. No entanto, o que se pretende registrar é que, não obstante a falta de vigilância, os casos de vandalismo eram infreqüentes, mesmo tendo os alunos todas as oportunidades para práticas dessa ordem. Os professores também foram interpelados com relação a esse ponto:

K.: $\quad$ Eu acho que é porque todos estavam envolvidos com a escola. Isso foi uma coisa bonita. E todos cuidavam da escola. Pena que nós não conseguimos manter isso. Mas eu acho que os alunos estavam envolvidos, os professores que realmente participaram de tudo estavam envolvidos. Todos cuidavam da escola. Então, não tinha problema de ter o portão aberto, de não ter funcionário na escola.

\footnotetext{
${ }^{41}$ No início dos anos 1990, um dos professores entrevistados lembrou-se que dois alunos do $3^{\circ}$ Colegial, praticamente aprovados, decidem não fazer nenhuma das avaliações do quarto bimestre. Questionados por alguns professores sobre a razão de tal comportamento, os alunos responderam que dada a impossibilidade de continuarem seus estudos, terminado o segundo grau, preferiam ser reprovados e continuarem na escola a não ter nenhuma ocupação à noite, após chegarem a casa, do trabalho.
} 
E.: $\quad$ Essa participação... esse grupo de professores que acabou dirigindo a escola, de certa forma, como um colegiado, também envolvia os alunos. Eles eram sócios. Não todos, apesar de que todos eram chamados, mas é claro que nem todos participavam com a mesma intensidade, mas havia uma participação dos alunos; o congresso; uma série de instâncias, os alunos eram consultados. Havia um mecanismo, que era o conselho de representantes de classe, que era uma forma rápida de consulta. Assim, quando fosse usar uma verba, por exemplo, qualquer coisa que precisasse decidir, os alunos participavam, discutiam, então, se sentiam donos da escola. Não depredavam. Claro que sempre há casos. No tempo em que colocaram os bebedouros, tinha gente que arrebentava o cano. Nós falávamos: 'gente, quem é que vocês estão atacando? É água gelada prá todo mundo no verão’ E a maioria não entendia porque alguns destruíam. Mas até isso era didático, de mostrar o que é um bem público, mas é lógico que a pessoa que faz isso sempre faz escondido, e a escola não tinha uma fiscalização, não tinha nem inspetor de alunos no tempo em que a escola foi democrática. Não tinha dinheiro prá isso.

A.C.: Eram uma média de quatro a cinco [funcionários responsáveis pela limpeza], mas sempre um em licença, era uma briga muito grande. Ninguém dava conta de varrer tudo aquilo. Quando você é dono do seu espaço, você é responsável por ele, você mantém organizado, limpo. Agora, quando não é de ninguém... E depois a gente começou a discutir com os alunos que eles não poderiam quebrar, porque se eles quebrassem um vidro, nós teríamos que usar o dinheiro da biblioteca prá comprar o vidro, porque não tinha verba. Então raramente tinha um vidro quebrado.

O exemplo abaixo ilustra como a direção da escola relacionava-se de forma muito próxima dos alunos e de como os problemas poderiam, em certos casos, vir a ser resolvidos:

A.C.: A gente começou a tentar descobrir quem estava pichando a escola. Eu me lembro que um dia, uma parede apareceu toda riscada e... eu acho que às vezes eu tenho alguma intuição. O menino conversava muito comigo, eu gostava dele. Cheguei prá ele, à noite, no pátio, e falei assim: 'puxa vida, você, quem diria, heim! Isso é papel de um aluno como você?’ E não é que tinha realmente sido ele? Que coincidência! Ele 
ficou apavorado: 'ai 'A.C.', como eu estou me sentindo mal!' E eu disse: 'olha, você tem 24 horas prá limpar essa parede.' 'Ai, 'A.C.', eu trabalho amanhã!' 'Não interessa, ou você limpa isso em 24 horas, ou seu prontuário vai direto prá delegacia.' Não deu outra: o aluno faltou no trabalho, no dia seguinte estava tudo limpo. Às vezes, algum aluno chegava até mim porque algum professor tinha visto, $e$ eu falava duro com ele. Mas esse caso eu nunca me esqueço.

A seleção dessas falas busca colocar em destaque a relação entre a participação direta - ainda que matizada - dos alunos nos processos de decisão e gerência da escola e a diminuição considerável de problemas de depredação e vandalismo decorrentes do compromisso estabelecido entre aluno e espaço escolar. Destaca-se também a presença da diretora, no pátio, conversando, relacionando-se com os alunos, diminuindo as distâncias entre esses dois segmentos, tão comum nas escolas.

Dessa forma, pode-se dizer que a baixa incidência de vandalismo do período anterior às transformações ocorridas dentro da escola devia-se ao grande esforço no sentido de vigilância e controle por parte da direção autoritária e de intensa fiscalização de "S."42, que ininterruptamente rondava os corredores dos prédios ${ }^{43}$.

No segundo momento, entretanto, a hipótese assenta-se no fato do aluno identificar-se com a escola, sentir-se parte dela, por participar da condução dos acontecimentos que lá ocorriam.

Outra hipótese - a de que talvez o novo funcionamento do Ayres de Moura fosse uma forma mais sutil e sofisticada de controle dos alunos comparada ao período anterior, sendo, portanto desnecessária a presença de dispositivos controladores mais visíveis e grosseiros - não se sustenta, principalmente diante da participação efetiva e direta de todos os alunos nas decisões referentes ao cotidiano da escola, em outras palavras, no exercício consciente do poder.

\footnotetext{
${ }^{42}$ Inspetor de alunos que se desligou da escola no mesmo período em que "I.”, assistente de direção do período anterior, sai da escola para trabalhar na Secretaria de Esportes do Estado, na gestão Montoro.

${ }^{43} \mathrm{Um}$ dos alunos que estudou na escola, nesse período, se lembra que as grades dos portões eram às vezes recobertas por óleo automotivo queimado ou mesmo graxa, de modo a evitar que os alunos pulassem, impossibilitando-os de entrar ou sair do prédio fora dos horários determinados pela direção, os únicos em que os portões ficavam abertos.
} 
Os excertos abaixo selecionados - itens aprovados no I ou no V Congressos do Ayres de Moura $^{44}$ (1981 e 1989, respectivamente) - ajudam a ilustrar a relação existente entre os alunos e o espaço escolar:

"O aluno deverá ter a liberdade de poder assistir outras aulas em seu horário vago.” (I Congresso - item I.2.g)

"Os alunos terão a liberdade de sair da aula no momento em que desejarem." (I Congresso - item I.2.h)

"No período de circulação dos alunos (entrada, intervalo e troca de salas ${ }^{45}$ ), ninguém poderá permanecer sentado nas escadas.” (V Congresso - item 1.1.c)

"O uso da biblioteca será exclusivo para estudo e pesquisa sendo vedado o seu uso para outros fins.” (V Congresso - item 4.1.c)

"Deverá ser feito um cadastro das motos dos alunos, professores e funcionários que usam o estacionamento do pátio. Pessoas que não são da escola não poderão entrar na escola com motos.” (V Congresso - item 5.1)

"O salão deverá ser usado exclusivamente para sala de estudo, de reuniões e projeção de 'slides'.” (V Congresso - item 5.4.a);

“A mesa de pingue-pongue deverá ficar na sala do Grêmio ou no pátio, sendo guardada no banheiro. As pessoas que a tirarem de lá deverão deixar seus nomes se responsabilizando por trazê-la de volta.” (V Congresso - item 5.4.d);

"O Grêmio organizará os alunos que trabalham com grafite, determinando os espaços a serem trabalhados e desenvolvendo campanha contra pichações.” (V Congresso - item 4.3.c);

Este último item, em particular, exemplifica como determinados problemas eram apropriados pela escola, transformados em objeto de estudo e trabalhados em sala de aula:

\footnotetext{
44 Houve cinco congressos ao longo de todo o processo de auto-gestão. Não foi possível obter nenhum documento referente às deliberações aprovadas nos II, III e IV congressos. Talvez tenham sido extraviados ou não chegaram a ser impressos. As deliberações do I e V Congressos constam dos Anexo III e VIII, respectivamente.

${ }^{45}$ Referindo-se à circulação de grande número de alunos pelos prédios, por conta das salas-ambientes. Seja devido à ocorrência de aulas-vaga ou pelo fato de alguns decidirem não assistir determinada aula, a permanência de alunos sentados pelas escadarias dos prédios prejudicava a circulação dos colegas, fazendo com que eles mesmos, dessa forma, resolvessem o problema, discutindo-o naquele congresso.
} 
C.E.R.: Eu me lembro que houve um período em que a escola começou a ficar muito pichada. Naquela época, o 'B.' [professor de educação artística] estava dando aulas de grafitagem. Foi feita uma campanha, com votação entre os melhores desenhos e tudo o mais, para ver quais iriam para os muros e paredes da escola. Fizemos isso [a grafitagem] ao longo de alguns sábados e foi um grande evento. Muitos alunos passavam por lá prá ver, prá conversar, passar a tarde, parecia mais um clube. Os grafites foram atualizados de vez em quando. A escola ficou sem ser pichada por um bom tempo...

Além disso, em momentos como, por exemplo, reposições de greve, tão freqüentes no período em questão, onde atividades geralmente aconteciam aos sábados, mesmo sem o controle da freqüência dos alunos, a presença era - ainda que consideravelmente menor, comparada ao período em que as aulas ocorriam normalmente -, bastante grande.

Acredita-se, portanto que, por determinado período, pelo menos entre a maioria dos alunos, se conseguiu re-qualificar a idéia de bem público, deslocando-o daquilo que "não é de ninguém” - infelizmente tão arraigada em nossa cultura -, para aquilo que “é de todos”. Isso, sem dúvida, dado o sentimento do pertencer à escola na mesma medida em que a escola ao aluno pertencia.

\section{Sala-ambiente}

Durante o processo das entrevistas, foi perguntado aos ex-professores o que, pedagogicamente falando, para eles foi mais significativo em termos de mudanças na escola, a partir do momento e que a comunidade do Ayres passa a geri-la. Um dos itens lembrados unanimemente foi a implantação da sala-ambiente, que também foi acontecendo num processo, fruto de muita discussões, tentativas, erros e reformulações.

A.C.: Algumas medidas foram implantadas até a gente chegar na sala-ambiente. A gente começou a botar em prática as coisas mais simples. Por exemplo, quem vai dar aula na sexta-feira? Os professores mais severos, que não faltam. Não deu dois meses estavam todos os alunos lá, em peso, às sextas. Ninguém acredita, porque até hoje é 
difícil dar aula nas escolas às sextas-feiras. [O sistema de salas-ambientes] funcionou meio que precariamente em termos de material, porque a gente não tinha material prá distribuir por todas as salas, mas foi assim um trabalho perfeito. Eu tenho a impressão que foi até junho, organizando. Precisou fazer horário adequado à salaambiente - o mais difícil da sala-ambiente é o horário. Eram uns 100 professores. $O$ que foi interessante é que a economia de tempo foi de quase $60 \%$ maior do que quando o professor mudava de sala. E todos os alunos entravam em aula. Só aquele grupinho que nunca entrava, mas daí a gente conversava com eles: 'Você não vai entrar em aula hoje? É importante. Que aula vocês têm agora? Vamos lá, gente.' Eu que ficava como inspetora de alunos. [risos] Se você imaginar que em 84, nós implantamos a sala-ambiente!

Os depoimentos revelam o caráter experimental do processo da implantação da salaambiente no Ayres de Moura. Algumas condições naturalmente favoreceram, já que entre outros, o espaço físico da escola assim permitia. Muito da experiência foi baseada em informações esparsas, vindas de outras escolas. Havia ainda dificuldades de ordem material e, além disso, a idéia não era consenso entre o corpo docente como um todo, por razões que, conforme as entrevistas mostraram, variavam desde a convicção pedagógica de que o sistema não era adequado, até o boicote da proposta - seja pela questão do não entendimento ou até mesmo resistência frente ao desconhecido. Ainda assim, a despeito dos problemas enfrentados, o sistema foi implantado.

E.: $\quad$ A sala-ambiente foi uma coisa que nós aprendemos de ver em filmes (rindo). A nossa experiência foi a seguinte: informação de uma amiga minha, que havia visitado uma escola pública na Inglaterra e explicou prá gente como funcionava. A 'Cle.' que era professora da escola, tinha trabalhado numa escola em Santo Amaro que tinha essa experiência e trouxe algumas informações importantes sobre o funcionamento. A 'A.C.' também tinha ido prá Inglaterra e tinha visto uma escola lá, e trouxe outras informações. Eu lembro que muitos professores que antes de implantar a salaambiente eram contra, depois, não queriam outra vida. Porque realmente, quando se fala em sala-ambiente, pensa-se só na tecnologia, aquela coisa cheia de aparelhos, globos que descem do céu... a sala-ambiente tem outras coisas importantes, ela 
trabalha com a autonomia do aluno, com a variedade de ambientes mesmo, de poder circular. Ao mesmo tempo você pode ter material nos armários, alguma coisa que facilite a tarefa de ensinar.

K.: $\quad$ Muitas outras coisas aconteceram, mas a sala-ambiente foi uma das melhores. Você podia organizar a sua sala, preparar sua aula na sua sala, tinha o material ali... tudo! E o aluno, quando chegava, falava: 'puxa, a aula já toda preparada!' E você não tinha que ficar carregando nada de uma sala para outra. Muitos professores tinham uma sala bem montada. Você entrava naquela sala e sabia do que era [de qual disciplina se tratava]. No começo, os alunos ficaram perdidos porque eles não sabiam prá onde ir: era aquela confusão de aluno passando prá lá e prá cá... foi complicado. Mas era bom porque o aluno tinha que ser responsável. E aquele que não estava a fim, acabava matando aula mesmo, ou chegando atrasado, o aluno não era vigiado. Ele tinha que saber se entrava na aula ou não. Toda a responsabilidade era do aluno e muitos tinham entendido muito bem o que era a sala-ambiente.

C.M.: A sala-ambiente era bárbara porque facilitava o trabalho da gente, você tinha um lugar onde podia colocar os seus livros, o material, além da aula render mais, os materiais estavam todos ali na frente, você montava a sua biblioteca, tem a questão da limpeza, da estética que é importante, você está num lugar limpo, bonito, bem pintado, que não seja agressivo, que as pessoas se sintam bem prá aprender. Agora, dava trabalho. Eu me lembro que às vezes eu ficava na escola o dia inteiro. Não era o meu horário de trabalho, mas eu ficava, arrumava a sala, pintava, organizava, coletava material pros alunos fazerem as oficinas. Eu acho que a maioria [dos professores] entendeu [a proposta da sala-ambiente]. Tem um grupo preguiçoso que não vai fazer nunca, tem um grupo que se faz de desentendido porque não interessa, ele quer dar a aulinha dele e ir embora. As pessoas fazem opções. Mesmo no grupo que não participava, havia pessoas muito inteligentes. Simplesmente tem pessoas que não querem fazer, ideologicamente não concordam, acham que aquela aulinha bem certinha é a melhor. 
E.: $\quad$ Nós trabalhávamos nas condições dadas, que era uma escola pública. A gente não podia obrigar a pôr em prática uma coisa que muitos nem podiam porque não tinham condições de formação prá isso. Então, nas condições que existiam a gente procurava fazer o melhor. A escola era uma escola em movimento, vinham novas idéias boas que a gente ia incorporando. Não é que a gente tinha tudo pronto, uma tese de doutorado prontinha prá gente chegar lá e implementar. Aquilo era a história em movimento, a gente foi fazendo.

A implantação da sala-ambiente na escola trouxe, ainda, dois aspectos dignos de um exame mais minucioso. O primeiro deles diz respeito à autonomia do aluno. Já foi mencionada a não existência de mecanismos coercitivos que obrigavam a presença do aluno em sala de aula, tais como advertências e suspensões. É fato a presença da diretora entre os alunos, no pátio, dialogando, de forma ora mais ora menos enérgica, variando de acordo com a natureza do problema. Entretanto, a preocupação central era muito mais a conscientização do aluno pela importância de freqüentar as aulas do que a garantia da sua presença em sala via imposição e/ou punição.

Com o passar do tempo, a maior incidência desse problema ocorria entre os alunos do primeiro ano, já que, recém-egressos de escolas que funcionavam de forma diferente, tinham dificuldade em administrar sua autonomia. A adaptação nem sempre era tranqüila. De qualquer modo, o problema do não-comparecimento dos alunos às aulas nunca foi, em termos gerais, significativos dentro do Ayres de Moura, tampouco maiores se comparados à média das escolas em geral.

Além disso, é importante também entender o alcance da proposta da sala-ambiente dentro do Ayres de Moura. Anteriormente ao processo de implantação, durante o período em que eram feitas as discussões sobre o que era e como viabilizar o funcionamento desse sistema, informações a respeito, de diversos lugares, chegavam até a escola, conforme já mencionado anteriormente na fala de um dos ex-professores.

Uma dessas informações foi um documento, assinado pela direção e dirigido aos professores, alunos, inspetores e serventes de outra escola pública de segundo grau da zona oeste da capital $^{46}$. Esse documento objetivava informar, a cada um dos segmentos daquela escola, sobre as mudanças pela qual ela passaria a partir de determinada data, quando o

\footnotetext{
${ }^{46}$ A reprodução do documento, na íntegra, consta do Anexo IX.
} 
sistema de salas-ambientes lá passasse a funcionar ${ }^{47}$. Cabem aqui algumas considerações sobre tal documento, a partir da seleção de alguns trechos.

“Aos professores: (página 1 do documento)

9b) Não permitir que o aluno entre em aula após o segundo sinal, a fim de que ele se conscientize o mais rapidamente possível do funcionamento do sistema.

9c) Evitar deixar o aluno permanecer só na sala, ocasião em que ocorrem as 'depredações'.”

“Aos alunos: (página 2 do documento)

5) O professor impedirá sua entrada após o segundo sinal.”

“6) Sua permanência fora da sala de aula poderá significar uma advertência em sua caderneta. Três advertências poderão causar-lhe uma suspensão. Cuidado.”

“Aos inspetores de alunos: (página 2 do documento)

3) Levar todo aluno que esteja fora da sala de aula após o segundo sinal, até a direção ou pessoa encarregada, para anotar advertência na caderneta.

5) Verificar, de vez em quando, se não há aluno escondido na toalete.”

Não é objetivo de este trabalho tecer nenhum tipo de crítica com relações às medidas adotadas pela escola em questão, mesmo porque tal intento não procederia, visto que as condições que desencadearam o processo lá ocorrido são desconhecidas. A intenção é, mesmo sob o risco de incorrer na obviedade, mostrar que o sistema de salas-ambientes, por si só, não significa muita coisa e nem é sinônimo de inovação pedagógica. A singularidade que cada escola apresenta não pode ser ignorada.

Os grifos das passagens selecionadas (que não constam do original do documento) nos ajudam a refletir sobre como algo que num primeiro momento possa parecer um avanço - a utilização do uso de salas-ambientes numa escola pública -, pode abarcar concepções de educação bastante tradicionais, através de relações entre proibição

\footnotetext{
${ }^{47}$ É difícil precisar quando o sistema começa a funcionar e também como foi o processo de implantação nessa escola, já que o documento não apresenta data e, nem mesmo o professor que gentilmente forneceu o documento, recorda-se de como ele chegou até o Ayres de Moura. O que se sabe é que as mudanças naquela escola ocorreram no mesmo período (primeira metade da década de 1980) e que um dos professores do Ayres pediu o documento emprestado de modo a contribuir nas discussões que lá vinham sendo feitas.
} 
e conscientização (“aos professores" - item 9b), punição ("aos alunos" - itens 5 e 6) e vigilância (“aos inspetores” - item 5).

Diferenças marcantes não só em questões referentes à sala-ambiente, como em outros aspectos como, por exemplo, confiança e respeito à autonomia e à maturidade do aluno, são encontradas ao analisar alguns itens das propostas aprovadas, no I e no V Congressos do Ayres de Moura, como ilustram os trechos abaixo selecionados:

"Em caso de perda de prova, os professores não deverão exigir qualquer tipo de atestado do aluno para que este possa fazer a prova. Contudo, se ao aluno, após sua falta na data marcada, continuar faltando outros dias, a aplicação de nova prova será decidida entre o professor e a classe.” (I Congresso - item I.2.f)

"Duas cópias da chave de cada sala de aula deverão ficar com dois representantes de cada classe [alunos]; uma cópia ficará na secretaria da escola (medida de caráter provisório até a instalação das salas-ambientes).” (I Congresso - item III.b)

O sistema de sala-ambiente, especificamente no caso do Ayres de Moura, foi uma mudança discutida, debatida e implantada de forma que a qualidade das aulas lá oferecidas, do ponto de vista pedagógico, pudesse ocorrer sem que isso prejudicasse ou interferisse nos já conquistados avanços políticos. Propunha-se que a sala-ambiente fosse muito mais do que a simples inversão de quem se movimentava pelos corredores do prédio. Tal estrutura, da forma como lá foi montada, permitia também criar condições para que os alunos pudessem desenvolver sua autonomia, decidindo ou não - por si próprios - a respeito de comparecer ou não às aulas. Os depoimentos também mostraram que tal proposta, ao longo do processo de auto-gestão sempre apresentou problemas, dada a postura de alguns professores frente à salaambiente. Entretanto, mesmo especificamente a esse respeito, há ainda algumas considerações a serem feitas.

Muitas vezes, por questões de horário ou de espaço físico, uma mesma sala tinha que ser divida entre dois professores. Nesses casos, poderia ocorrer que o modo como um professor montava sua sala influenciava aquele que com ele repartia o espaço, afetando de certo modo a sua prática profissional. Além disso, à medida que os alunos circulam por espaços diferenciados, comparavam e muitas vezes questionavam determinados professores, 
forçando em alguns casos - às vezes mesmo de forma conflituosa - estes a alterarem sua maneira de ensinar.

A.C.: O que é uma sala-ambiente? Prá que serve? O que muda? Muda a facilidade para o professor de trabalhar: você não vai prá lá e prá cá carregando um monte de atlas, dicionários etc. Na sala-ambiente, qualquer atividade que você queira fazer, você tem tudo ali, em mãos: seus mapas, seu jornal mural, tela para projetar slides, tudo isso é importante para uma aula. Então, isso facilita o seu trabalho e cria possibilidades de você viajar mais durante a aula, o que não acontece quando você tem que ir de uma sala prá outra. Você está no seu espaço, você sente mais liberdade, você sabe onde suas coisas estão guardadas, então isso facilita o seu trabalho. E facilitando o seu trabalho, você tem outro tipo de relação com o aluno. Então, não é simplesmente o aluno se deslocar e o professor não.

E.: $\quad$ Mesmo o professor sendo bom ajuda a ele ser melhor. Ajuda também o professor que não tem tanta prática, não que ele seja ruim. Eu vi no GEPAM muito professores que não tinham uma formação muito boa, mas eles se contaminaram daquele espírito $e$ eles queriam fazer também. Até porque os alunos cobravam. Os alunos cobravam: 'porque que uns fazem assim e você não faz?' Então ficava meio constrangedor a pessoa não buscar. É claro que milagres não havia. Muita gente continuou a mesma porcaria de sempre, mas eu acho que as condições favoreciam mudanças.

Em outras palavras, a existência de salas-ambientes numa escola não quer dizer necessariamente que o projeto pedagógico da escola tem como um de seus elementos constitutivos o exercício da cidadania, no que diga respeito à liberdade e à capacidade de decisão. Durante os dez anos de gestão analisados dentro da escola, sempre houve a presença de professores considerados ruins pela comunidade escolar, isto sendo não raras vezes, fonte de conflitos, ainda acentuados quando o professor era efetivo podendo dessa forma, pelo respaldo da lei, permanecer da escola pelo tempo e com a carga horária que desejasse.

Muitos desses professores acreditavam, por exemplo, resolver as questões pedagógicas que se apresentavam através da disposição das cadeiras em sua sala de aula, como se a disposição do mobiliário fosse, por si só, capaz de propiciar relações mais ou 
menos democráticas numa sala de aula. Conforme lembrou um ex-professor, havia uma piada corrente na época, entre um grupo de professores da escola: “o professor 'fulano' é democrático porque as carteiras na sala dele estão em círculo!”

Devido a esse e outros motivos, projetos pedagógicos individuais ou mesmo políticas educacionais mais abrangentes pedem muita cautela, para que suas aplicações não fiquem restritas ao nível das aparências.

\section{Conselho de classe e conselho de escola}

À medida que a nova gestão do Ayres de Moura se configurava, as práticas de discussão e decisão coletiva não apenas continuavam, mas também iam se sofisticando mediante as necessidades encontradas pela comunidade escolar :

E.: $\quad$ Era uma escola em assembléia permanente, durante anos. Sempre estávamos fazendo reuniões, consultas e referendos. Foram criados mecanismos de consulta rápida. Um deles era os dois representantes de sala, que eram convocados, num zás-trás, prá qualquer tipo de coisa: levar uma mensagem, perguntar alguma coisa prá classe, o que é que eles achavam prá poder tomar uma decisão. A diretora, o conselho de escola e o grêmio podiam convocar uma reunião a qualquer hora. Isso foi sendo construído. É claro que havia pessoas que se interessam mais e outras menos, uns tem mais poder de convencimento do que os outros. Desde a Grécia Antiga é assim.

O que foi sendo criado, a partir de maio de 1984 no Ayres de Moura, e que a distinguia das demais escolas da rede estadual eram exatamente o Conselho de Representantes de Classe - CRC, “órgão deliberativo dos alunos e consultivo em relação às demais instâncias da Escola”48 - e o Professor Coordenador de Classe, já que o Conselho de Escola e o Grêmio Estudantil existiam, pelo menos em tese, nas escolas em geral.

\footnotetext{
${ }^{48}$ Ver item 1.5.a das propostas aprovadas do V Congresso do E.E.S.G. Prof. Ayres de Moura, constantes do Anexo VIII.
} 
Cada classe possuía de um a três alunos representantes, eleitos entre os seus pares. O número de representantes por sala parece ter variado ao longo dos dez anos analisados. Os representantes funcionavam como um canal por onde informações, consultas e deliberações eram feitas, quando uma assembléia que envolvesse toda a escola não fosse viável, ao mesmo tempo em que garantia que a comunicação e as decisões passassem por todos aqueles que faziam parte da comunidade escolar.

O Professor Coordenador de Classe tinha como função, entre outras, servir como mediador entre determinada classe a qual representasse e as demais instâncias, funcionando também como uma espécie de orientador, auxiliando em questões de diversas ordens problemas entre os alunos e demais professores, questões disciplinares, organizações de festas, excursões ou manifestações, para citar apenas alguns exemplos, evitando assim que o Conselho de Escola fosse convocado a todo instante.

Entretanto, além desses mecanismos de que a escola dispunha, outro também lembrado de forma unânime pelos professores entrevistados foi a participação dos alunos no conselho de classe, que acontecia após terem sido efetuadas as avaliações e o fechamento das notas, ao final de cada bimestre.

A.C.: Foi uma das decisões do congresso. A proposta inicial era que se fizesse o conselho de classe com a classe toda, mas demorava muito, a gente acabava perdendo muitas aulas. Nós fizemos, mas não deu certo. É impossível fazer conselho assim. Normalmente nós fazíamos num sábado, havia vezes em que ficávamos até 3 horas da manhã, uma coisa maluca. Só no Ayres mesmo! [risos] Bem, não deu certo, e agora, como é que a gente faz? Já tinha o coordenador da classe [um professor, eleito pelos alunos]. Vamos também eleger três ou cinco alunos. Parece que três alunos tinham direito a voto, uma coisa assim. Aí foi aquele trabalho de conscientização com os alunos, porque era importante participar do conselho. Então, a composição do conselho de classe era a seguinte: todos os professores, um professor representante da classe, e os alunos representantes da classe.

E.: $\quad$ O aluno começou a participar no conselho de classe quando a 'A.C.' assumiu. Tinha gente que achava isso uma coisa terrível. E, que eu saiba, isso nunca ultrapassou os limites do GEPAM, porque inclusive, quando a 'A.C.' fez uma reunião com 60 diretores da $1^{a}$ Delegacia, ela sugeriu que os alunos participassem dos conselhos de 
classe, e ela quase foi linchada porque as pessoas não aceitavam isso. Nessa última escola que eu dei aula antes de me aposentar, se você falar numa coisa dessas, tem gente que se sente ofendida. Lá os alunos participam para 'anotar' [grifo do professor] o que os professores falam e assim, morrendo de medo, acuados. No GEPAM não, nós fizemos várias experiências. Às vezes, participava a classe inteira, se quisesse. Mas a gente viu que não era produtivo. Mas foi essa experiência que, inclusive, moralizou o conselho.

A.C.: Eu acho que em termos pedagógicos esse foi o maior avanço nosso. Quando eu cheguei no 'A.' ${ }^{49}$, fui pensando: 'agora eu vou abafar, né?' Nossa, quase apanhei: 'Como?' - diziam os professores - 'é o único momento que nós temos prá discutir e você ainda vai colocar o aluno?' E eu disse: 'Escuta, mas você está discutindo o quê? Você está discutindo a vida do aluno, não a sua.' Mas não foi possível. Fiquei um ano lá e saí de lá sem conseguir. E isso foi quando? Em 91. Acharam um absurdo. E a gente fazia isso desde 84... Já fui questionada que, como eu era diretora, poderia ter imposto essa mudança na escola, mas se você impõe, não funciona. (A.C.)

As informações fornecidas por meio dos relatos acima suscitaram outras questões. Afinal, pedagogicamente falando, quais são as implicações da participação dos alunos nos conselhos de classe? Por que tal procedimento não era visto positivamente entre alguns dos professores?

A.C.: Em que se resumia o conselho quando era só entre os professores? 'Ah, o Joãozinho é um vagabundo, não faz nada o tempo todo...' Então, era vagabundo, era mau caráter, era folgado, só isso que saía no conselho. Nunca se questionou: 'e você professor? O que você fez prá melhorar a vagabundagem dele?' Ninguém falava: 'esse aluno, está melhorando muito. Ele tinha tais dificuldades, nós trabalhamos com tais dificuldades.' Não, o aluno tinha dificuldades e continuava com elas, porque ele era um vagabundo. Aí, quando a gente mudou, era olho no olho - aluno, professor,

\footnotetext{
${ }^{49}$ Referindo-se à escola na qual foi diretora por um ano. A diretora eleita havia assumido o Ayres de Moura como substituta, já que o antigo diretor havia sido afastado e não exonerado. Por conta de questões burocráticas quanto à pontuação e remoção presentes no processo de efetivação, teve que escolher outra escola, afastando-se do Ayres por um ano, retornando posteriormente na condição de diretora efetiva.
} 
direção, todo mundo ali. Cria-se um clima muito sério. Mudou totalmente o discurso: 'o aluno fulano tem dificuldade na redação, ele tem dificuldade nisso, só que ele não apresentou os trabalhos'. Ninguém mais era vagabundo, ninguém mais era malcaráter, mudou tudo. Depois, na aula seguinte, o professor coordenador se comprometia a passar, junto com os alunos que estavam presentes, toda a discussão que havia sido feita, para o restante da classe.

Essa mudança ocorrida na escola, ou seja, a inclusão dos alunos de forma realmente participativa nos conselhos de classes, a cada final de bimestre, é mais um exemplo de como as práticas dos professores e alunos estavam sempre expostas, sujeitas a comentários e críticas, o que nem sempre era tranqüilo, já que, muitas vezes, era fonte de conflitos: o conselho era um momento a mais, entre outros, em que os indivíduos eram forçados a refletir acerca de suas posições. Aparentemente tão afastado da sala de aula, o conselho de classe era mais um instrumento a serviço do ensino-aprendizagem o que, entre outras características, possibilitava uma apreensão mais dilatada do significado de currículo, tanto para os professores como para os alunos.

Frente à constatação de que, mesmo no auge do período de auto-gestão, sempre houve, ainda que em minoria, professores e alunos que não compartilhavam do mesmo envolvimento com a escola e que, em contrapartida, educadores comprometidos, mesmo no período anterior, dentro de esquemas tradicionais e autoritários, já desenvolviam um trabalho diferenciado, questionou-se, entre os ex-professores entrevistados, em que medida as mudanças de cunho estritamente político contribuíram para um avanço nas esferas do didático e do pedagógico daquela escola. As falas seguintes remetem a essa questão:

C.M.: [Com relação às mudanças políticas] eu acho que concretizava tudo aquilo que a gente queria fazer e não conseguia porque não tinha melhores condições de trabalho. A escola ficou mais organizada, a biblioteca começou a funcionar, a gente conseguia organizar melhor essas saídas educacionais da escola. Você não tinha ninguém lutando contra a metodologia que a gente queria implantar. Tudo isso era um facilitador para concretizar a metodologia que a gente acreditava. Então, mudou sim. A escola ficou mais bonita, tem a questão da limpeza, da estética que é importante, você está num lugar limpo, bonito, que não seja agressivo, que as pessoas se sintam 
bem prá aprender, o jardim foi refeito, tudo isso melhorou muito. Antes existiam pessoas idealistas, com vontade de fazer, fazendo já, mas com dificuldade em fazer. Agora... se eu ensinava melhor antes ou depois? Eu acho que se aproveitava melhor. Rendia mais. Você conseguia fazer o que você queria fazer. Eu ia para a quadra prá dar aula de biologia, eu ia pro parque do outro lado, antes não conseguia fazer isso. Você ficava engessado, ficava naquele modelo de 40 ou 50 minutos, entra em sala, sai de sala e você não consegue fazer nada.

A.C.: $\quad$ Eu acho que o que mais muda, é o pacto que foi feito entre professor e aluno. $\mathrm{Na}$ verdade, quando você levanta a mão e diz: 'eu quero isso', você está fazendo parte daquilo, você está responsável por aquilo, você está decidindo por aquilo. Então você tem que cumprir e cumprir bem. Então, eu acho que a gente conseguiu desenvolver essa idéia pros alunos. Você é responsável porque você votou, você escolheu. Eu acho que o aluno se sente dono da escola e isso é bom, pedagogicamente. A gente não pode confundir metodologia - como eu dou a aula - com o que está por trás dessa metodologia, que é o pedagógico, que é muito mais amplo do que a metodologia. Essa cumplicidade que passa a haver favorece o trabalho do professor. E o professor que trabalha mais feliz, trabalha melhor. Muitos professores mudaram bastante. Mudaram, porque você não tem mais como ser autoritário. Houve muitas medidas que influenciaram diretamente no pedagógico. Por exemplo, o uso coletivo do material [didático] - os alunos não poderiam comprar 11 livros. Nós tínhamos os livros na sala de aula, então eles não compravam, mas tinham, isso também foi bastante importante. A sala-ambiente, conselho de escola com participação de aluno, isso tudo está acontecendo agora, em 2000/2002, e nós fizemos isso em $84 . .$.

E.: $\quad$ Eu acho que você pode fazer um trabalho bem feito dentro de esquemas tradicionais que dão mais trabalho e limitam o trabalho. Se você tem sala-ambiente ou condições mais favoráveis, direção dentro de um projeto mais avançado de ensino, ajuda. Você pega, por exemplo, o 'B.' [professor de educação artística]. Ele tinha uma série de idéias, que, sem a 'A.C.' dar apoio, como é que ele ia fazer? Ele tinha uns quatro ambientes em que ele trabalhava: uma sala convencional prá fazer trabalhos de artes plásticas, uma sala e um palco prá fazer teatro e um laboratório adaptado prá ele montar as instalações. Se ele estivesse numa escola tradicional e atrasada como era 
essa última que eu fiquei, ele provavelmente não faria nada disso, porque a diretora ia boicotar o trabalho dele. Há também o fato de o aluno pressionar: tinha professor que rebolava prá procurar fazer melhor. Muita gente melhorou de medo, dos alunos cobrarem, medo de ser exposto. É lógico que às vezes muita gente tinha raiva da gente porque se eles não fizessem direito, eles não podiam se esconder. Não era aquela escola burocrática, aquela repartição pública. Tinha que trabalhar mesmo porque o aluno exigia, o que eu acho plenamente democrático, a cobrança é democrática. $O$ aluno tem direito de cobrar aulas boas porque o funcionário público que está dando aula lá está sendo pago com o dinheiro público prá fazer um serviço bem feito. Se não está contente, vai brigar com o governo, vai fazer greve, vai fazer alguma coisa...

Além dos dois pontos acima destacados, outro - aparentemente desvinculado por completo da dinâmica interna do Ayres de Moura - também contribuiu para o entendimento das relações existentes entre o político e o pedagógico.

As repercussões dos acontecimentos dentro da escola provocavam maior ou menor interesse pela escola tanto por parte dos alunos, ao ingressarem em escola de segundo grau, como também por professores que, ao escolherem escolas para lecionarem, procuravam ou evitavam o Ayres mediante suas concepções frente à educação, dada a fama da escola, seja entre o bairro, seja na $1^{\text {a }}$ Delegacia de Ensino.

A.C.: $\quad$ Eu me lembro da primeira reunião de diretores que eu participei na $1^{a}$ Delegacia de Ensino. Eu falava de onde era e as pessoas comentavam: 'ah, ela que é daquela escola dos petistas!' [rindo].

C.E.R.: O pessoal do Pio Telles [referindo-se à E.E.P.G. Pio Telles Peixoto, vizinha ao Ayres de Moura] costumava falar: 'a greve está lá na China e o pessoal do Ayres já parou’.

E.: Quando o 'seu D.' foi afastado, a 'A.C.' ficou como substituta. Durante muitos anos, ela foi substituta do 'seu D.'. Quando ela se efetivou, escolheu outra escola, porque não tinha vaga. Ela ficou um ano fora do GEPAM. E quando teve escolha de novo, os 
diretores da $1^{a}$ Delegacia combinaram que ninguém escolheria o GEPAM: eles não eram loucos! [risos] Ninguém queria encrenca.

Dessa forma, as características que os membros da comunidade escolar imprimiram ao Ayres contribuíram para a "seleção natural”, como foi chamado - com uma certa dose de humor - por alguns dos professores. Interpretado às vezes de forma preconceituosa, jocosa, mas também por força de interesses genuínos, o Ayres de Moura, por muitos anos, atraiu professores que buscavam formas alternativas de ensinar. Isso foi muitas vezes fonte de conflitos, frustrações, mas sem dúvida alguma, contribuiu para o enriquecimento e a diversidade das práticas dentro da escola.

Sintetizando, os exemplos utilizados - implantação de salas-ambientes e participação dos alunos nos conselhos de classe - introduzidos a partir de mudanças na esfera política, influenciaram de forma profunda no pedagógico, o que nos mostra a impossibilidade da dissociação entre um e outro.

\section{Questões didático-pedagógicas e currículo}

"Sabemos que os conteúdos e as formas de abordagem, decididas num primeiro momento, sofrerão constantes modificações, mas que não se chegará a um ideal, pois considero que o ideal é exatamente a mudança constante."

(ex-professor)

"Há necessidade da formação de uma Comissão, cujos integrantes estejam dispostos a trabalhar num só sentido; melhoria do Ensino. Esta Comissão teria a responsabilidade de defender os interesses do aluno, do professor e do Ensino. [...] Que seja decretado o fim do autoritarismo por parte de alguns professores. Acabar com esse negócio de: 'Eu sei mais, tenho diplomas, cursos, etc.', e sim fazer uma junção aluno-professor, para juntos discutirem uma possível reforma no Ensino. [...] Quanto à estrutura do Ensino, sua mudança ficaria a critério de professores bem experientes na área, juntamente com as idéias sugeridas pelos alunos. Seria fundamental a implantação de outra matéria, no caso a sociologia, que se encarregasse da formação do aluno, como um ser social, conscientizá-lo dos seus direitos e deveres, não só como alunos, mas também como homem. Sendo assim, os alunos teriam mais motivação quanto ao Ensino e não teriam a Escola com simples distribuidora de diplomas. Parte desses problemas pode ser solucionada 
dentro da própria Escola, basta que alunos e professores se proponham a trabalhar num esforço mútuo.” (Josuel Ribeiro da Silva [aluno do primeiro ano] $-\mathrm{n}^{\circ} 21-1^{\circ} \mathrm{L}-$ junho/1983).

\begin{abstract}
"Nós professores, pela nossa formação, dificilmente perguntamos se o conteúdo de nosso curso é algo que pode despertar no aluno o interesse pelo aprendizado, se esse conteúdo tem, no mínimo, a possibilidade de despertar no aluno o interesse pela compreensão do mundo que o cerca, se, no convívio diário com o aluno, que é intermediado pelo conteúdo, estamos possibilitando ao aluno descobrir que é importante a compreensão do mundo para poder mudá-lo. Os alunos, pela estruturação da escola, por comodismo e/ou por receio do autoritarismo não questionam o conteúdo de seus cursos, e quando o fazem, é sempre de forma utilitarista, 'para que serve essa matéria?’. É preciso que se descubra como fazer para que alunos e professores, atuando conjuntamente, determinem qual o conteúdo de cada uma das disciplinas e a forma (não simplesmente a metodologia) como esses conteúdos devem ser abordados. [...] Qualquer texto sério de Educação considera que o aprendizado de todos os ramos do conhecimento humano é fundamental para a boa formação de um indivíduo, isto qualquer professor sabe. O que talvez passe despercebido é que os alunos também acham isso, sem terem jamais lido qualquer texto sobre Educação.”(Nelson Frateschi Filho - Professor de Física) ${ }^{50}$
\end{abstract}

Através da análise desse documento e de outros referentes à preparação do I Congresso, em 1983, podemos encontrar idéias bastante afinadas com as inquietações do momento, no que diz respeito à educação num âmbito maior, mostrando, entre outros, que o crônico problema do descompasso entre o que se pensa e se produz na universidade, e o que acontece nas salas de aula das escolas públicas, apresenta exceções, ainda que pontuadas.

É possível perceber que a preocupação dos alunos e professores naquele momento, ia além do problema da escola possuir uma direção omissa e autoritária. Questões acerca do currículo, tais como a compartimentalização do conhecimento, vestibular, avaliação, o autoritarismo das relações dentro da escola, a ineficácia dos conteúdos de determinadas disciplinas oferecidas pela escola - na maioria das vezes desconectadas da realidade dos alunos -, eram alguns dos temas presentes em todos os documentos utilizados durante a preparação do I Congresso, contemplados nas discussões e votações.

O documento acima citado traduz muito do clima da preparação daquele congresso e os grifos procuram destacar que a escola devia ser mais que “distribuidora de diplomas”; que

\footnotetext{
${ }^{50}$ Excertos de um dos textos de sensibilização utilizados no período preparatório do I Congresso, realizado em junho 1983. Este documento em especial foi produzido conjuntamente por um aluno e um professor, um dos poucos assinados. Muitos outros foram retirados de trechos de livros e artigos de jornais. Seu conteúdo, na íntegra, além de todos demais obtidos, através de doação de ex-professores, constam do Anexo X desse trabalho. Os grifos não são do original, feitos aqui para destacar alguns aspectos discutidos mais adiante.
} 
alunos, opinando, e aliados à experiência dos docentes, poderiam alcançar soluções para seus problemas dentro da própria escola.

Quanto ao conteúdo das disciplinas, estes deveriam ultrapassar os limites imediatos do utilitarismo, uma vez que o conhecimento implicava na compreensão do mundo visando sua transformação.

Tais idéias obviamente não eram consenso na escola, mas era opinião corrente entre a maioria que promovia o I Congresso, em 1983.

A discussão suscitada por documentos e textos de natureza similar ao do exemplo acima utilizado, foi transformada em proposta, e, após discussão, voto e aprovação, transformou-se em estratégias, constantes do item II - medidas relacionadas à questão curricular e didático-pedagógica - do regimento fruto daquele congresso ${ }^{51}$. Entre elas, alguns exemplos:

“- Reestruturação do curso do magistério;” (item II.1.a)

“- Inclusão do curso Magistério no período noturno;” (item II.1.b)

“- Reformulação total do curso de segundo grau como vem sendo oferecido (divisão nas duas últimas séries em 'Exatas', 'Biológicas' e 'Humanas') e criação do curso básico de segundo grau.” (item II.1.c)

A partir desse ponto, buscou-se compreender melhor as alterações que professores e alunos propunham, já que havia, entre diversos outros obstáculos, a questão legal. Um dos professores esclarece:

E.: $\quad$ Uma das propostas mais discutidas, era que a gente fizesse um colegial básico. Nós não passamos por cima da lei. Havia coisas que os alunos propunham ao congresso que... lógico, a gente discutia com eles: 'tem coisa que a gente não pode passar por cima da constituição' (risos) mas tudo acabava sendo pedagógico. Lembra que eu falei prá você do Montoro? A decisão da mudança da grade curricular foi também uma determinação da delegacia de ensino, da secretaria da educação. Isso na época, foi uma revolução! E a escola passa a ter algumas possibilidades de mudança. Várias

\footnotetext{
${ }^{51}$ Reprodução do documento no Anexo III.
} 
escolas tinham essa proposta [ser contra a divisão entre 'Exatas', 'Biológicas' e [Humanas'] naquela época. A diferença é que nós tínhamos uma discussão acumulada, de acabar com esse lixo ${ }^{52}$, esse resto da ditadura. A gente propôs entrar filosofia, por exemplo. OSPB não saiu. Por quê? Porque era federal. Então deixava uma aulinha só, entende? Na criação do curso magistério noturno, por exemplo, foi diferente, mas levou tempos. Teve abaixo assinado, um monte de gente se mobilizou prá ter esse curso: é o Ayres de Moura negociando com a secretaria, pressionando.

Através da fala do professor, fica claro que as transformações ocorridas no Ayres de Moura daquele momento estavam também presentes em esferas maiores. A efervescência política, social e cultural perpassava a sociedade brasileira e, como já foi visto independentemente da extensão, profundidade e teor -, mudanças na política educacional do Estado estavam também acontecendo. Os professores do Ayres não eram os únicos descontentes com a situação dada.

Especificamente na escola, a questão legal parece não ter sido o problema central, já que os depoimentos apontam tanto para a habilidade dos participantes do movimento em aproveitar as brechas permitidas pela legislação, como também para sua capacidade de organização e reivindicação quando necessário ${ }^{53}$.

O fato é que, na virada da década de 1980, mudanças ocorriam de forma vertiginosa no país e no Ayres de Moura em particular. Entretanto, algumas considerações se fazem necessárias quanto à extensão das mudanças que ocorreram especificamente dentro dessa escola.

Ao referir-se às escolas democráticas, Singer (1997), ressalta que o termo é uma construção, um recorte,

\begin{abstract}
“[...] tendo por base duas características: a presença de assembléias escolares, nas quais todos os membros da comunidade têm o mesmo poder de voto e onde são tomadas todas as decisões relativas ao cotidiano, desde os pequenos problemas do dia-a-dia até questões relativas à própria estrutura escolar; e aulas opcionais, que mantém o respeito à liberdade de o aluno decidir se
\end{abstract}

\footnotetext{
${ }^{52}$ Referindo-se à divisão entre exatas humanas e biológicas e uma série de disciplinas, tais como PIP - Programa de Informação Profissional, Organização e Normas, Contabilidade Básica, Mercadologia, Desenho Técnico Básico, Noções Básicas de Agricultura e Zootecnia e Eletricidade.

${ }^{53}$ Não se considerou a investigação das alterações na legislação, uma vez que a preocupação desse estudo reside no fato de como os professores e alunos iam modificando a escola no âmbito o menos jurídico possível.
} 
deseja ou não assistir às aulas e acompanhar os cursos.” (SINGER, 1997, p. 15 - grifos da autora $)^{54}$

Por sua vez, Teixeira (2000) postula que escolas democráticas seriam espaços de exercício da autonomia cujas estruturas de funcionamento permitem a discussão e decisão inclusive quanto à elaboração de seus projetos pedagógicos. Em outras palavras, a interferência no currículo pela comunidade escolar é condição para a existência de uma escola democrática:

\begin{abstract}
"Outro aspecto contido na idéia de participação na tomada de decisões em escolas democráticas é o reconhecimento de que todos são portadores de algum conhecimento válido, que deverá ser levado em conta na elaboração do projeto pedagógico da escola. [...] Eleger valores que nortearão o processo educacional, construir um currículo, definir procedimentos, acompanhar o desenvolvimento das atividades de ensino e avaliar esse 'caminho' e seus resultados são experiências em que alunos, professores, pais, servidores da escola e a comunidade - num sentido bem amplo -, aprendem, ensinam, recordam passagens de suas vidas e podem passar momentos inéditos entre 0 que já tenham vivido.” (TEIXEIRA, 200, p. 36-38) ${ }^{55}$
\end{abstract}

Utilizando os critérios acima expostos, é possível refletir acerca dos limites da experiência do Ayres de Moura.

Após a apropriação da escola pelos alunos e professores, a partir de 1984, cabia ao próprio aluno decidir sobre a sua presença nas salas de aula para o acompanhamento dos cursos. Entretanto, a legislação sempre foi utilizada: o aluno tinha direito a 25\% de ausência sobre o total do número de aulas dadas ao longo do ano letivo. Caso excedesse esse montante, estaria automaticamente em recuperação por faltas e, ultrapassando os 50\%, retido.

Como já foi visto em maiores detalhes, a participação de todos nas diversas instâncias de decisão com as quais a escola contava sempre foi garantida, variando sempre através do tempo, mediante as necessidades postas em cada momento. Num exemplo prático, a presença de todos os alunos nos conselhos de classe, a cada bimestre, provou-se inviável, dado o tamanho da escola e a quantidade de alunos e professores. Desse modo, alternativas foram coletivamente buscadas, decidindo-se pelo sistema de representação. No

\footnotetext{
54 SINGER, Helena. República de crianças - Sobre experiências escolares de resistência. São Paulo: HUCITEC, 1997.

55 TEIXEIRA, Beatriz de Basto. Por uma escola democrática: colegiado, currículo e comunidade. 2000. Tese (Doutorado). FEUSP, Universidade de São Paulo, São Paulo, 2000.
} 
que diz respeito, entretanto, aos congressos, a participação de todos através do voto direto sempre foi garantida.

Quanto ao currículo, há que ser analisado em recortes muito precisos. Por exemplo, ao considerar o espaço físico como um dos inúmeros elementos que o constituem, é possível detectar transformações de grande peso, ao considerar alunos não só ocupando o prédio, como também decidindo sobre a forma dessa ocupação ${ }^{56}$.

Considerando, entretanto, uma outra dimensão do currículo - as disciplinas -, é possível perceber que a extensão das mudanças foi limitada. Isso devido a vários fatores. A comunidade "num sentido mais amplo" tal qual especificada por Teixeira (2000) nunca teve nenhum tipo de atuação dentro da escola.

Pelo fato do Ayres de Moura ser uma escola de segundo grau, a participação de pais nunca foi significativa, assim como também a dos funcionários, se comparada aos alunos e professores, uma vez que numericamente eram inexpressivos.

Não obstante a receptividade por parte de determinados professores, no sentido de levar em conta o conhecimento trazido pelo aluno na elaboração do currículo (disciplinas) a ser aplicado na escola, tal fato nunca ocorreu sob a forma de um projeto pedagógico formal, envolvendo a todos os professores. Algumas questões, como por exemplo, o item 1.2.n, das resoluções do I Congresso - “no início do ano letivo, o planejamento deverá ser feito por professores e alunos” -, acabaram por não ser viabilizados. Isso não significa, por outro lado, que a prática de determinados professores não levassem os interesses dos alunos em consideração.

C.E.R.: Tinha aquele projeto do 'E.', [professor de história] de cidadania e conservação do patrimônio público. Era uma coisa grande, que englobava biologia - a 'K.' [professora de biologia] explicava o que era e como viabilizar uma usina de compostagem, na escola. Eu e o 'Arl.' [professores de história] fizemos excursões a museus com os alunos, a 'D.' [professora de física] estava querendo montar na escola uma máquina ou coisa parecida para reciclar papel; foi colocado nas salas de aula três latas de lixo de cores diferentes para que depois pudesse ser selecionado. Latas inclusive, que os próprios alunos, muitos do noturno, traziam prá escola... Tinha o

\footnotetext{
${ }^{56}$ Diversos exemplos podem ser encontrados no item III das resoluções do I Congresso: "Medidas relacionadas à utilização e manutenção do prédio escolar" e também itens 4: "Melhoria das condições materiais da escola" e 5: “Outras propostas” das propostas aprovadas do V Congresso (Anexos III e VIII, respectivamente).
} 
'B.' [professor de educação artística] com as aulas de grafitagem. Especificamente sobre esse projeto, por exemplo, muita coisa foi feita, mas nem tudo saiu do papel. Eu comecei a dar aulas no Ayres em 1989 e me lembro que a gente tinha liberdade prá desenvolver qualquer coisa que desse vontade. Mas a gente se juntava mais por afinidade: um professor conversava com outro, a gente convidava outros de outras áreas, chamava os alunos e fazia. Mas nada que tomasse a escola inteira, de uma vez só, todo mundo. Por um lado, talvez fosse falho, mas por outro, só fazia quem estava a fim. Às vezes, quando todo mundo tem que participar, muitos fazem por obrigação, $e$ aí não sai direito. Era comum ver professores participando de mais de um projeto ao mesmo tempo.

Mediante ao que até aqui foi exposto, a análise da prática do Ayres de Moura talvez não permita classificar a escola como democrática considerando os critérios propostos por Singer (1997) e Teixeira (2000), ou seja, participação em assembléias, desobrigação da participação nas aulas e construção do currículo pela comunidade escolar.

Entretanto, é necessário destacar que, dentro da especificidade da escola em questão, o modelo acima citado não era meta a ser alcançada, pelo menos não na totalidade dos detalhes. Isso fica claro, quando se percebe que ao instaurar o processo de auto-gestão, o projeto da escola foi sendo construído e reconstruído ao longo da sua própria aplicação, como se não houvesse meta a ser alcançada. Ao mesmo tempo, esse projeto parecia inexistente, se pensado em termos de formalidade, de temas geradores, interdisciplinares ou transversais, englobando a todos os professores e as disciplinas da escola.

Tomando outros critérios como instrumentos de análise, era fato que, por exemplo, a escola não tinha o vestibular com preocupação central - com a exceção de um número muito reduzido de professores. Inclusive, questões de múltipla escolha em avaliações haviam sido banidas da escola, independente da disciplina ministrada. O conjunto dos professores de história da escola, por exemplo, também havia desde o início do processo, banido os “questionários” da prática escolar.

Assim, se pudermos imaginar um projeto pedagógico “oculto” na escola, ou seja, não constante dos documentos oficiais, da burocracia da escola, constataremos que os valores democráticos da participação nos processos de deliberação, da tolerância, da argumentação e reivindicação eram itens que constituíam o conjunto do conhecimento a ser 
transmitido/construído dentro da escola, perpassando as diversas disciplinas, salas de aula e o espaço escolar mais amplo.

Tais valores, obviamente, variavam em intensidade de acordo com a visão de mundo que cada integrante da comunidade escolar trazia, e transformava-se, no conflito permanente existente no espaço do Ayres de Moura. 


\title{
Capítulo IV - O esgotamento
}

\begin{abstract}
"Nós não esperamos nada de cima. Além de a gente gostar de dar aula, existia a militância política. Antigamente a gente discutia muito que as condições históricas faziam as... [pausa] mas eu acho que são as pessoas, nas condições históricas, que fazem. Eu fico pensando: tem pessoas tão ótimas, mas às vezes elas não estão no lugar certo $[\ldots] ”$ (ex-professor)
\end{abstract}

Independentemente dos avanços significativos que a comunidade do Ayres de Moura conseguiu imprimir no cotidiano da escola por aproximadamente dez anos, alguns deles já analisados nos capítulos anteriores, o presente estudo ressalta que problemas sempre existiram na escola, tanto quanto em quaisquer outras da rede pública.

No início da década de 1990, a escola contava com aproximadamente 100 professores e por volta de 1.000 alunos, distribuídos ao longo dos três períodos. Eram oferecidos os cursos de segundo grau regular, com a duração de três anos, nos períodos da manhã e à noite, magistério matutino e magistério noturno e, além disso, nas dependências da escola também passou a funcionar, a partir de 1989, o projeto CEFAM $^{57}$, em período integral (manhã e tarde).

C.E.R.: [referindo-se ao número de turmas na escola] Eu me lembro que, em 91 ou 92, não sei ao certo, juntando tudo, só de primeiros anos, tinha de $1^{\circ} \mathrm{A}$, no período da manhã, até $1^{\circ} S$ ou $T$, no noturno. Havia muitas classes de segundo ano também. Os terceiros anos eram em menor número, mas mesmo assim eu me lembro de dar aulas em $3^{\circ} \mathrm{F}$, $3^{\circ}$ G. Isso sem contar o CEFAM.

\footnotetext{
${ }^{57}$ Os Centros Específicos de Formação e Aperfeiçoamento do Magistério - CEFAM foram criados pelo Decreto Governamental no 28.089 de 13 de Janeiro de 1988, no âmbito da Rede Estadual de Ensino. Os objetivos do projeto e demais informações acerca de seu funcionamento constam da resolução SE $n^{\circ}$. 14 de 28 de Janeiro de 1988, publicada no DOE em 22 de março de 1988. Os dados foram obtidos no site da CEI - Coordenadoria do Ensino do Interior, Secretaria de Educação do Governo do Estado de São Paulo $<$ http://cei.edunet.sp.gov.br/subpages/pedagogicos/educefam.htm>. Acessado em 02 nov. 2006.
} 
Segundo informação verbal da ex-diretora eleita pelos alunos e professores, havia entre quatro e cinco funcionários responsáveis pela limpeza. Era comum a falta de verbas, que obrigava a escola a levantar recursos por seus próprios meios, inclusive para contratação de pessoal $^{58}$, uma vez que o quadro de funcionários administrativos era insuficiente para que o trabalho da secretaria fosse realizado adequadamente. A falta de professores e a crescente rotatividade de profissionais, sentida mais e mais ao longo da década de 1990, também era outro fator que dificultava o dia a dia da escola.

A despeito do problema com relação à segurança, também sendo gradualmente sentido com o passar do tempo, os portões da escola permaneciam abertos. Isso era um ponto que o coletivo da escola defendia com veemência, por ser a materialização do gerenciamento do espaço conquistado desde o I Congresso, em 1983. No início dos anos 1990, solicitando na delegacia local, a escola contava com o auxílio de um soldado da polícia militar que circulava pelos prédios, em determinados horários.

Em termos estritamente pedagógicos, mesmo após a implantação do novo sistema na escola, em 1984, havia professores - alguns inclusive efetivos - descomprometidos com o projeto da escola e com a qualidade do serviço oferecido aos alunos, embora não fosse essa a característica marcante do corpo docente como um todo, já que, por conta da forma como o Ayres de Moura funcionava, os diferentes segmentos da escola - professores, alunos, funcionários e direção ficavam permanentemente expostos ao coletivo.

E.: Houve professores que até foram tirados, [saíram da escola de alguma maneira, muitas vezes sob pressão] mas era difícil, porque a legislação acaba protegendo, então muitas vezes o cara tinha que ser pressionado, porque tem muito picareta que dá aula no Estado. Havia conflitos, as coisas não aconteciam assim de uma maneira harmônica e progressiva. Era luta diária, onde tinha que se matar um leão por dia. Mas havia um grupo bom de professores. Eu acho que muito se deu por essas pessoas que estavam dando a direção da coisa, naquele momento, aproveitando as condições históricas. Havia uma complementação das pessoas.

O trecho acima selecionado ilustra uma das preocupações do presente estudo, que consiste em procurar entender o fato de que, se o contexto histórico-social no qual as

\footnotetext{
${ }^{58}$ Por meio de festas juninas, por exemplo.
} 
transformações acontecidas no Ayres de Moura era comum às demais escolas da rede pública, que fatores contribuíram para sua especificidade? O que fez com que as condições históricas, dentro da escola e apesar de todas as adversidades, fossem aproveitadas daquela forma?

À medida que os depoimentos eram obtidos, na busca pelo entendimento dessa questão, os entrevistados, na maior parte das vezes, ao abordar as origens, discorriam, ao mesmo tempo, sobre o esgotamento da experiência ocorrida no Ayres de Moura. Tanto num caso quanto em outro, o conjunto dos indivíduos - o coletivo - era sempre mencionado pelos depoentes como um dos principais fatores responsáveis.

E.: $\quad$ Foi justamente por quê? Eu acho que as coisas são feitas por pessoas. Depende muito da qualidade dessas pessoas. [...] Sabe aquela coisa de formação, de caráter, de empenho, de comprometimento? Aquela pessoa que é o cidadão? Ela pode estar em qualquer emprego, pode ser o faxineiro da escola, o professor, o aluno, mas ela faz as coisas bem feitas. E eu acho que houve pessoas [no início] que se empenharam. Depois [ao longo dos anos] também iam entrando pessoas comprometidas, mas se ganhava mal, havia mais possibilidades fora [da escola pública] então, muitos jovens [professores] bons - eu lembro do 'J.', do 'Arl.', da 'S.' - de uma série de pessoas boas que foram saindo. Eles tinham consistência, inteligência, boa formação, tudo, mas a escola já não oferecia mais... não havia mais perspectiva enquanto carreira, eles viam os professores mais antigos - eu mesmo - um professor há tanto tempo e ganhando pouco, levando uma vida... sabe, você não pode exigir que a pessoa queira isso. E aí vão ficando na escola pessoas muito mal preparadas, mal formadas, que não entendiam aquilo tudo, nem o próprio comprometimento da gente. Tinha gente que pensava que nós éramos loucos, outros tinham ciúmes, inveja. Também, eu acho que o fato de o PT ganhar eleições [referindo-se à gestão de Luiza Erundina na prefeitura de São Paulo] levou muita gente da escola para a administração municipal. Gente boa. Outras pessoas buscaram outras opções de emprego...

C.: $\quad$ Tem escola que aproveita o momento e tem escola que não. Voltando um pouco: na época [segundo a professora, em meados da década de 1980] eu me engajei num projeto da Sabesp que as escolas podiam se inscrever e engajei a escola toda. Era 
um projeto de interdisciplinaridade, tendo o meio ambiente como tema gerador, como eixo, que deveria passar por todas as matérias. Eu fui atrás e inscrevi o Ayres de Moura. Mas eu estou falando isso prá dizer o seguinte: havia outras escolas, quer dizer, não foi só o Ayres na época. Eu acompanhei o trabalho de outros professores em outras escolas, e tinham trabalhos maravilhosos também. Eu me lembro que tinham umas oito escolas que se inscreveram nesse programa. No período inicial do CEFAM, [1989] quando eu fui coordenadora, foi a mesma coisa: o Ayres teve uma experiência de CEFAM positiva, e eu acompanhei outras escolas que também tiveram. Porque oportunidades existiam, dependia das pessoas. É uma conjunção de fatores, entre eles você junta um grupo bom, um grupo com formação, um grupo que está a fim de ensinar e, sobretudo, idealista. Que queria fazer alguma coisa, queria mudar alguma coisa através da educação, você tem um grupo de pessoas que estão juntas, que tem um interesse comum, que gostam do que fazem, $e$ culmina com esse movimento.

A.C.: Acho que foi a ideologia. Então eu acho que ninguém estava lá - não que quisessem trabalhar de graça - mas não era apenas pelo valor da hora-aula. Muitos professores tinham outras atividades e também potencial para fazer outras coisas. Todos vindo de boas faculdades. É difícil encontrar uma escola com esse nível, que as pessoas tenham um ideal de educação e de transformação. Eu acho que a preocupação no Ayres era a transformação. Eu trabalhei em outras escolas ${ }^{59}$, e lá as coisas simplesmente passavam. Não existia aquela vontade de fazer alguma coisa diferente. Às vezes eu queria por fogo, vamos fazer isso? Vamos fazer aquilo? E o pessoal falava: 'ah, não dá certo...' No Ayres era diferente, todo mundo topava. Agora, eu trabalhei muito lá, viu? Ninguém tem noção do que eu trabalhei naquela escola. Eu tinha que mentir pro meu marido, eu falava que ia prá um churrasco na casa de um professor, que era aniversário de fulano e eu ia pro Ayres trabalhar: fazer folha de pagamento, responder processos, contagem de tempo para aposentadoria de algum professor... (risos) Mas eu acho que valeu a pena, sabe? Hoje eu sinto saudade... Agora, eu acho que com o passar do tempo, o Ayres começou a decair mesmo. Mesmo por conta da formação. Você não achava professor prá dar aula, muita aula vaga. Foi aí que começou a decadência. Tem um pessoal novo que vai entrando, que não consegue

\footnotetext{
${ }^{59}$ Em uma delas, inclusive, ocupando o cargo de direção.
} 
nada melhor, [em termos opções profissionais] então vai prá escola prá 'dar umas aulinhas'. Isso é geral, não só no Ayres. Mas eu continuo afirmando: comparando com outras escolas na mesma época, ainda assim a gente conseguia sobressair.

A seleção das falas acima, nos permite refletir acerca de alguns pontos de grande importância. Primeiramente, a experiência alternativa do Ayres de Moura não foi única, considerando o conjunto das escolas da rede estadual de São Paulo nos anos de 1980, ainda que tenha sido singular sob inúmeros aspectos, alguns deles aqui analisados. Outras escolas também inovaram e imprimiram suas marcas. Tanto que uma das preocupações desse estudo é registrar a experiência dessa escola para que não se perca como tantas outras.

Em segundo lugar, fica explícita a idéia de que comprometimento que perpassa os depoimentos é constituído de muito mais do que valores morais. Os professores comprometidos, no Ayres de Moura tinham assumidamente claro - e este é o grande diferencial -, que a boa formação do profissional era não só intelectual mas também política, que educar pressupunha também militância, não no sentido político-partidário do termo, mas enquanto possibilidade de transformação social.

Além disso, a especificidade do Ayres de Moura pode também ser explicada porque os diferentes segmentos da escola - professores, alunos e funcionários -, conseguiram construir um coletivo, uma comunidade.

No sentido de melhor desenvolver tal argumento, faz-se necessário tecer algumas considerações a respeito do conceito de comunidade.

“A comunidade pode ser um grupo de indivíduos que têm algo em comum como em 'comunidade hispânica' -, sem necessariamente viver em um dado lugar. Pode ser um senso de ligação com outras pessoas, de integração e de identificação, como em 'espírito de comunidade' ou 'senso de comunidade'. E também um grupo de pessoas que realizam tipos de trabalhos relacionados entre si, como em 'a comunidade da saúde' ou 'a comunidade acadêmica'. E talvez em seu sentido mais comum e concreto, pode ser um conjunto de pessoas que compartilham de um território geográfico e de algum grau de interdependência que proporcionam a razão para viverem na mesma área. [...] De modo geral, contudo, comunidades geograficamente localizadas implicam viver, trabalhar e realizar as atividades básicas da vida dentro de um território definido pelos seus residentes como tendo identidade 
geográfica, refletida mais vivamente pela atribuição de nomes a regiões e ao traçado de fronteiras.” (JOHNSON, 1997, p. 45)

\begin{abstract}
"Depois de examinar detidamente 94 noções de comunidade, G. A. Hillery chegou à conclusão que de que 'exceto quanto à concordância pacífica de que as pessoas vivem em comunidade, nenhum consenso existe entre os cientistas sociais quanto a sua natureza' (Definitions of community: areas of agreement. In: Rural sociology. 1955. v. 20, p. 119). Embora o termo tenha sido empregado variadamente como sinônimo de sociedade, organização social ou sistema social, muitos autores concordam que a comunidade tem um locus territorial específico, geralmente limitado. E essa parece ser a maneira pela qual o termo é mais comumente usado pelos pesquisadores. [...] R. A. Nisbet (The quest for community. New York, Oxford Univ. Press, 1953) parece usar comunidade como sinônimo de sociedade ou sistema social, mas acrescenta ao conceito a restrição de que a integração ou 'um sentido de participação' caracteriza a comunidade." (SJOBERG, 1986, p. 229) ${ }^{61}$
\end{abstract}

Em estudo feito sobre escolas democráticas e a possibilidade da disseminação de um modo de vida mais democrático, Teixeira (2000) coloca em detalhes o debate teórico travado na academia, ilustrando, dessa forma, a complexidade subjacente ao conceito de comunidade.

Especificamente referindo-se a comunidade e escola, a autora questiona:

\begin{abstract}
"Como falar de comunidade local em relação à escola, tendo como pressuposto o que alguns sociólogos convencionaram chamar por esse nome? Uma escola localizada no centro da cidade de Belo Horizonte, por exemplo, recebe alunos de 230 bairros diferentes em sua clientela. Esses alunos, muitas vezes, moram em um bairro, trabalham em outro e estudam no centro - e passam o dia circulando pela cidade. Correto, mas essa não é a realidade de todas as escolas. Entretanto, mesmo aquelas que atendem alunos residentes do próprio bairro onde está localizada a escola, essa população satisfaz muitas de suas necessidades em outros bairros da cidade. A idéia de que ali poderia existir uma comunidade que 'resolve' a vida toda no bairro é muito pouco provável nos dias atuais. Ou ainda, resta saber se as pessoas se identificam como moradoras do determinado bairro, se tem algum sentimento de pertencimento em relação à sua população. Porque um traço comum a todas as definições do conceito de comunidade é a existência de um sentimento de pertencimento, uma identidade entre os participantes dessa relação - que pode estar fundada em sentimentos ou em escolhas racionais, mas deve sempre existir e é fator de coesão do grupo." (TEIXEIRA, 2000, p. 287)
\end{abstract}

\footnotetext{
${ }^{60}$ COMUNIDADE. In: JOHNSON, Allan G. Dicionário de sociologia: guia prático da linguagem sociológica. Rio de Janeiro: Jorge Zahar, 1997.

${ }^{61}$ COMUNIDADE. SJOBERG, Gideon. In: SILVA, Benedicto (Coord.). Dicionário de ciências sociais. Rio de Janeiro: Fundação Getúlio Vargas, 1986.
} 
Dessa forma, frente à profunda complexidade do tema e, para atender as necessidades específicas desse estudo, ao afirmar que os participantes da experiência do Ayres de Moura foram capazes de construir uma comunidade, sua definição fica assim, limitada e entendida como sendo o conjunto dos indivíduos que ocuparam a escola - não apenas fisicamente, porque lá estudaram ou trabalharam ${ }^{62}$, mas no sentido de a ela terem pertencido e sido, ao mesmo tempo, uma espécie de co-proprietários, sendo exatamente esse o principal fator de coesão do grupo: a participação nas relações de poder lá existentes de forma ativa, direta e deliberativa.

Esse sentimento de pertencimento à comunidade, o fato da existência de laços estreitos entre o indivíduo e a escola, ajuda a entender melhor - ainda que não justifique de forma absoluta -, casos como o de dois alunos que decidiram ser reprovados por conta própria $^{63}$, para permanecerem na escola, ou ainda como alguns professores que trabalhavam aos domingos, sem remuneração extra.

De qualquer modo, é possível afirmar que, embora o contexto histórico da virada dos anos 1980 fosse comum a todas às escolas, o grupo presente no Ayres de Moura naquele momento soube aproveitar e transformar a escola, tanto quanto fosse possível, tendo em vista os limites e obstáculos que o projeto enfrentou.

Entretanto, a tentativa de compreender como o Ayres de Moura vai perdendo suas conquistas pouco a pouco, ao longo da década de 1990, implica também levar em consideração outros elementos, alguns já anunciados entre as falas dos professores selecionadas neste capítulo, como por exemplo, a posse de Luíza Erundina na prefeitura da cidade de São Paulo, que levou vários professores e alguns alunos a deixarem a escola, assumindo cargos naquela gestão.

Um dado presente em todas as entrevistas, sem exceção, foi a saída da diretora eleita, por motivo de aposentadoria.

E.: $\quad$ É a saída de uma pessoa de muita competência. Porque a escola funcionava com a direção da 'A.C'. e da 'M.', elas faziam funções diferentes dentro da escola. A 'M.' sozinha, não conseguia, lógico. Era muita coisa. E não tinha funcionário, aquela coisa do Estado estar enxugando tudo. Não tinha verba. Não tinha verba prá por uma

\footnotetext{
${ }^{62}$ Mesmo porque, a grande maioria dos alunos era proveniente de bairros circunvizinhos e não exclusivamente moradores da Vila Jaguará. No caso dos professores a situação era a mesma.

${ }^{63}$ Para mais detalhes, ver nota de rodapé $n^{\circ} 43$ do Capítulo III.
} 
pessoa no portão, entende? A situação já estava ficando muito difícil em termos de segurança. A escola estava muito abandonada, na verdade.

A estrutura de funcionamento, que a comunidade do Ayres de Moura acabou por construir, demandava muito do professor e, mediante as inúmeras mudanças ocorridas dentro e fora da escola, torna-se cada vez mais difícil a sua manutenção. A grande rotatividade de professores, muito acentuada ao longo da década de 1990, dificulta aos novos ingressantes a absorção da proposta da escola. Além disso, os professores mais antigos vão deixando a escola, muitos também por motivo de aposentadoria.

Quanto à entrada de professores mais novos, foi levantada a questão do problema da formação, não só intelectual como também política. Mesmo professores novos considerados “bons” pelo coletivo da escola, geralmente tendiam a permanecer lá por pouco tempo. Na opinião de um ex-professor:

C.E.R.: O Estado na verdade acabou sendo transformado numa espécie de estágio remunerado prá quem está em fase de formação ou é recém-formado. A gente passa um tempo por lá e sai preparado para dar aulas em quaisquer circunstâncias, de tantos problemas que a gente enfrenta. Pega experiência e vai prá outro lugar, ganhar melhor.

C.: $\quad$ Eu não sei, eu acho que o grupo se enfraquece. Vão saindo pessoas importantes no movimento, e o grupo que o sustentava vai se enfraquecendo, falta liderança, é a mesma questão política que a gente vê hoje. Quem vai ficando vai tendo dificuldade de continuar, as salas ambiente vão se esvaziando, porque uma proposta pedagógica avançada, mais arrojada, dá trabalho. Ela demanda trabalho. Você tem que ter planejamento, tem que ter avaliação, tem que retomar o tempo inteiro, você planeja, executa, avalia, volta, refaz a proposta, discute de novo: é um movimento espiral, que vai, vai, vai e as pessoas às vezes não querem fazer isso: é 'vai pra escola, dá a aulinha, vem da escola'... mesmo porque, o professor muitas vezes dá aula em várias escolas, você vai perdendo a energia. 
Além de mudanças não só nas políticas educacionais, o panorama político nacional também foi mencionado nos depoimentos:

E.: $\quad$ Eu acho que é uma época de pós-Collor, sabe? Aí você tem governadores, figuras como o Quércia, o Fleury. Então, um governo ruim atrás do outro. Depois, quando veio o Covas, que era um cara que a gente esperava uma melhoria, o que aconteceu foi fechamento de escola, atitudes totalmente autoritárias, politicamente. Quer dizer, nunca houve plano prá educação, nunca houve nada sério. Cada um fazia o seu grande plano mirabolante de educação, aquela coisa, você faz CEFAM, você faz Escola-Padrão, quer dizer, custava caro e eram todas, na verdade, atitudes demagógicas.

K.: $\quad$ Eu acho que a própria visão que o governo tem de educação acabou com as escolas. Em vários lugares foi extinto o segundo grau. O Gepam ficou inchado porque eu acho que na região ficou só ele mesmo. E isso é da cabeça do governo, que trata a educação como se fosse sei lá o que.

E.: $\quad$ Houve uma decisão que foi do governo Covas de unificar as escolas, de mudar os períodos. A secretaria de educação fez o que? Agrupou os períodos das escolas a uma idade, prá não misturar aluno grande com aluno pequeno. E veio o pessoal do Altenfelder $^{64}$ : o segundo grau de lá foi anexado ao Gepam, teve que acomodar. Assim, sem mais, nem menos! Inclusive, diminuiu vagas, o Gepam deixou de pegar mais ou menos cento e vinte alunos. Juntou todo aquele pessoal, muitas classes. E professores também. Então nós discutimos para fazer o melhor possível, a gente queria misturar todo mundo, era uma pena inclusive porque os alunos do Altenfelder não tinham a base que o pessoal do Gepam tinha e não tinham a história de cidadania. Deu muito problema: você anexa uma outra escola no Ayres, que já tinha o CEFAM funcionando lá. Aí você pega professores dessa outra escola que se aliam com pessoas do próprio Ayres/CEFAM que não se sentiam fazendo parte da coisa toda, e vão boicotar tudo: você começa a ficar minoria e mal dá prá você organizar sala ambiente, sabe? Aí veio

\footnotetext{
${ }^{64}$ Referindo-se a outra escola bem próxima, que comportava cursos de primeiro e segundo graus e que, com a reforma mencionada, fica sendo apenas de primeiro grau (atual Ensino Fundamental II), sendo o restante dos alunos transferidos para o Ayres de Moura.
} 
uma diretora que não tinha o menor comprometimento, boicotando, e não tinha oposição muito grande. Eu pensei: 'estou ficando muito sozinho no Gepam'. Os companheiros como quem eu podia contar: tinha a 'J.' e a 'N.', o restante tinha se aposentado. Eu falei: 'eu preciso sair daqui'. Eu quase peguei uma escola no Parque Continental que é uma escola boa. O pessoal fala bem dela, mas eu acho que a secretaria de educação está sempre perseguindo no sentido de destroçar tudo. Eles também fizeram um sistema de destruição de aula, prá acabar com os grupos dentro das escolas. Prá desorganizar os professores. Em termos de atribuição de aula, os professores escolhem na delegacia de ensino. Então, há um rodízio muito grande entre os professores que não são efetivos, então não forma um grupo.

Como é possível perceber, os depoimentos acima selecionados apontam uma gama de aspectos que contribuem para o enfraquecimento do movimento ocorrido na escola, mostrando também a alta complexidade da dinâmica que lentamente leva aquela experiência ao seu esgotamento. Ainda que o desligamento da diretora e a saída paulatina de elementos importantes na condução e continuidade do projeto causassem um grande impacto na escola, o fato é que o contexto histórico mais amplo - o mesmo que permitiu que o grupo presente na escola fizesse tudo aquilo que fizeram no início dos anos 1980 - minava o funcionamento da escola dentro dos moldes em que vinha operando há aproximadamente dez anos.

O ingresso de professores qualificados e comprometidos, que entendessem a proposta - conforme já mencionado pelos professores - não impediu o esgotamento do projeto. Vários entre esses professores, inclusive, mencionaram que se desligavam da escola contra a vontade, mas as condições de trabalho dos docentes, as questões de ordem salarial e a falta de perspectivas na carreira não lhes deixavam opção.

Quanto ao ingresso de professores mal preparados, intelectual e politicamente, que ao longo dos anos 1990, passam a compor o grupo dos “novos” dentro da escola -, também entravam em choque com os “velhos”, intensificando ainda mais as dificuldades que a escola enfrentava.

Desse modo, a E.E.S.G. Prof. Ayres de Moura, que até o final da década de 1980 era de todos, da comunidade - pública enfim -, através de um longo processo e não sem resistências, começa a transformar-se numa escola “do Estado”, de ninguém. 


\title{
Considerações finais
}

\begin{abstract}
"A experiência do Gepam foi uma formação de lideranças que não era esperado, mas acabou sendo, porque saiu um pessoal muito bem formado."
\end{abstract}

(ex-professor)

Pensar em tudo o que foi feito no Ayres de Moura, em como as pessoas que lá estavam depositaram suas esperanças, convicções e esforços num projeto, é um exercício bastante apaixonante. Encontrar os amigos - pessoas que estudaram comigo, que foram meus professores, que lecionaram comigo e outros ainda, que foram meus alunos -, a cada eleição, já que muitos de nós votamos na escola ${ }^{65}$, é também fonte de muita nostalgia.

Em meio a esses sentimentos, sempre suscitados ao pensar na escola e em tudo o que lá foi feito - sentimentos que inclusive motivaram esse estudo -, quatro questões são aqui levantadas.

A primeira delas surgiu de observações feitas, em diversas ocasiões, de que muitos dos participantes do movimento - e nesse caso, mais professores que alunos - acabavam suspendendo os limites entre as esferas públicas e privadas, criando certa confusão entre um e outro, atestadas por expressões, como por exemplo, a "minha” sala ambiente. Isso, entretanto, parecia mais advir do envolvimento emocional daqueles participantes do que de equívocos teórico-conceituais.

Além disso, embora importante, a questão afetiva por si só não explica o compromisso existente entre o coletivo e a escola. Essa questão, tão enfatizada ao longo do presente estudo, assenta-se no fato dos alunos e professores daquele período realmente se sentirem donos daquele espaço, já que efetivamente o ocuparam, decidindo sobre seu funcionamento. Em outras palavras, a escola estatal, que na grande maioria das vezes é tratada como privada, pois tem um “dono", um "chefe" 66 , foi transformada, por um determinado período de tempo, em escola pública e aqueles que a vivenciaram estavam conscientes disso.

\footnotetext{
${ }^{65}$ Houve casos, inclusive, das urnas estarem montadas na minha ex-sala ambiente!

${ }^{66}$ Assim como foi a “I.” no Ayres de Moura até a virada da década de 1980.
} 
A segunda questão refere-se à relação existente - e indissociável - entre as esferas política e pedagógica, ressaltando, dessa forma, a impropriedade da redução de assuntos pedagógicos a questões meramente técnicas.

As práticas de associação, reivindicação e tomada de decisões coletivas; o respeito por essas decisões; e a consciência de sua temporalidade, uma vez que são passíveis de modificações, foram acrescentadas na lista dos conteúdos a serem ensinados no Ayres de Moura.

Além disso, citando alguns exemplos práticos, temas como ecologia, cidadania e conservação do patrimônio público - tão caros nos discursos do momento atual - já eram trabalhados na escola em meados dos anos 1980 e de maneiras bastante diversificadas e alternativas. Se isso pôde acontecer na escola, naquele momento, suas razões estão assentadas nas transformações de cunho político, uma vez que, graças ao modo pelo qual aquele espaço foi construído e gerido pelo coletivo, arbitrariedades individuais não conseguiam nem apoiar e nem impedir as atividades dentro da escola, como acontecia até o final da década de 1970.

Mais ainda, a socialização das experiências que lá ocorriam aconteciam de tal modo que os participantes daquele coletivo estavam, todos, em constante processo de aprendizagem, já que eram direta ou indiretamente afetados pelo que acontecia no dia a dia da escola.

Obviamente, as transformações ocorridas no Ayres de Moura tiveram limites. Ainda especificamente no campo pedagógico, muita coisa pensada não foi viabilizada (participação dos alunos no planejamento dos cursos, no início de cada ano letivo) e, salvo casos isolados, pouco se modificou em atitudes referentes à avaliação, por exemplo.

Um terceiro ponto, de grande importância, diz respeito ao coletivo, ou, conforme já especificado no capítulo IV, à comunidade - entendida como um grupo coeso, assim mantido por conta de uma identificação, de um sentimento de pertencimento, advindo da experiência concreta da ação política sobre os destinos do espaço por eles apropriado. Diz também respeito às condições internas e externas que propiciam existência desse grupo.

Já foi visto em detalhes o processo pelo qual, graças à ação, entendida dentro do modelo proposto por Arendt $(2004)^{67}$, um movimento crescente - garantido, não sem

\footnotetext{
${ }^{67} \mathrm{O}$ conceito foi desenvolvido em detalhes na página 47 do presente estudo.
} 
dificuldades e obstáculos, por toda a conjuntura da virada da década de 1970 para 1980 e iniciado a partir de um pequeno núcleo -, expande-se, culminando na apropriação da escola.

Entretanto, pretende-se aqui ressaltar que, após essa apropriação, a direção do movimento, ao invés de concentrar o controle da escola em si mesmo, pelo contrário, abriu espaço para que todo o coletivo participasse da condução do Ayres de Moura, num processo cuja característica principal, durante determinado tempo, consistiu na avaliação, discussão e implementação de ações referentes a questões das mais diversas ordens que afetavam a vida de todos e cuja participação era efetivamente a todos garantida, como pode ser observado nas resoluções dos congressos constantes dos anexos desse estudo.

Todo esse movimento fez com que fosse criada, dentro da escola, uma estrutura de funcionamento bastante complexa, de constante re-elaboração, que demandava muito tempo, trabalho e compromisso. Enquanto as condições internas e externas assim permitiram, o coletivo da escola pôde existir e se reproduzir, garantindo assim a continuidade do projeto, que se esgotou, quando o conjunto dos indivíduos, por inúmeras razões, algumas delas desenvolvidas em detalhe no capítulo IV, deixaram de ser uma comunidade, um coletivo.

Entretanto, cabe observar que, por falta de palavra mais adequada, o "esgotamento" da experiência do Ayres de Moura não é um fenômeno natural: o crescente abandono da escola pública, a inviabilização do magistério enquanto carreira profissional, a desqualificação crescente dos professores, o recrudescimento dos avanços conquistados a partir da abertura política em meados da década de 1980 são alguns dos aspectos que ilustram as ofensivas, a perda, de certa forma, de mudanças que por determinado momento acenaram no horizonte do contexto político-social maior.

A quarta e última questão consistia em saber, por parte dos depoentes, se seria possível pensar numa experiência diferenciada, de alguma forma, da média das escolas públicas nos dias de hoje, mesmo sabendo que o movimento ocorrido no Ayres de Moura jamais poderia ser re-editado, dado o diferente contexto histórico-social, sem contar as especificidades de cada caso:

A.C.: $\quad$ Eu acho que é difícil, pela própria formação pedagógica dos professores de hoje. Dificilmente você encontra numa escola, um corpo docente pensando numa formação do aluno, no amanhã. Eles vão lá prá dar aula, ganhar um salário, miserável, e pronto. E eu acho que não existe mais aquela ideologia. 
K.: $\quad$ Olha, eu não sei... infelizmente, está difícil. Pelo próprio ambiente que o professor encontra na escola. Eu confio muito nos professores, eu acho que vai mudar. Mas vai levar tempo. Infelizmente é assim, eu fico muito triste em ver a escola chegar nesse ponto. A gente fica deprimida. Eu não gosto nem de pensar.

C.: $\quad$ É possível. Outro dia ouvi o Dimenstein ${ }^{68}$ falando no rádio, eu lembrei de 20 anos atrás: 'porque tal escola funciona à base de assembléias.' A gente sabe que se a comunidade assumir uma escola... a escola é prá quem? Prá comunidade. Se a comunidade está ciente que a escola é dela, de que ela é pública, ninguém está fazendo nenhum favor, é de todo mundo e todo mundo cuida. O que a gente fazia na verdade, era justamente esse movimento: a escola é da comunidade. Ela tem que ter um fim na comunidade. Eu acho que dá prá fazer sim. Se você tiver um grupo, se você tiver... eu não estou tanto na escola pública hoje, mas eu sei que tem escolas melhores e escolas piores. Eu acho que tem problemas, mas tem formas da comunidade resolver e das pessoas tentarem discutir. Senão o que acontece? Todo mundo se enterra... eu não acredito em modelos, não dá prá dizer existe um modelo “ $x$ ” ou “ $y$ ”. Acho que existe um modelo prá cada comunidade e ela é quem vai discutir esse modelo, que foi o que a gente fez no Ayres. Se as leis permitem que você discuta e que você ache as formas alternativas...

E.: $\quad$ Na verdade existe uma esperança, que essa experiência alcance outras pessoas. Já está na academia, tem o trabalho da Néri, o da Ediógenes ${ }^{69}$ e agora o seu. As pessoas que formam professores vão entrar em contato, mesmo que diluído. Na verdade a gente espera que um dia volte, até na forma de políticas públicas, num bom governo, digamos, se a gente pudesse ter um bom secretário de educação e tal, capaz de interferir... porque um dia vai ter que interferir na escola no Brasil, nós estamos chegando ao descalabro. Você tem muita gente que estudou no Gepam... será que o Gepam não deixou semente?

\footnotetext{
${ }^{68}$ Jornalista brasileiro, colunista da Folha de S.Paulo, Revista Veja e CBN (90,5 FM e 780 AM). Dados obtidos no site <http://pt.wikipedia.org/wiki/Gilberto_Dimenstein>. Acessado em 13 nov. 2006.

${ }^{69}$ Referindo-se aos dois trabalhos anteriormente publicados sobre a escola, citados na Introdução (nota de rodapé número 2 - página 3) e constantes das referências bibliográficas.
} 
Pessoalmente, acredito que o Ayres de Moura deixou semente. Minha prática docente tem essa experiência como raízes e, através de uma ex-aluna da escola, formada em 1994 e atualmente matriculada no programa de pós-graduação da Faculdade de Educação da USP, tenho notícias de outros ex-alunos bastante atuantes, ligados de alguma forma a atividades educacionais. Mesmo a presente dissertação de mestrado é também um desdobramento daquela experiência, que pretendeu, entre tantas outras coisas, divulgá-la, torná-la pública:

“[...] pois, se é verdade que todo pensamento se inicia com a lembrança, não é menos correto que nenhuma memória perdura e permanece intacta, a menos que seja condensada e inserida num conjunto de noções conceituais, dentro do qual ela possa afirmar-se cada vez mais. As experiências e mesmo as narrativas que brotam de tudo aquilo que os homens fazem e atravessam, dos acontecimentos e ocorrências, se dissipam na inanidade inerente à palavra e aos feitos vivos, a menos que sejam discutidos e comentados vezes sem conta. O que salva as ações dos homens de sua inerente inutilidade não é outra coisa senão essa discussão incessante que se trava em torno delas, a qual, por sua vez, permanece inútil, a não ser que dê origem a certas concepções e a determinados marcos dominantes que favoreçam a futura evocação ou simplesmente lhe sirvam de referência.” (ARENT, 1988, p. 176)

É como se tentasse dizer: “vejam, foi possível!”. Houve inúmeros problemas, falhas, conquistas e avanços. Mas, por aproximadamente dez anos, tempo que durou a experiência do Ayres de Moura, salvo os limites que circunscreveram aquele movimento, seus participantes conseguiram não ser governados daquele modo, em nome daqueles princípios, por meio daqueles procedimentos e por aquelas pessoas ${ }^{70}$.

\footnotetext{
${ }^{70}$ Parafraseando Michel Foucault no artigo “O que é a Crítica?”, constante das referências bibliográficas.
} 


\section{Referências bibliográficas}

AGESTA, Luis Sánchez. In: SILVA, Benedicto (Coord.). Dicionário de ciências sociais. Rio de Janeiro: Fundação Getúlio Vargas, 1986.

ALVES, Nilda. Decifrando o pergaminho - o cotidiano das escolas nas lógicas das redes cotidianas. In: OLIVEIRA, Inês Barbosa de; ALVES, Nilda (Orgs.). Pesquisas no/do cotidiano das escolas - sobre redes de saberes. Rio de Janeiro: DP\&A, 2002, p. 13-38.

ARAÚJO, Ulisses F. Assembléia escolar - um caminho para a resolução de conflitos. São Paulo: Moderna, $1^{\mathrm{a}}$ ed., 2004.

ARENDT, Hannah. Da revolução. São Paulo: Ática; Universidade de Brasília, 1988.

A condição humana. Rio de Janeiro: Forense, 10ª ed., 2004.

BAUMAN, Zygmunt. Em busca da política. Rio de Janeiro: Jorge Zahar, 2000.

Modernidade líquida. Rio de Janeiro: Jorge Zahar, 2001.

BOBBIO, Norberto; MATTEUCCI, Nicola; GIANFRANCO, Pasquino. Dicionário de política. 5 ed. São Paulo: Imprensa Oficial SP; Universidade de Brasília, 1986.

CERTEAU, Michel. A operação historiográfica. In: A escrita da história. Rio de Janeiro: Forense, 2006.

DELGADO, Lucília de Almeida Neves. História oral: memória, tempo, identidades. Belo Horizonte: Autêntica, 2006.

FERREIRA, Marieta de Moraes. Desafios e dilemas da história oral nos anos 90: o caso do Brasil. História oral, n. ${ }^{\circ}$ 1, 1998, p. 19-30.

História, tempo presente e história oral. Topoi, dez. 2002, p. 314-332.

FOUCAULT, Michel. O que é a crítica. In: Cadernos da FFC, v. 9, n. ${ }^{\circ}$ 1, 2000. Faculdade de Filosofia e Ciências, UNESP Marília. 
O sujeito e o poder. In: RABINOW, Paul; DREYFUS, Hubert. Michel Foucault: Uma trajetória filosófica. Para além do estruturalismo e da hermenêutica. São Paulo: Forense, 1995.

. Soberania e disciplina. In: . Microfísica do Poder. Rio de Janeiro, Graal, 1995. . Método. In: História da sexualidade. A vontade de saber. Vol. I. Rio de Janeiro: Graal, 6ª ed., 1985.

HALL, Stuart. A identidade cultural na pós-modernidade. Rio de Janeiro: DP\&A, 2005.

JOHNSON, Allan G. Dicionário de sociologia: guia prático da linguagem sociológica. Rio de Janeiro: Jorge Zahar, 1997.

JOUTARD, Phillipe. História oral: balanço da metodologia e da produção nos últimos 25 anos. In: FERREIRA, Marieta de Moraes; AMADO, Janaína (Orgs.). Usos e abusos da história oral. Rio de Janeiro: Fundação Getúlio Vargas, 2005, p. 43-62.

MATE, Cecília Hanna. O coordenador pedagógico e as relações de poder na escola. São Paulo: Loyola, 2003.

Reformas de ensino e currículo: problematizando inovações nas práticas pedagógicas. LAZZARI, R. (Org.). Trajetórias e perspectivas da formação de educadores. São Paulo: Ed. UNESP, 2004.

NORA, Pierre. Entre memória e história: a problemática dos lugares. Projeto História. São Paulo (10): 7-28, dez. 1993.

OLIVEIRA, Inês Barbosa de (Org.). A democracia no cotidiano da escola. Rio de Janeiro: DP\&A; SEPE, 1999.

PUIG, Josep et al. Democracia e participação escolar. São Paulo: Moderna, 2000.

REVISTA da Faculdade de Educação. Resolução 118. São Paulo, jan./jun. 1984, p. 137.

REZENDE, Maria José de. A transição como forma de dominação política: o Brasil na era da abertura (1980 a 1984). 1991. Dissertação (Mestrado). PUC, São Paulo, 1991.

RIBEIRO, Sônia. Uma proposta democrática de educação. Nos meandros da máquina administrativa: a implantação e abandono de um projeto. 1992. Dissertação (Mestrado). PUC, São Paulo, 1992. 
ROUSSO, Henry. A memória não é mais o que era. In: FERREIRA, Marieta de Moraes; AMADO, Janaína (Org.). Usos e abusos da história oral. Rio de Janeiro: Fundação Getúlio Vargas, 2005, p. 92-101.

SADER, Eder. Quando novos personagens entram em cena: experiências e lutas dos trabalhadores da grande São Paulo (1970 a 1980). 2ª ed. Rio de Janeiro: Paz e Terra, 1995.

SAMUEL, Raphael. Teatros da memória. Projeto História. São Paulo (14): 41-81, fev. 1997.

SANTOS, Ediógenes Aragão. Participação, autonomia e co-gestão na escola pública. Cadernos de Pesquisa. São Paulo: Fundação Carlos Chagas, n. 68, 1989, p. 99-105.

SEIXAS, Jacy Alves de. Percursos de memórias em terras de história: problemáticas atuais. In: BRESCIANI, Stella; NAXARA, Márcia (Orgs.). Memória e (res)sentimento, indagações sobre uma questão sensível. Campinas: Editora da Unicamp, 2001.

SINGER, Helena. República de crianças - Sobre experiências escolares de resistência. São Paulo: HUCITEC, 1997.

SJOBERG, Gideon. In: SILVA, Benedicto (Coord.). Dicionário de ciências sociais. Rio de Janeiro: Fundação Getúlio Vargas, 1986.

SKIDMORE, Thomas. Brasil: de Castelo a Tancredo, 1964 - 1985. $8^{\text {a }}$ ed. Rio de Janeiro: Paz e Terra, 2004.

SOUZA, Aparecida Neri de. Sou professor, sim senhor!: representações do trabalho docente. Campinas: Papirus, 1996.

TEIXEIRA, Beatriz de Basto. Por uma escola democrática: colegiado, currículo e comunidade. 2000. Tese (Doutorado). FEUSP, Universidade de São Paulo, São Paulo, 2000.

THOMSON, Alistar; FRISCH, Michael; HAMILTON, Paula. Os debates sobre memória e história: alguns aspectos internacionais. In: FERREIRA, Marieta de Moraes; AMADO, Janaína (Orgs.). Usos e abusos da história oral. Rio de Janeiro: Fundação Getúlio Vargas, 2005, p. 63-91.

Recompondo a memória: questões sobre a relação entre a história oral e as memórias. Projeto História, n. 15, abr. 1997, p. 51-84.

VILANOVA, Mercedes. La historia sin adjetivos con fuentes orales y la historia del presente. História oral, n. 1, 1998, p. 31-42. 
Anexo I - Programa da Semana de Arte - página 01

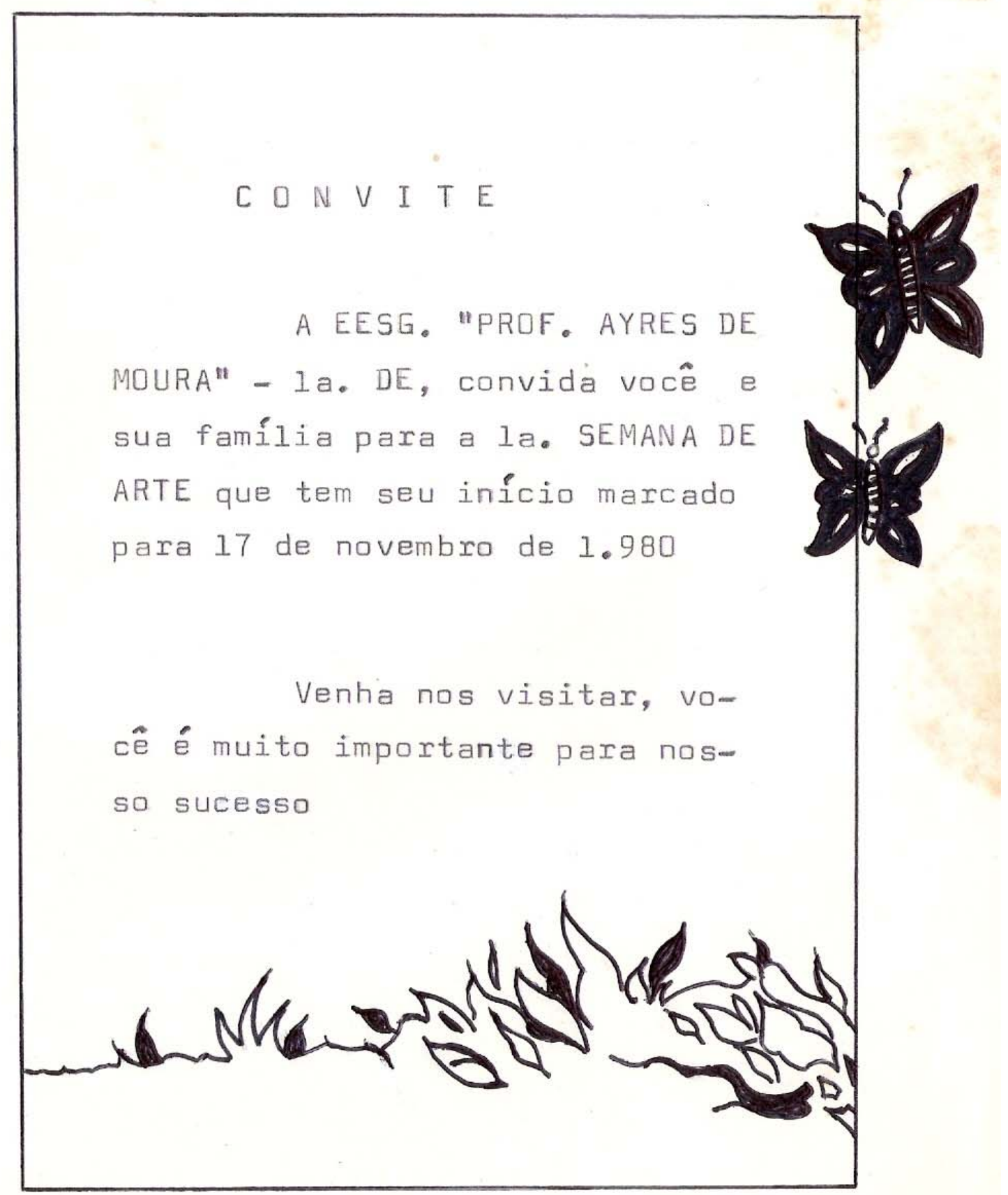




\section{Anexo I - Programa da Semana de Arte - página 02}

CONFERENCIAS:

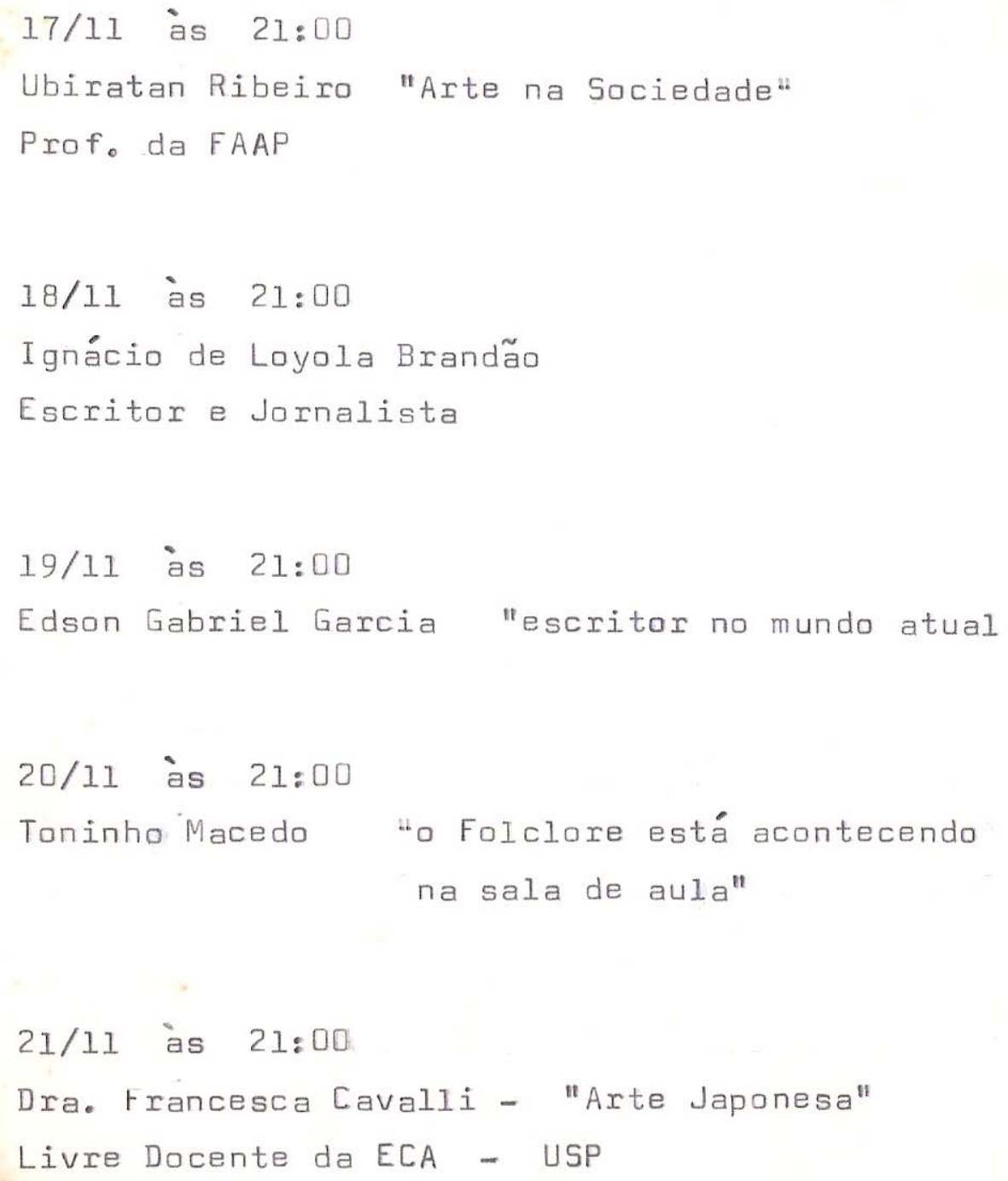




\section{Anexo I - Programa da Semana de Arte - página 03}

PROGRAMA

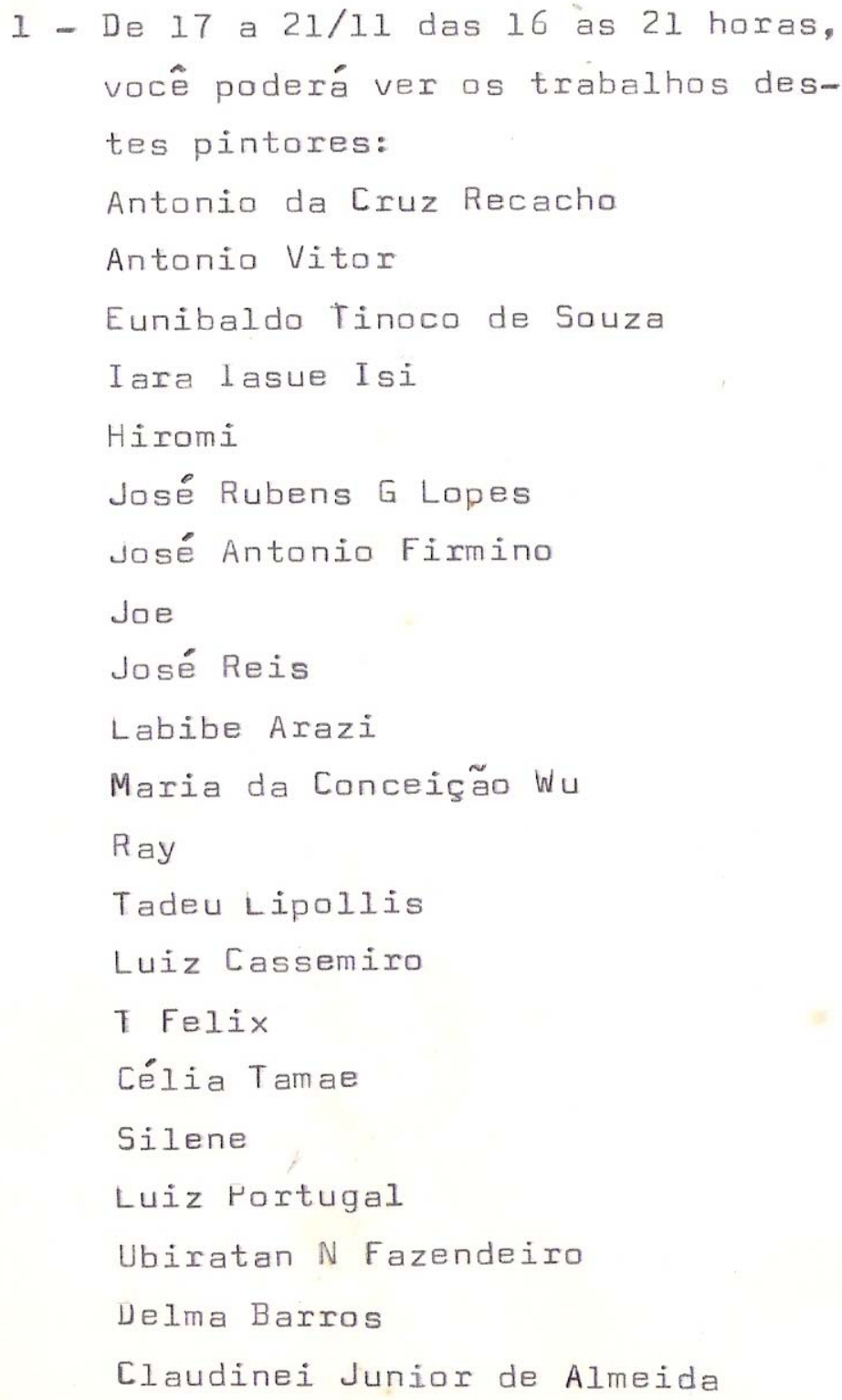


Anexo I - Programa da Semana de Arte - página 04

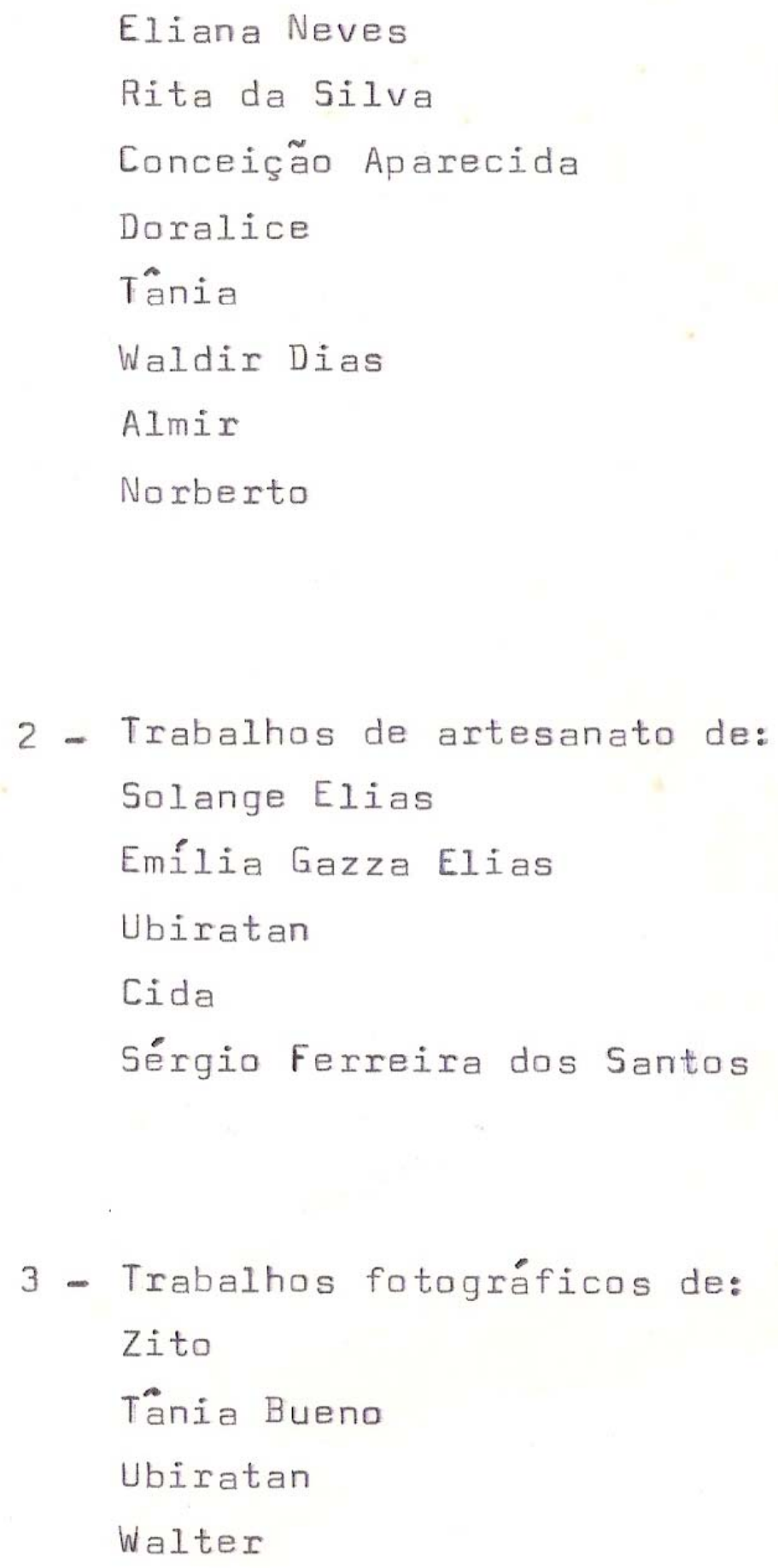




\title{
Anexo II- Documento número 01 - página 01
}

\author{
DOCUMENTO DE TRABALHO - Nº1
}

Este é um documento em que se expõem algumas opiniões sobre aspectos da nossa situação Educacional. Muitas dessas opiniões já foram ventiladas na Proposta Montoro sobre Educação. A razão para retomá-las e ampliá-las neste documento é a de promover o seu exame sistemático por todos os integrantes do magistério. Desse exame e das discussões que se travarem, espera-se que algumas idéias aqui apenas afloradas, transformem-se em projetos específicos de ação. Se isso acontecer, teremos reativado a única fonte legitima para gerar mudanças na situação educacional paulista: o diálogo, há tempo esquecido, dentre os que se ocupam do ensino em todos os níveis.

Contudo, a convocação ao dialogo não exonera a Administração da responsabilidade de indicar prioridade e de sugerir direções. Trata-se apenas de um balizamento da discussão com o objetivo de impedir que o esforço de participação se espraie infecundamente numa multiplicidade caótica de direções.

Se há algo que marca profundamente a educação brasileira é a quase completa ausência de uma política Educacional. Nestes anos todos, temos vivido da improvisação; não poucas vezes, ao sabor de interesses em conflito com os reais interesses da coletividade. No entanto, o vazio de idéias tem sido preenchido por uma avalancha de legislação e de providências administrativas que sufoca a desejável iniciativa criadora das escolas e favorece o embuste educacional. Como ingrediente usual desse embuste, têm aparecido, aqui e ali, "planos de educação" que - sem idéias norteadoras sobre os rumos da educação - nada mais representam do que projeções numéricas ufanistas e irreais, quando não fraudulentas.

Como resultados dessa desorientação geral, o sistema educacional brasileiro de $1^{\circ}$ e $2^{\circ}$ graus (se é que se pode falar em sistema) apresenta-se atualmente com duas características indesejáveis: a insuficiência numérica de vagas (principalmente do $2^{\circ}$ grau) e a deficiência qualitativa (marcando ambos os graus). Não há escola para todos e a que existe, muitas vezes não satisfaz.

Em face dessa situação, o que se reclama, de um Governo que pretenda representar os interesses do povo, é a clara formulação de uma Política de Educação que ordene providências e racionalize os gastos educacionais a partir de rumos cuja fixação reflita a discussão ampla e a participação ativa, como convém ao regime democrático.

Para desencadear essa discussão, é preciso que o Governo explicite algumas idéias preliminares sobre a situação do ensino. Sem elas, nenhuma discussão será fecunda e a convocação à participação dos segmentos sociais interessados será antes um simples convite à agitação cansativa dos impotentes. O governo não tem idéias prontas e irreformáveis, mas, por outro lado, não terá também a leviandade de abdicar de sua responsabilidade de indicar rumos e de apontar possíveis soluções. 


\section{Anexo II- Documento número 01 - página 02}

Qualidade de ensino: Nos últimos dez ou doze anos, um dos temas mais constantes na educação brasileira e, especialmente, na de São Paulo, tem sido o da qualidade do ensino público. E o ponto de convergência de todas as opiniões é o reconhecimento da má qualidade desse ensino. A concordância é mais ampla ainda, pois, aponta também as raízes do problema: a má qualidade do ensino público deve-se a sua precipitada e indevida expansão quantitativa. Num nível de argumentação aparentemente mais técnico, o raciocínio que se faz é o seguinte: confundiu-se democratização do ensino com a simples expansão numérica de vagas e isso provocou a deterioração do padrão de ensino oferecido. Tudo parece muito claro e muito simples nesse raciocínio; daí a ampla concordância em torno dessa idéia. Para reforçá-la ainda mais, veio contribuir o que há pouco a imprensa difundiu sobre opiniões de um grupo de educadores americanos a respeito da situação do ensino público nos Estados Unidos (The Paideia Proposal), com especial destaque para o seguinte: "a promessa democrática de igualdade de oportunidades educacionais, quando meio cumprida, é pior do que a promessa quebrada. É um ideal traído. A igualdade de oportunidades educacionais não é de fato realizada, se não significar mais do que manter todas as crianças em escolas públicas pelo mesmo número de horas, dias e anos. (...) $O$ (propósito democrático) fracassa porque ele terá alcançado apenas a mesma quantidade de escolarização pública, não a mesma qualidade."

O trecho citado seria subscrito com unção pelos que aqui no Brasil também vêem, na expansão das vagas, a causa da ma qualidade de ensino.

No entanto, uma análise mais serena da situação revelará que as coisas não são assim tão simples, e que o raciocínio a cima merece alguns reparos:

a) O que se chama de má qualidade de ensino não é fenômeno tão recente quanto o da expansão das vagas. As escassas análises e a lacunosa documentação da história da educação brasileira sempre constataram ou presumiram o fato. A grande diferença entre a situação e situações passadas parece então consistir, principalmente em que hoje existe má escola para a maioria. (pelo menos no $1^{\circ} \mathrm{grau}$ ), e, antigamente, havia má escola para poucos. A ser assim, não parece, pois, que tenha ocorrido uma deterioração, mas uma simples expansão da deterioração. Daqueles que pensam diferentemente (e são quase todos) basta que se indague o seguinte: em que períodos passados a escola pública brasileira foi de boa qualidade? Não há resposta convincente e objetiva para essa questão, mas aqueles que insistirem em dá-la, perguntemos ainda: e quantas eram essas "boas" escolas? Ninguém; amante da verdade histórica poderá, para qualquer período passado, apontar numero que ultrapasse algumas dezenas. 


\section{Anexo II- Documento número 01 - página 03}

b) É claro que se pode contra-argumentar dizendo que se o ensino público brasileiro já não era bom, acabou piorando com a desastrada expansão dos últimos quinze anos. A réplica a esse contra argumento é banal e pode ser formulada, novamente, por uma questão: piorou para quem? E a resposta honesta só poderá ser a de que piora apenas atingiu àqueles que tinham acesso à escassa escola pública brasileira, isto é, a diminuta parcela de privilegiados, membros do "patriarcado" brasileiro. O restante, a imensa maioria do povo brasileiro, não tinha escola. Então, para os desatendidos, a escola que veio, mesmo ruim, foi uma melhoria. A má-fé, algumas vezes, e a ingenuidade, quase sempre, poderão insistir dizendo que não há melhoria nenhuma porque a educação que aí está é um engodo e não prepara para nada. É difícil aceitar essa conclusão, porque nenhum principio de ética ou de pedagogia poderia justificar a idéia de que é preferível não oferecer educação nenhuma, se não for possível oferecê-la excelente. Seria aceitar como bandeira a idéia fascista defendida por Gentile na década de 20 "poucas escolas, mas boas".

Em resumo, a escola pública brasileira de $1^{\circ}$ grau sempre foi de má qualidade e escassa; mas hoje, pelo menos em São Paulo, ela atinge a grande maioria. Que fazer? Será que a alternativa de ensino bom para poucos seja ensino ruim para todos? Não acreditamos que assim seja. Não aceitamos a conclusão dos educadores americanos (The Paideia Proposal), segundo a qual, em matéria de educação, a promessa democrática, quando meio cumprida, seja pior do que a promessa quebrada. Nada pode ser pior do que acrescentar, ao drama da parte mais sofrida da população, a ausência de vagas na escola pública. É preciso melhorar a qualidade do ensino público, mas sob protesto podemos sonegá-lo à grande maioria.

Planos de melhoria do ensino: Nesse quadro de atendimento da grande maioria do ensino de $1^{\circ}$ grau, a questão da qualidade ganhou um relevo incomum que não havia quando a rede de escolas era menos extensa. O descaso pelo magistério e pela escola como instituição educativa fez com que a democratização do acesso se transformasse, em poucos anos, numa fraude pedagógica. Porque, evidentemente é inadmissível que a democratização do ensino se esgote no esforço do pleno atendimento. É preciso que esse esforço seja completado por medidas visando à melhoria do ensino. № entanto, temos dúvida de que - segundo a visão tecnocrática - a melhoria seja alcançável apenas por uma intensificação do aperfeiçoamento do pessoal docente por meio de cursos promovidos por órgãos regionais ou centrais, como usualmente é feito. Em primeiro lugar, porque esses cursos dão uma ênfase exclusivamente metodológica à questão da melhoria do ensino, e, em segundo, porque, para freqüentá-los, desloca-se o professor da escola (centro dos problemas profissionais que vive). E, principalmente porque, hoje, nas dimensões em que o problema educacional foi agravado, a questão da melhoria do ensino não é mais simples questão técnica, mas sobretudo, de alto interesse público. 


\section{Anexo II- Documento número 01 - página 04}

Pretender que a mera promoção de cursos de atualização metodológica seja capaz de melhorar a qualidade do ensino é, assim, insistir em resolver um problema escolar-social concreto por meio de uma operação duplamente abstrata. Nenhuma metodologia, abstratamente formulada e ensinada, dará respostas aos problemas que o professor vive cotidianamente na sua escola, e nem adianta reunir algumas dezenas de professores de uma mesma disciplina como se eles fossem um grupo de pessoas que enfrentam os mesmos problemas. Cada escola tem características pedagógicosociais irredutíveis quando se trata de buscar soluções para os problemas que vive. A realidade de cada escola - não buscada por meio de inúteis e pretensiosas tentativas de "diagnóstico" - mas tal como é sentida e vivenciada por alunos, pais e professores, é o único ponto de partida para um real e adequado esforço de melhoria. Nessas condições é preciso que no âmbito de cada escola - e com a colaboração de todos os recursos da comunidade - sejam explicitados os problemas que impedem a melhoria do ensino e formuladas as suas possíveis soluções. Cada escola deve, pois, ter o seu próprio plano de melhoria, que não será mais do que o seu próprio esforço em corrigir as distorções e os desacertos técnicos, bem como em remover ou atenuar os impedimentos sócioeconômicos de origem extra-escolar que embaraçam uma ação educativa eficaz. Em face desse quadro, a ação de órgãos centrais da Secretaria da Educação deve ser definida não em função de planos de melhoria gerais e abstratos a serem impostos a toda a rede de escolas, mas dirigida exclusivamente à criação de condições de sustentação e apoio ao auto-esforço insubstituível de cada escola na busca da superação das suas deficiências. Para essa sustentação e apoio, não só os órgãos da Secretaria da Educação, devem ser mobilizados, mas todos os recursos pessoais e institucionais da comunidade, de modo que, numa ação conjunta com a escola, sejam identificados e enfrentados os obstáculos que embaraçam a ação educativa.

Pode-se argumentar contra essa visão, ponderando que ela é não-realista e que as escolas não serão capazes de se organizar para perceber e superar as próprias deficiências. Se isso for verdade, é também ilusão imaginar que tal escola - incapaz de auto-consciência e de auto-esforço - venha a se beneficiar efetivamente pela imposição de qualquer plano regional ou central de melhoria de ensino.

Situação do magistério: As análises que concluem pela má qualidade do ensino publico e apontam como sua causa a expansão numérica das vagas têm silenciado sobre outros fatores, dentre os quais sobreleva um que é talvez o mais importante: a degradação social e profissional que o magistério vem sendo submetido nos últimos anos. Nenhuma melhoria da escola se resume na construção de prédios adequados ou na implantação de novos métodos e técnicas. É preciso, antes de mais nada, convocar o magistério para essa tarefa. Mas, nenhum governo terá 


\section{Anexo II- Documento número 01 - página 05}

idoneidade para fazer essa convocação, se não der demonstração inequívoca de que assume o compromisso de restabelecer a dignidade do professor. Não se melhora o ensino degradando os seus responsáveis diretos. É uma insensatez o descaso com que essa questão tem sido tratada. É uma ilusão irresponsável esperar que uma pessoa humilhada e ressentida possa incutir nos nossos filhos uma visão sadia da vida e do futuro. Não se trata apenas de remuneração mais justa, embora esta seja indispensável. É preciso extirpar radicalmente a interferência da política de clientela nas decisões relativas às condições de trabalho e de carreira do magistério. A carreira do magistério não pode mais ser apenas uma sucessão de fadigas e frustrações, das quais só se escapa pela bajulação e pelo servilismo. É preciso que a progressão funcional no cargo ou função-atividade seja a justa retribuição do mérito e do esforço. É preciso que a ascensão na carreira não tenha como preço o aviltamento moral e profissional. E para impedir essa distorção do serviço público na área da Educação é também necessário que as entidades representativas do magistério sejam consideradas pela administração como interlocutores e válidos no insubstituível diálogo que deve preceder as principais decisões da Secretaria da Educação.

Ensino de $1^{\circ}$ Grau: Não há autêntica política de Educação sem que se afirme claramente o que se pretende em cada grau de ensino. Em face dos objetivos gerais, já fixados na legislação para cada grau de ensino, é necessário ainda que a Administração estabeleça as coordenadas do esforço para o seu alcance.

No entanto, com relação a esse ponto, a situação do ensino de $1^{\circ}$ grau é caótica. A Lei 5.692/71 instituiu o ensino de oito anos, mas, ainda hoje, quase doze anos passados, não se sabe o que fazer nesse grau de ensino. Em todo esse tempo não se formulou nenhum modelo, nenhuma idéia diretora do que deveria ser uma escola de oito anos. Os antigos ensino primário e ginasial foram simplesmente justapostos e nada mais se fez e nem foram prestigiados os isolados e espontâneos esforços de algumas poucas escolas. Principalmente em São Paulo, onde a tímida tentativa do Grupo Escolar-Ginásio poderia eventualmente ter oferecido subsídios para uma escolaridade oito anos organicamente estruturada, nada mais se fez depois da Lei 5.692/71, e o que havia foi desfeito. Por isso, não é exagero falar de caos.

Os antigos ensino primário e ginasial alcançam alunos em fases de desenvolvimento distintas que nenhuma organização escolar deveria desconhecer. $\mathrm{Na}$ ausência de uma concepção orientadora de como uma escola de oito anos deveria enfrentar a nova situação, nada ocorreu em termos de preparação de professores e diretores. Em conseqüência disso, a atual escola de oito anos e uma mentira pedagógica. Dentro dela, os antigos ensino primário e ginasial sobrevivem com seus problemas agravados por uma convivência sem integração. A evidência maior dessa situação está no fato de que no ensino de $1^{\circ}$ grau os mais graves problemas de repetência e evasão localizam-se, principalmente, na $1^{\mathrm{a}}$ e na $5^{\mathrm{a}}$ séries. É preciso que recursos 


\section{Anexo II- Documento número 01 - página 06}

humanos extraordinários sejam mobilizados para atenuar os efeitos desses pontos de estrangulamento. Se o aumento da jornada de trabalho dos professores não tivesse sido usada como simples expediente para mascarar a diminuição crescente do poder aquisitivo do salário do magistério de $1^{\circ} \mathrm{grau}$, talvez se pudesse, aproveitando o tirocínio dessa categoria profissional, reduzir substancialmente a perda humana, social e econômica que a repetência representa utilizando-se os professores em jornada integral como colaboradores de colegas menos experientes.

$\mathrm{Na}$ omissão com que o assunto foi tratado não se levou em conta, para enfrentar os desafios novos de uma escola de oito anos, nem mesmo o rico acervo de experiência de professores e de diretores diretamente envolvidos no processo. Poucos foram consultados, não se fez nenhum estudo em profundidade e nem mesmo se levou o problema à consideração dos cursos médio e superior de formação de professores. Na designação anódina dos professores em I, II e III perderam-se também ricas tradições de trabalho e encontrou-se o pretexto para que persistissem distinções salariais injustas, muito pouco atenuadas pela atribuição de pontos por habilitações específicas de grau superior.

Ensino de $2^{\circ} \mathrm{Grau}:$ No ensino de $2^{\circ} \mathrm{grau}$, a desorientação é maior ainda. A última reforma desse grau de ensino (Lei 5.692/71), ao arrepio das tendências históricas da educação brasileira, pretendeu a profissionalização maciça no ensino médio, a pretexto de uma necessidade nacional de mão-de-obra nesse nivelo No entanto, Luiz Cunha mostrou insistentemente que essa alteração foi feita sem nenhum estudo em escala nacional para diagnóstico dessa alegada necessidade. Mas ainda, nem mesmo há condições objetivas para estabelecer relações interessantes e fecundas entre eventuais necessidades de mão-de-obra nesse nível e uma política de formação de pessoal, em termos nacionais. Mais uma vez prevaleceu a solução e simplista dos tecnocratas. O resultado aí está: gerações de jovens sacrificados na sua formação geral por um arremedo de ensino profissionalizante de que ninguém precisava e a que ninguém serviu. Pelo menos três graves problemas foram cometidos nessa reforma: 1) a precoce e injusta destinação profissional de jovens que ainda estavam a meio de sua formação intelectual; 2) o abandono do superior objetivo da escola de $2^{\circ}$ grau que é a formação para uma plena cidadania, a partir de uma extravagante concepção tecnocrática a serviço de interesses imediatistas e mal detectados, e 3) a descaracterização do ensino normal de tão viva tradição em São Paulo, e que foi transformado numa confusa e ineficiente "habilitação para o magistério".

Em São Paulo, esses erros tiveram ainda maior gravidade porque na implantação da reforma abandonou-se a idéia sem nenhum estudo para aferir a sua validade de um colégio integrado sobre o qual poderia acrescentar-se um esforço profissionalizante pós-colegial, aproveitando-se assim, até mesmo, a própria rede de ensino superior e a capacidade de ensino das próprias empresas. 


\section{Anexo II- Documento número 01 - página 07}

Hoje, com a consciência que temos dos erros que se cometeram, implicitamente admitidos pela promulgação Lei $7.044 / 82$, será possível repensar a escola de $2^{\circ}$ grau como a verdadeira escola de uma cidadania plena, na linha da sua autêntica vocação histórica e repensar também, o ensino profissionalizante nos seus múltiplos aspectos e possibilidades, sem reduzi-lo à vala comum em que caiu e se descaracterizou todo o ensino de $2^{\circ} \mathrm{Grau}$.

Autonomia da escola: Desde a Lei 4.024/61 até a Lei 5.692/71 e também através de inúmeros pareceres e resoluções dos conselhos de Educação, vem se insistindo na autonomia da escola enquanto instituição educativa. Nem poderia ser de outro modo, porque a tarefa educativa tem como pressuposto ético a autonomia de quem educa. Sonegada esta condição, a escola perde a sua autêntica feição educativa e transforma-se em instrumento de doutrinação.

No entanto, infelizmente e não obstante as alegações em contrário, as nossas escolas de $1^{\circ}$ e $2^{\circ}$ Graus jamais tiveram a autonomia que a lei lhes conferiu. Amordaçados nos "provisórios" regimentos únicos, as escolas foram castradas na sua autêntica função educativa porque diretores e professores são simples funcionários burocráticos dos quais não se exige que eduquem, mas que cumpram ordens. Em nome de uma alegada necessidade de disciplinar "enquanto" as escolas não estiverem em condições de se organizar, o que temos não é a sadia diversidade do que é mesmo desigual, mas a aplastante uniformidade que pretende eliminar a possibilidade do erro, e que de fato elimina a responsabilidade. Não pode ser responsável perante o seu próprio trabalho quem não tem nenhuma autonomia de decisão.

É preciso que as escolas públicas tenham a autonomia que a lei lhes confere. Não mais é possível que, nesse ponto, as escolas públicas sejam discriminadas das escolas particulares, cuja autonomia legal é respeitada. Já dizia Bacon que a verdade brotará mais facilmente do erro do que da confusão. É isso o que esperamos. As escolas públicas encontrarão o seu verdadeiro caminho, apesar dos eventuais erros, se eliminarmos a imensa e confusa interferência tecnocrática e administrativa que até agora vem tolhendo a sua ação e o seu relacionamento com as comunidades a que pertencem. Cabe a administração, nesse particular a ação orientadora e não a emasculação das potencialidades criativas.

Não nos iludamos, porém, com a simples conquista da autonomia administrativa e didática fixada num regimento próprio. Este é apenas um momento de um projeto pedagógico mais amplo, que é a verdadeira razão de ser de uma escola democrática.

Como dissemos, anteriormente, a tarefa educativa tem como pressuposto ético a autonomia de quem educa. Esta autonomia do educador tem na autonomia regimental da escola apenas uma das condições de seu exercício, e não pode ser com ela confundida. A autonomia do educador - por paradoxal que possa parecer - é, hoje, num momento histórico de busca democrática, um comprometimento total com o ideal democrático de educação.

Nessas condições, quando se insiste na autonomia da escola como uma das condições 


\section{Anexo II- Documento número 01 - página 08}

de melhoria de ensino, não podemos reduzir essa melhoria a um ensino simplesmente mais eficiente no seu conteúdo estritamente escolar. Para isso, não seria preciso reivindicar uma escola autônoma, até mesmo uma escola fortemente presa a regulamentos rígidos e impostos seria capaz de ser uma boa escola.

O fundamental é que a autonomia de nossas escolas públicas esteja impregnada e constitua a base de uma tarefa educativa cuja excelência há de ser medida pela sua capacidade de instalar uma autêntica convivência democrática, e, por isso mesmo, de formar homens críticos, livres e criativos até mesmo a partir de condições sociais, políticas e econômicas adversas.

Por isso, é preciso não perder de vista que a busca da autonomia da escola não se alcança com definição de uma nova ordenação administrativa, mas, essencialmente, pela explicitação de um ideal de educação que permita uma nova e democrática ordenação pedagógica das relações escolares.

Observação final: é preciso não se perder de vista que este documento é apenas o primeiro de uma série, e que quanto aos assuntos focalizados não se pretendeu mais do que uma sugestão de prioridades.

Outros documentos trarão à discussão a questão da pré-escola, do livro escolar, dos cursos noturnos, dos Conselhos Municipais de Educação, da merenda escolar, da assistência médico-odontológica ao escolar, etc. 


\section{Anexo III - Resoluções do I Congresso - 1981 - Capa}

I CONGRESSO DA ESCOLA ESTADUAL DE $2^{\circ}$ GPAU PROF, AVRES DE MOURA $29 / 30$ DE JUNHO E T\% DE JULHO DE 1983

\section{PELATOR IO}

INTRODUCẲO

PROPOSTAS RPROVADAS NAS PLENÁRTAS

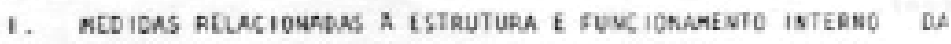
Escona
1.1. Diregèe
1.2. Funtienanente
1.3. Segurange

11. MEDIDAS RELACIOUACAS A EUESTRO CUEAICUCAR I DIOATICO-VEDNGO cise

11.1. Curriculo

11,2 , Questëes didätico-pedagingicas

11.9. Questỗes relacionadas à avaliação

11.4. Questč̀s ralacionadas h̀ recuparaçẩo

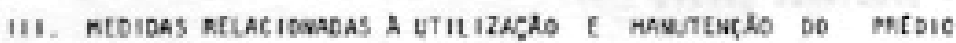
ESCCLAR.

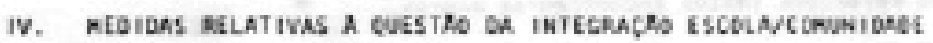

v. comissoes executivas 


\section{Anexo III - Resoluções do I Congresso - 1981 - página 01}

INTEODUCAO

A partir do Decweeste de Trabathe af 1, de secrotbrle de

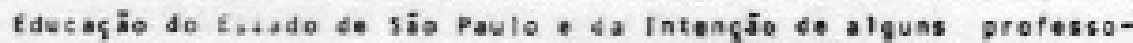
res da Eacela Eatadeal de Segunde Grau Prof. Ayros do Moura [eEpam] da dicueir os preblenas deata sacele, fol sprovada - durante raz ntäo de corpo decente cee a direçäe de escela e I revalla desta -

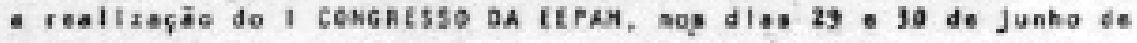
1983.

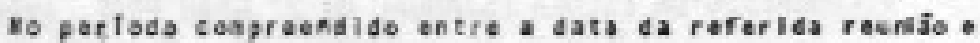
- da realiaçäe do Congresso, feran distribufidos tektes concernontes i questio educaclonal para slunes, profeusores. funcionirios. direçäo(*). Eate fato grepleloa Intenso discussäo no escola, incle sire coususpensëo da natérla. ea sala de oula, por algens professores que passefan a discutir as textos juatanente con os alunos. hessalse-se que os dols últimos textes distribufios foras produte

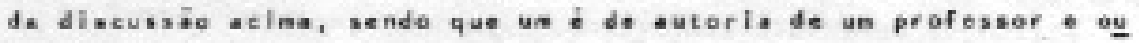
tro de ua oluao.

Conconltantenente. este processo de discussóo. Coeita-

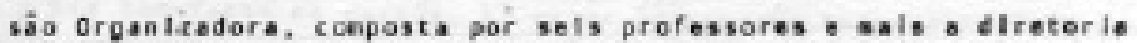
do ceatro CIvico Ratudant|l (10 slumas), encanlnhou toda o 'proces so de organlkaçio, divulgaçio esclarecinente do Congresso ea toda a escola, Inelusive cen anceneros o discussäe een of roprosontantes de classe des dols perfodos de funelonamente fartutino. ng turnol.

e laportanto sallentar que en todo processo de organilage

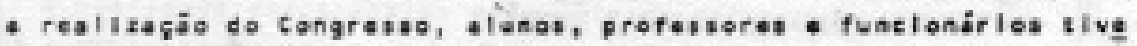
ran sua portleipecio garancida de forma lgualicdela.

De dla 29/06, os partlclpantes reuniran-se en pequenos gry pot (no mbximo compostojpor 15 eleneatos) ende fol olscutida. 'sesulate pouta:

1. AELACGAO PROFESSOR/ALUMO

- autoritarismo

- avallią̧áo

- eantevido

- prebleasa gerala

(*) Os referidos textos encontran-se mexos. 


\section{Anexo III - Resoluções do I Congresso - 1981 - página 02}

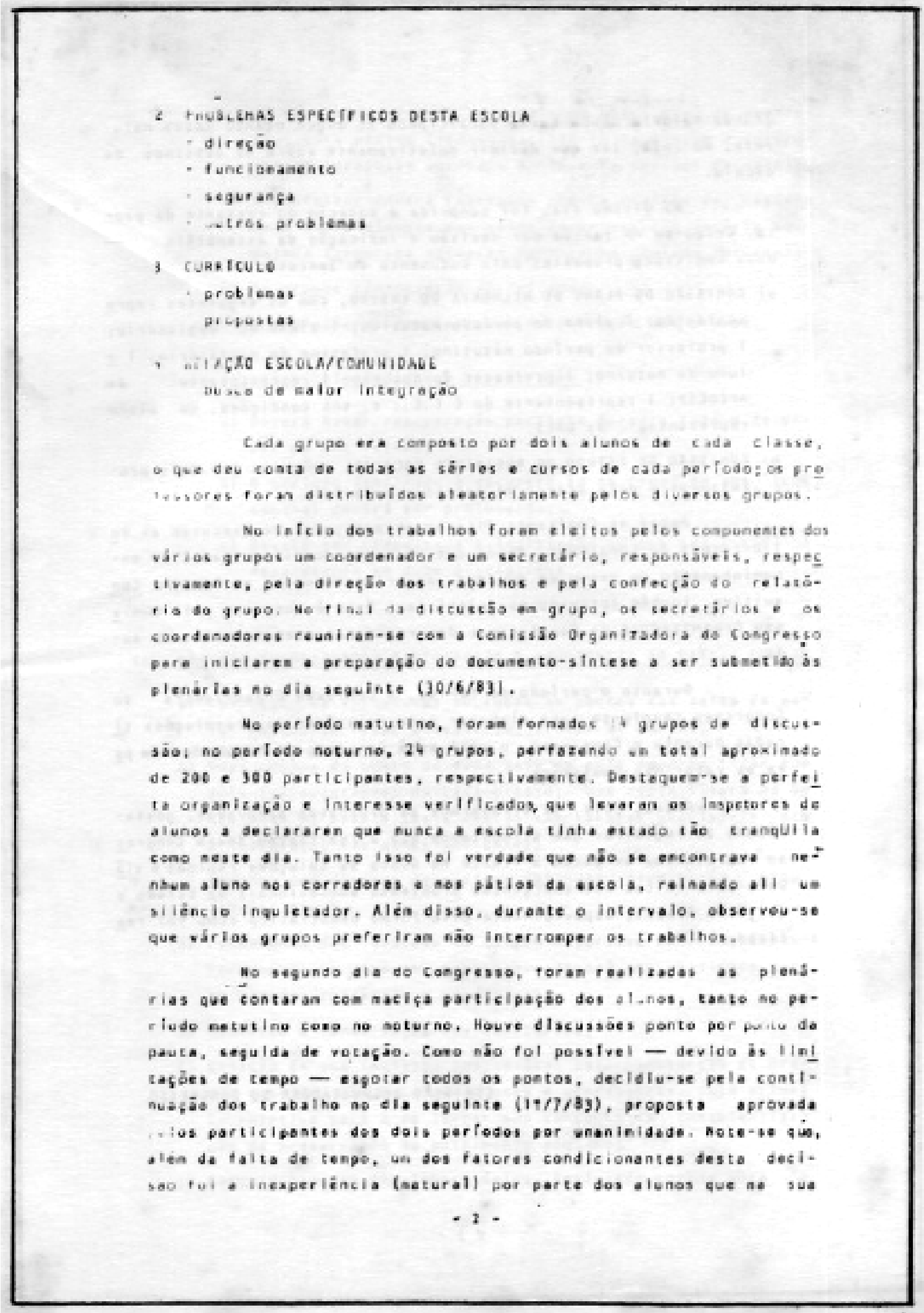




\section{Anexo III - Resoluções do I Congresso - 1981 - página 03}

grande malorta nunce herle particlpodo de alque svato dessa natureza, ou seja, ter que decidir coletivanente sabre as destinos da ascala.

Ko ütimo dia, fol sumprida a votagjo do rescante da pae-

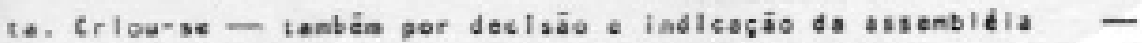
duas conissöes propostas"pelo Doceneato do Secretabiou

a) COHISSAO DO PLAND DE RELHOKIA DQ CMSINO, Con as segulaten repre

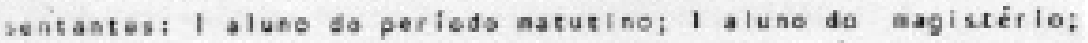
I professor do perlode satutine: I professor de nagistérlo: I A luao do noturno; 1 prefesser do noturnoz I resresestante da APEeESP; 1 representonte do C.C.E. ; $t$, sob cosdigöes, un aleno reproseatanez da UAES.

b) COSISSAD OE ESTUDO OO REGIHENTO ESCOLAK, conpOSta por dols professares e deis alenes da Canisäo anterier.

Anbas as camissēes ficaran encarrezades de cxecutar as de liberaçōes de Gengrasso, sendo que en casos de dificuldaces de en= coalnhoaento ou messa de düvidas, devecian fecerrer ao conselho coa cultiva. Eanbés eprovade nas pienírias. Esto É conposta pala Conís a oro Orgatiodora do Congresso e dos represestantes de salas de au

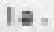

Durante o gerfodo de ferlas, Conlssio Drganlzadora da

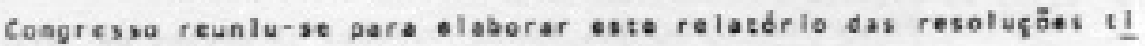
radas darante o Congresso, o qual esth servinde de documentobase pa ra as refacidab conlssöes.

Antes. pols, de arrolarnos as prepostas aprovadas, geater rlanos de reglstrar que acredtiomos que a realiaagäo deste congres

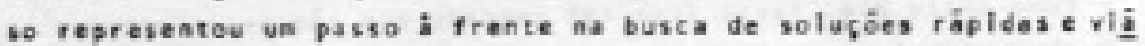
vel. pera eulitos dos emergantes probleas asucaclosals do Estado e

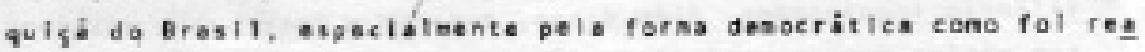
1 izade. 


\section{Anexo III - Resoluções do I Congresso - 1981 - página 04}

\section{PRDPOSTAS APEONLDAS NAS PIENÁRIAS DO \\ I CONGRESSO DA EESG PROF, AYAFS DE MOURA}

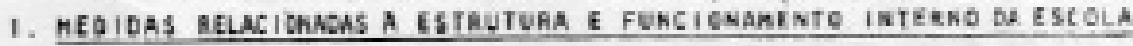

\section{1. piresion}

4] Encaeinberento do of astaucata do direter do escole Junto aes.örgäos competenles (preposta aprovada na plenjrlodo purfede do manhä):

b] Pesenga constance de diretor es escolo proturasdo sulor tategregáo eatre diresāo a alunes e encantrhando solucöes gara os problenas da escolo fproposta aprorada na plenärle de perfodo notwrnol;

c) atexar nos relotóríos do Conoresso a declarasajo dos pro fossores referente aos Incldentes ecartidos con assit tente de tregáa da escela na plenirta do perfodo notur ne do di. 30/6/B3.

\subsection{Funcianamente}

e) Hobo Iaterferäncle da adeinistragäo da escole nas ativi= dades desenvolvidos pelo C,C.E. garantindo sua eutonos.1.

b) Peranazinela de apenas un professor por diacipliae auran te tode ono letiro, Isto í, sue nbo haje frequentesmu daņ̧⿻: (renoģes/ingresses) durante o sno letivo:

e) A difeçäo da eceola deverj tomer aedidos mals enëralcss con as professopes que faltam constantenante:

d) Procurar factilter so mixiae o organlagio do norbirio dos professores. Hie de que nào felean;

e) Professores. Alunos deveräo respeltar o horärlo de entreda te prinelre aula con telerbacla de epenas der ninutes (proposta aprovada ne perfodo de manha):

f] Ea case de perdo de prove. as professeros nio deverbo exigir qualquer tlpo do otestado do oluno para que este

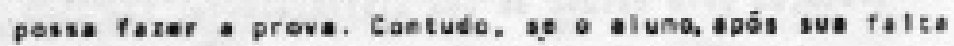
ne data earcade, continjer faltando outros dies, - epli 


\section{Anexo III - Resoluções do I Congresso - 1981 - página 05}

cagio de neva prova beri decidida entre o professer

a classe:

g) Dalung deveri ter a liberdade de poder ansistir outras eulas en seu hor brto vogo:

b) Os olunos teräo. 1iberdede de sofir da aula no monento ex que desejereat;

1) A. aulat werio iaserroupldas sonente en casos de grande necessidade:

j) Plancjer cor antecedincla de no $n / n i m o$ una senana as otividedes que envolvan a suspensiog de aula;

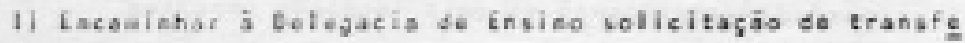
récla do capeonato colegial reallizado atualeente hes. is escela paca o tentro tspersiva da prefelitura;

n] Eacaninnar j Detegacla de Ensino solicleasajo para que os rentiass organiredas por esta nesea Delegacio nesta ebcola no perfoso da nanhj sejan transferidas para o pe r Tedo do tarde (propogte eeroveda ap periodo da nahbi).

a) Ho inleto do ano letivo, oplanajanenta deverb sef foito par professores e alunos (1934):

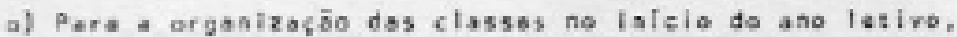
dever a ser abedeclao a critérlo de $\underline{15}$ alunos por clas. se. to waxine $(1994)$ :

p) Instalagau das salas-aablente (cada professor on una is la de aula par perfado) e estabeleclaenta de tenpo decerainaso para a transferincla bot alusos de una cala a outra $(1984)$;

q) Na confeçäo de harério do próxiag ano as oulas dobro= das deverjo sar pelvilegledab ofla do que so factilte * erganizagäo das Malas-amblentai

r) O hofberio de aulas deveri estar pronto at o final do primetro mề do ano letiro $(1984)$;

3) As cartelrinhas escolares o de passes deveröo estar i disposiçio dos alunos no tínal do prineiro nis letive (1986):

4) A biblioteca deveri ser reservado ua local adequado a sua reestruturagajo deverí sar efotuada atravis da con trategáo pelo Estedo de una blbliotecaria, bea cono te 


\section{Anexo III - Resoluções do I Congresso - 1981 - página 06}

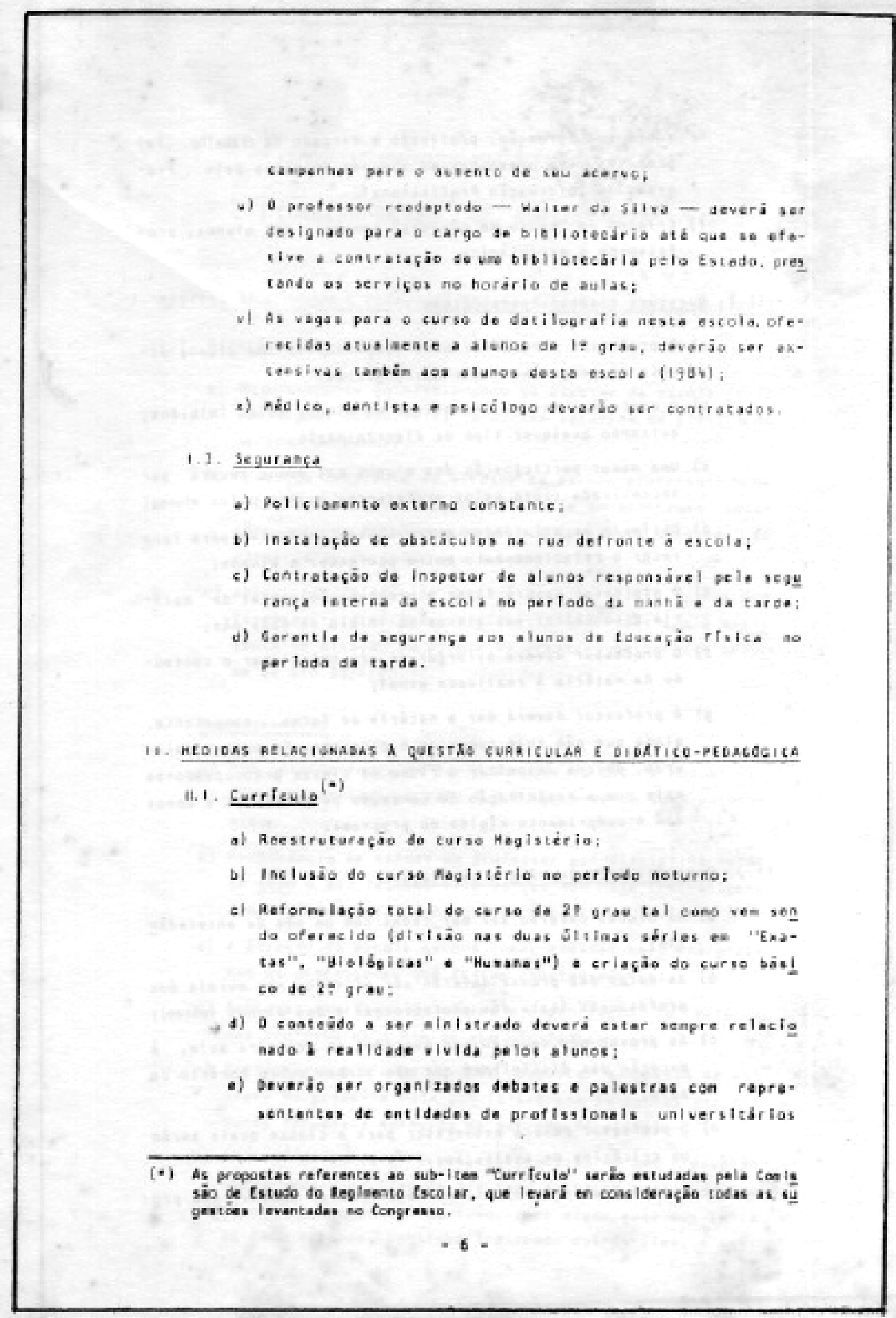




\section{Anexo III - Resoluções do I Congresso - 1981 - página 07}

sebre sua ferraçăo, profissäe e nercodo de trabsibo. Tal proposta visa praencher as lacunas delkadas pelo prograws te Infornogio Profisslenals

f) Criagio de "banco de dividas" corpaste per alunes, pros fessores e tatagíarias.

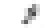

11.2. Queatcea d|dätleq-pedagögleas

4) a prafesser dever acr nels canpresnstro eov elunos ief=

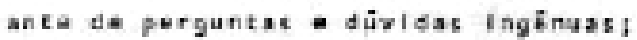

b) a professoe deverb lacenctuar os alunes nats leloides, evicando qualeuer tipo ta diateriminapäo;

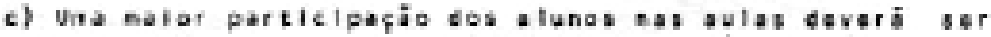
Ineenciroda ianto pelos professores quanto pelob alulow;

d) Estimulo bs etividades extra-clese lecleslue pera favo recer o relacionamente entre professor alueos:

-) o professor devers fazer a progranafa mensal da nacár fa c canusicar as olenos ne infele de codo ä́s;

f) D prefessor deverj esforgor-sepera felbeloabr o conteudo da nateria h realldade acual;

gl o professar daverb dor a satérl. de farne conpetente, a lada qua nio aja cungriso preqrana. En outras palavias, deveri respeltar o rltao da clese preocupandome sals con a assiallagie do contevido pelos alunos a renca con o cumpilinento rifido do pregrana.

\subsection{Qeastóes relacionadas is orallasäo}

-) As provas deverbo ger ner_cadas con un nễs de antecetén c1a:

b) As datas das provas deverjo ser afixades nos aurals dos professores (sole dos professores) E dos stunos (páteol;

c) As provas ä̈o deveräo ser masedas na primetira oula, j

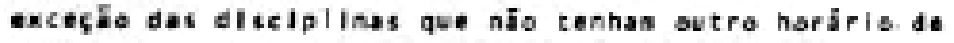

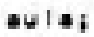

d) O professor deverb esclarecter para s classa quals, gefäo ov crltírles de avaltagáo,

e) Pore. ovoliagbo blnestral devert haver sonente and pro 


\section{Anexo III - Resoluções do I Congresso - 1981 - página 08}

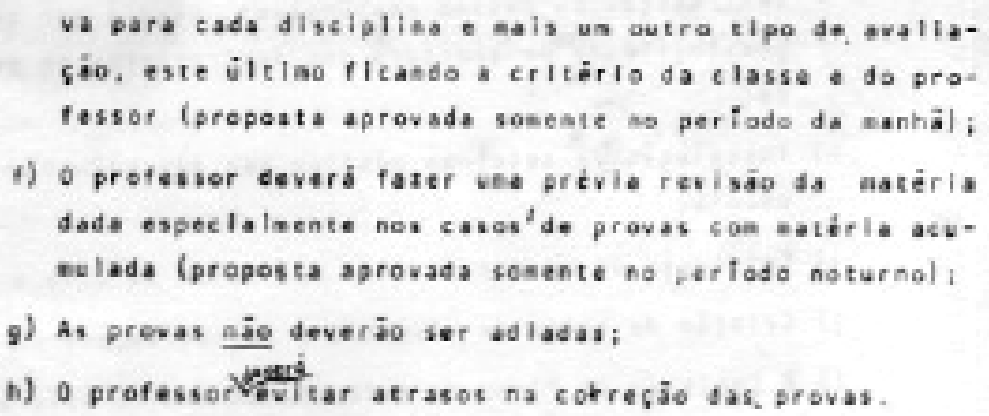

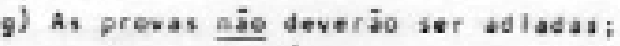

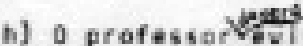

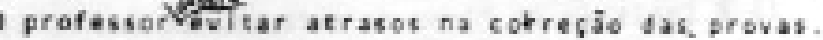

11. 4 - Guatöes rellarionadar 7 racuperagis

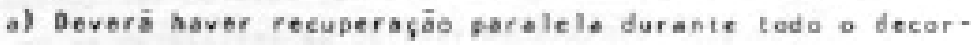
iref do dino Ierino:

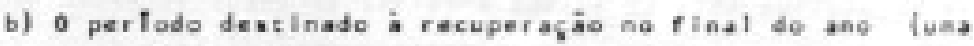
stanal deveri sar proluhade;

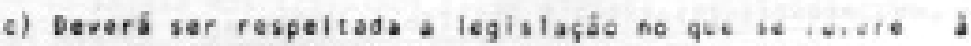

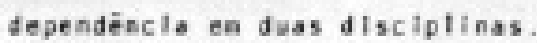

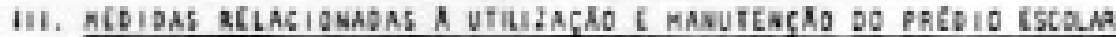

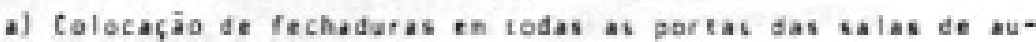

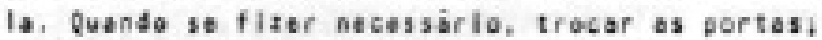

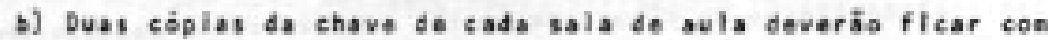

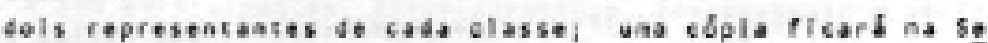

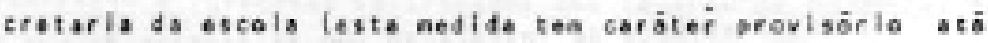
- Insalacis dat calasublentel:

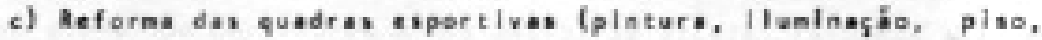
tabelat the I I

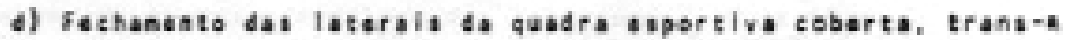

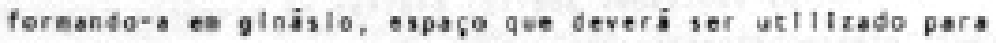

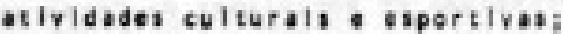

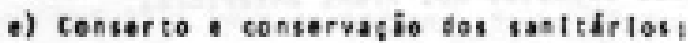

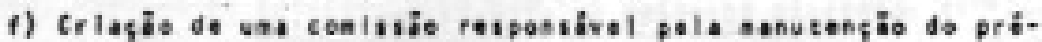

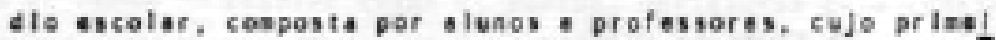

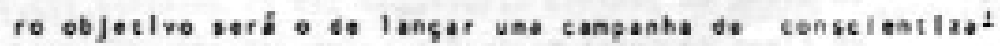
fï da pracervagio to patringonlo pübitas!

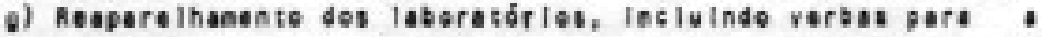




\section{Anexo III - Resoluções do I Congresso - 1981 - página 09}

contrategäe de pessoo responsävel. Deverä ser estudada. possibilidade de abertura dos laboratárlos no pertode ta tar des.

h) Instalegajo de telefone público nas dependencies Internes de excala

1) Colocasgo de cestas de I1xo nas salas de aula e no pitloz

j) Crlagáo de sales de vivêncla e de recreagäo:

1) A Comissäo do Plano de Helhorie do Enaino devera eacarregar ese sa cantults junte alunos, professores a funclonários sobre o intercsse destes en fader refelgôes na escola. In caso de interesse da naiorla, deverão ser conadas as deviAas providănclas no sestido da Inataleçăo de un refaltório con o decorrente oferecinento de atrends escolar.

\section{HEDIDAS RELATIVAS A GUESTAQ OR INTEGRACKO ESCOLACCOMUNIDRDE}

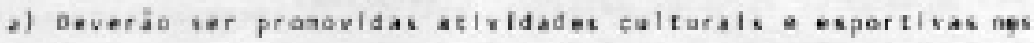
feriodos, filas-ea-semana e perfodos de lerias contando coll - particlpaçio da comusldade;

b) Deveräo ser pronozidos cursos etividades visendo atender o interesis de pali e abes de alunos, a exemple de corte $e$ costura, cullabia, puericultura, platura etc.l:

c) Anpliagabo do nüsero de festas realizadas as escoloi festa do

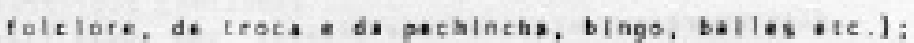

d) mater esforgo de letegregio con as escelas da redendexa.

Aa Conlazea abolxo, claltas ha plenäla final de Cono

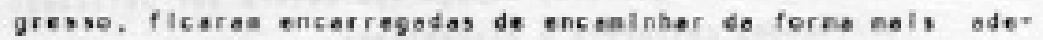
quada as reseluçes expestes nes lisha anterteres.

\section{COHISSAO DO PLAMO DE MELHORIA DO ENSINE}

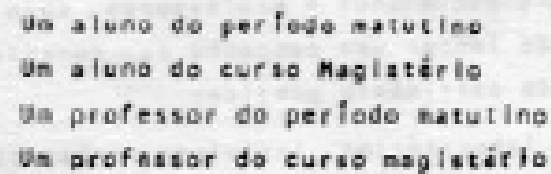

- 9 .
(12) Ifa)

(Anodir)

(Anfela)

(Marlo Leiza) 


\section{Anexo III - Resoluções do I Congresso - 1981 - página 10}

$\begin{array}{ll}\text { Ue oleno do periodo hoturas } & \text { (Josuel) } \\ \text { Un professor do pertodo noturna } & \text { (Eduardo) } \\ \text { Un representante da Aprotsp } & \text { (Cristina) } \\ \text { Un representante do C.C.E. } & \text { (Leonardo) }\end{array}$

2. COAISSAO DE ESTUDO DS AEEIAERTO ESCOLAR

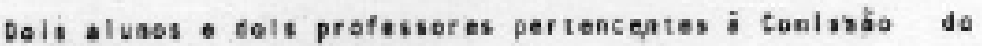
plane de Netherta do Enstare.

3. CEMSELEO CONSULTIUD

- Cealssio Drganizadora do Congresse, composca por sets pro-

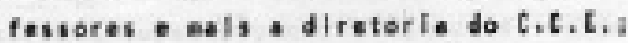

- Repreventances dos salas de cula. 


\section{Anexo III - Resoluções do I Congresso - 1981 - página 11}

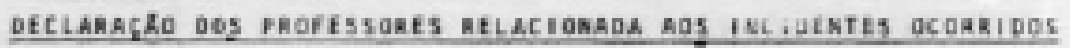

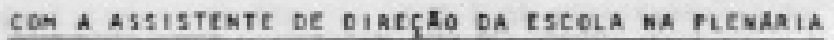

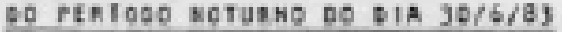

Considerando guet

1. houve erros no encaslahanento na plenarib de onten (30/4/83) sobre a particlpaça da essistente ta dirą̧a que não

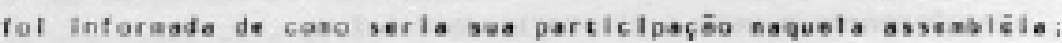

2. näo se deve canfusdir a Alreşöo do perfodo neturno ge la Profa. lacy cen a "diregio" de pertedo dierno de $\$ r$. Darti

3, en relaçāo i direçio do perfodo noturno que se saate-

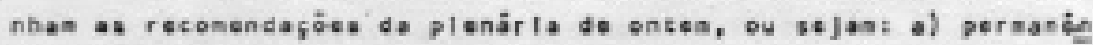
cis coastante as escolb, b) nalor lategregbo entre direģob e aluกอง ;

4. en relegie b direçio so pertodo diurna, apolanss a de liberagbo de Congresso pele afastanto do Sr. Dari, rotada por grande salarla,

nós, Pkeflssokfs, reuntdos, declarames reconhecer. Importincla e a pualidade dos trabaliho desenvelvido aela frofa. laey, ben eono

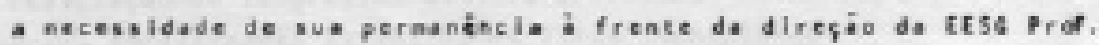
Ayres de Houra o a conclananss a partlelpar seste précesio.

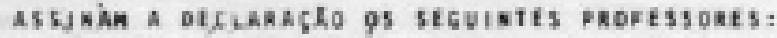

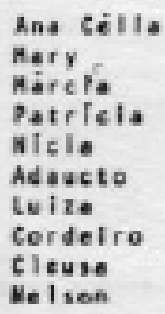

Jeena

Kotona

Cristina

lúcla

Eduarde

Har gare th

funice

Hix lase

Hithe

Yelion

Frapeiseo 


\section{Anexo IV - Proposta de mudança curricular}

Proposta de malanct eurrioular

Egta proprata tem por objetivo tentar reaolver os probleals de con toúdo das diao:plinas minlatradag no 29 zrau. Con esta proposta 11030 e. Iminadio as asguintha disolplinass PTT-rrograma de Infornsção Profisa1o

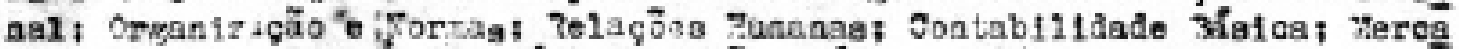

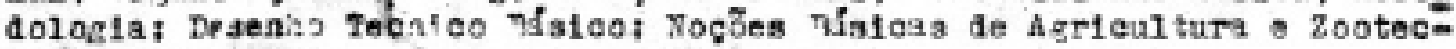
nfa; Sietrioldade.

Quaf;o \& grade curricular para o tagietér10 näo elzboramog pronogta, por a hazaos, pela vua eapeoiflâde e lmportânola, que neosartamos de uma discussäo $\mathrm{mals}$ aprofundads.

\section{D.SCTPIIT: \\ níhero de aules senanats

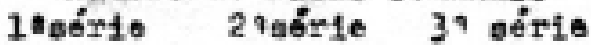

Ifngua, Literatura

If ingus tatrange ira

6

BA.Artigt1ea('ilot, da Arte)

2

4

22

Yato ítiea

PI ies

Q: 1 Intca

isoidona

* rogranas de Saúde

distórta

oeograesa

Ra. Foral a cfofou

Oit,sgo: enol. Iras.

Etuc. Fíroa

htipidader Artigttoag

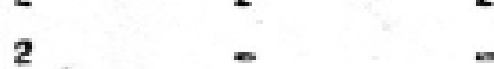

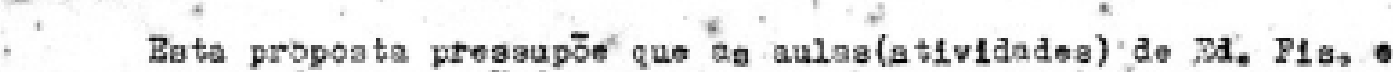
Artes, ben cons a formaçëo(dgrenvolvisento), de hab1lidades deja felto Fovi. to perfodo le aulas, aléa de pressupor un suranto de número de aulsa ad noturno, para 30 aulas semanala, sen̉a 6 aulas diárias de 35 minutoa, todas elas dobradas. A Implantsçäo das dalảa anbiento também deve $v 1 r$

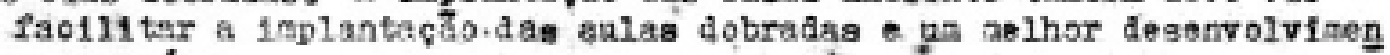
dos contaúd os,

xäo pretendeaos que osts proposts asja soerts obno está, apenaa que ofrva do ponto do partida para, a alsckssp̈o do problena. 


\section{Anexo V - Jornal Folha de São Paulo - 18 de fevereiro de 1984}

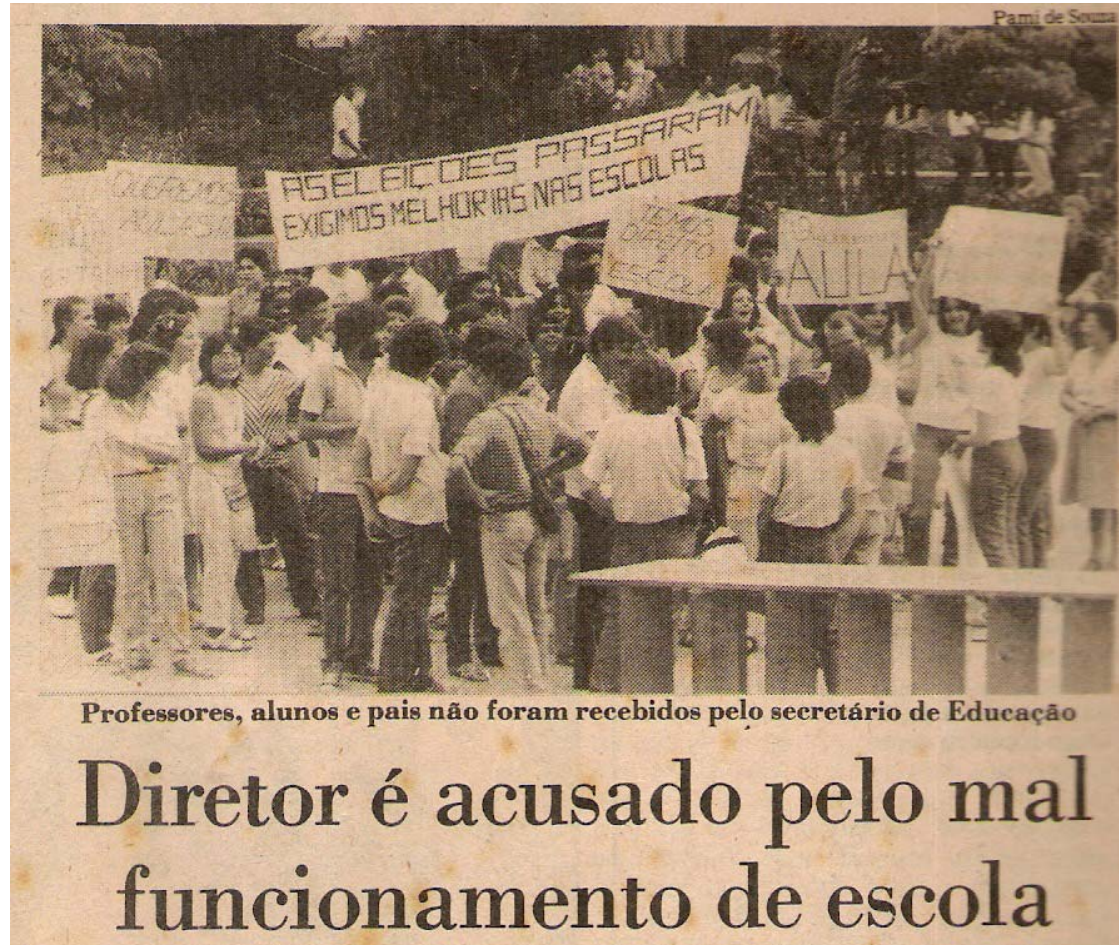

0 inspetor de alunos trabalha quando quer, 0 que facilita a realização de verdadeiros campeonatos de moto-cross nas escadarias e no pátio da escola (uma professora quase foi atropelada essa semana ao sair da aula). Carros de professores e alunos são constantemente arrombados já que não há zelador. Pessoas estranhas entram e saem livremente e fumam maconha acintosamente, além de ameacar as alunas. Há apenas um funcionário para trabalhar na secretaria, o que imperra a expedição de documentos (uma aluna, classificada no vestibular, não pôde matricular-se porque os documentos exigidos pela faculdade não foram entregues dentro do prazo).

De acordo com o depoimento unânime dos 60 membros de uma comissão de professores, alunos, pais e funcionários da Escola Estadual de $2^{\circ}$ Grau Aires de Moura, de Vila Jaguara, na zona Oeste, que ontem procurou o secretário da Educação, Paulo de Tarso Santos, para exigir a demissão do diretor David Batalha de Lima, fatos como os acima citados viraram rotina naquele estabelecimento. Tentativas para mudar esse quadro não faltaram, asseguram eles: "A comunidade escolar chegou até a realizar um congresso em junho de 1983, a fim de avaliar a situação", informou o professor Nélson Frateschi, irmão do deputado estadual Paulo Frateschi, do PT. Na ocasião, o diretor teria sido apontado como responsável pela situação.

Logo depois - prosseguiu o professor Frateschi - encaminhamos um documento à Divisão Regional de Ensino (Drecap 1), contendo um relato de todas as irregularidades. No final, era solicitada a demissão do diretor.

\section{Pelo telefone}

Alheio aos fatos, 0 secretário da Educação negou-se a receber a comissão, alegando compromissos assumidos anteriormente. Mas recebeu a imprensa, e soube das denúncias. Entâo, comunicou-se por telefone com o Departamento de Recursos Humanos (DRHu), órgão da Secretaria, e procurou saber quais medidas poderia tomar para afastar o diretor o mais rápido possível.

Surgiram então duas hipóteses: a diretora da Drecap 1, Magdalena Ussui, procuraria o diretor da escola para sugerir-lhe seu afastamento, ficando ele comissionado na própria Divisão; ou instalar sindicância, ouvindo-se 0 diretor e os membros da comunidade escolar.

Em seguida, o secretário ligou para Magdalena Ússui. Ela contou, então, que 0 documento dos reclamantes (entregue na Drecap 1 em junho) só havia chegado a suas mãos na última quinta-feira e que na próxima segunda feira iria até a escola, como membro da comissão de sindicância, já instaurada, apurar todas as denúncias. (Segundo Paulo de Tarso Santos, dependendo do parecer da Drecap 1, será adotada uma das duas hipóteses levantadas inicialmente).

Ainda ao telefone, a diretora da Drecap 1 informou ao secretário que recentemente havia nomeado 0 professor Hilmo Alves como assistente do diretor, e que tinha esperança de que sua atuação resolva os problemas da escola. As informações dos membros da comissão que visitou ontem a Secretaria, no entanto, não foram favoráveis ao assistente. 


\section{Anexo VI - Jornal Folha de São Paulo - 03 de março de 1984}

\section{Fiscola faz greve de protesto contra punição de professores}

A Escola Estadual de Segundo Grau Aires de Moura, localizada em vila Jaguara, Zona Oeste da Capital, está com suas aulas paralisadas, em virtude de os alunos não aceitarem as atitudes consideradas autoritárias que vêm sendo tomadas pelo diretor do estabelecimento, David Bataglia de Lima.

Os professores informam que a situaçäo chegou a um impasse quando, no início da semana, os estudantes decidiram pintar o muro da escola de amarelo, em virtude da campanha pelas eleições diretas para a Presidência da República. A manifestação dos alunos levou o diretor a recorrer ao $33^{\circ}$ Distrito Policial, onde denunciou três professores como "agitadores", aos quais aplicou a pena de suspensão de 15 dias. Em razão dessa punição, os alunos decidiram entrar em greve.

O diretor é acusado de "preguiçoso" e "relapso" porque ainda nẫo elaborou as listas de classe, não contratou docentes, funcionários ou mesmo montou os horários, o que teria, na visão dos professores, provocado efetivamente a paralisação das atividades da escola. o argumento de que os docentes punidos promoviam reuniões e deixavam de dar aulas foi rebatido por documento, assinado por vários professores, no qual afirmam que todos os encontros promovidos na escola tinham por objetivo a integracão do estabelecimento com a comunidade e que não coincidiam com os horários de aulas. Lembram também que houve nessas reuniões propostas de greve, com a qual não concordaram os professores presentes.

Esses docentes procuraram então diversos órgãos da Secretaria da Educação, onde procuraram a situação existente na escola. Em razão disso, a Delegacia Regional abriu inquérito para apurar responsabilidades.

A Associação dos Professores do Ensino Oficial do Estado de São Paulo Apeoesp - exige a imediata revogação das punições aos professores além de intermediação da Secretaria da Educação para encontrar uma saída para o impasse criado. O prof. David Bataglia de Lima não foi localizado ontem na escola, onde se informou que entrara em período de férias. 


\section{Anexo VII - Ata do Conselho de Escola - página 01}

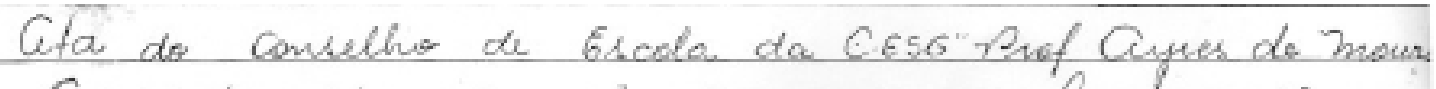
Cor tite dious do mis de movis de hum mil, nou

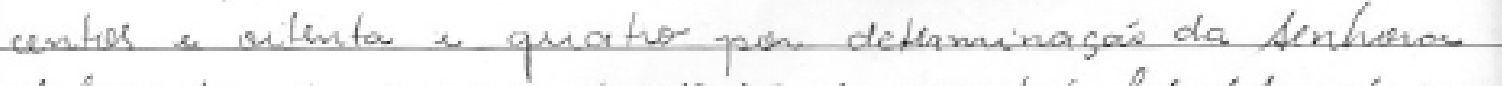
delegada de emime da la bif da capestal, foi delegada a pa

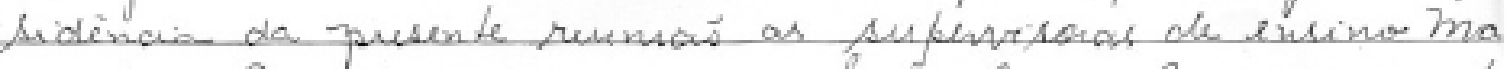

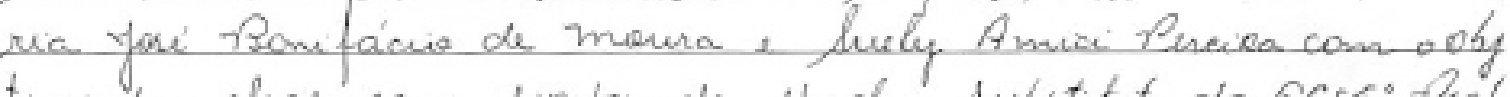

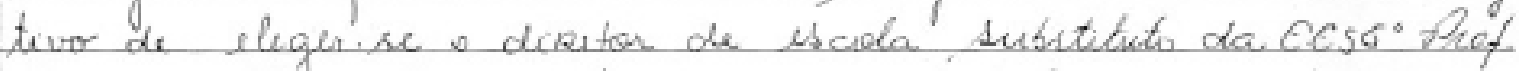

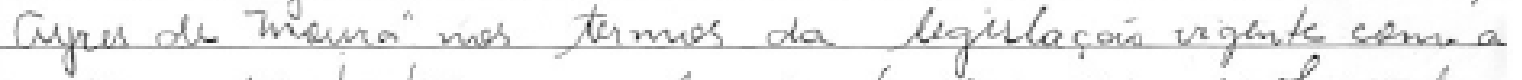

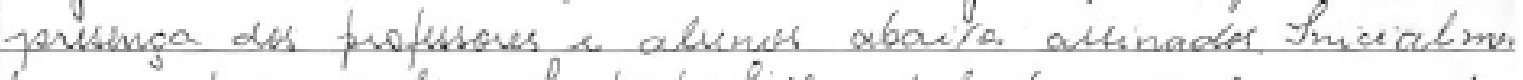

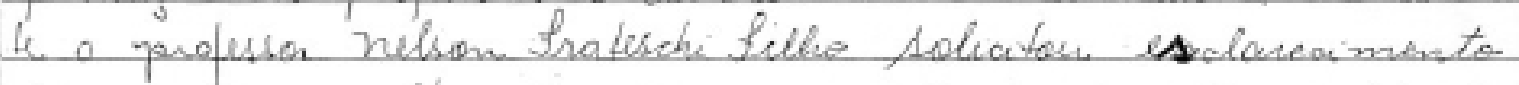

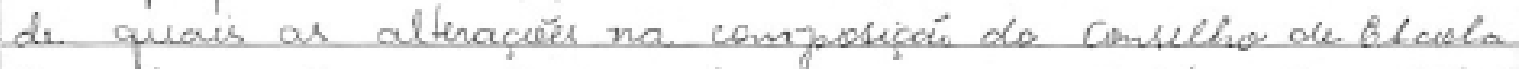

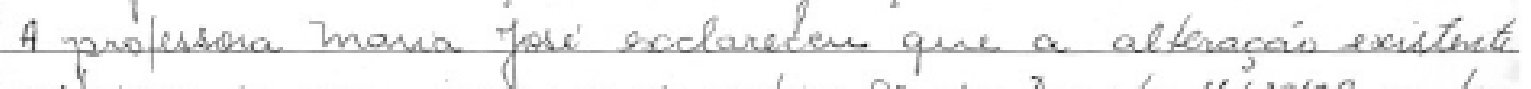

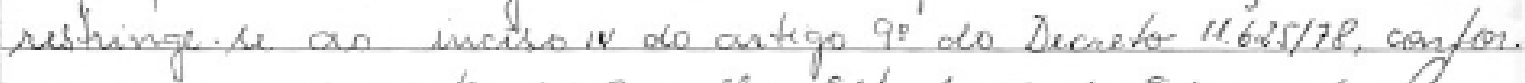

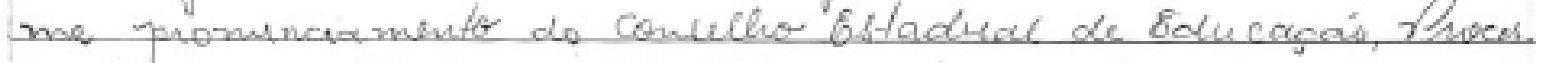

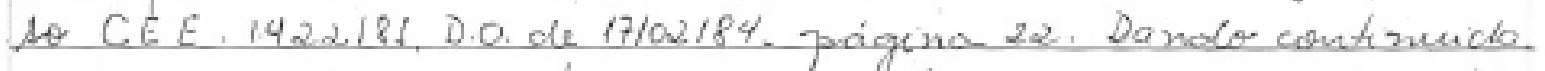

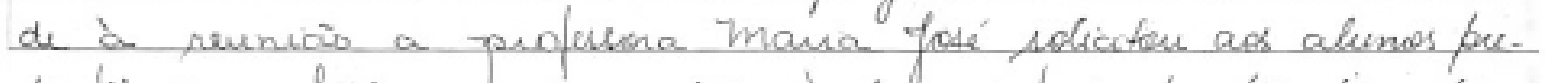
sentes que fossem nomeados os does representantes discintes

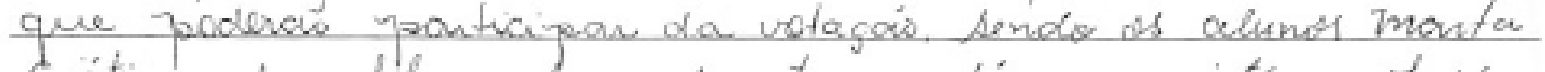

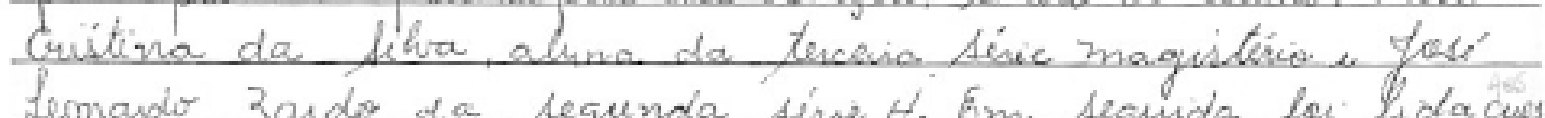

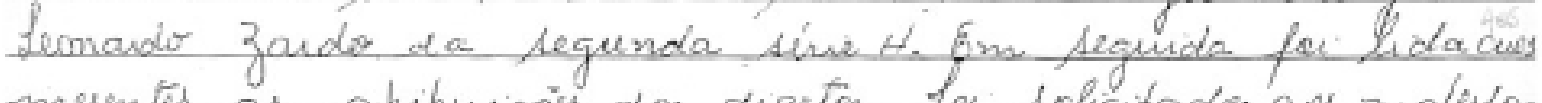

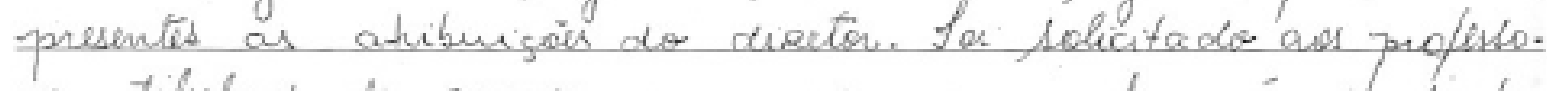

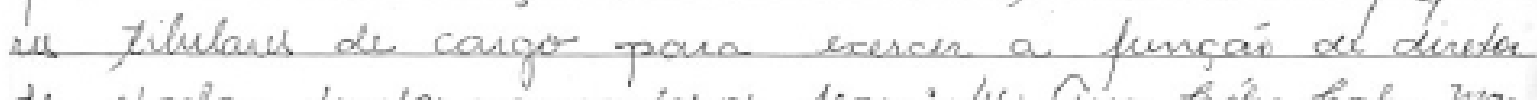

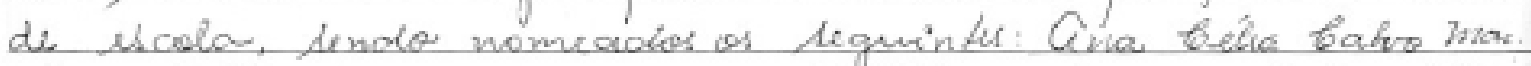

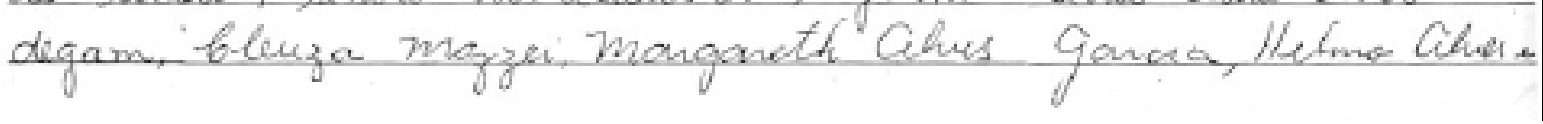




\section{Anexo VII - Ata do Conselho de Escola - página 02}

Waller da libre, dendo indagade um a um de no presuld

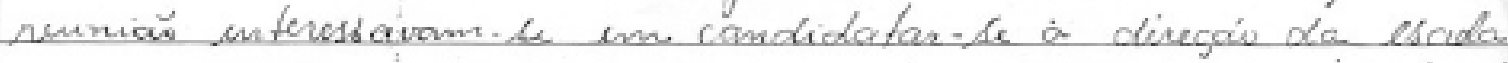

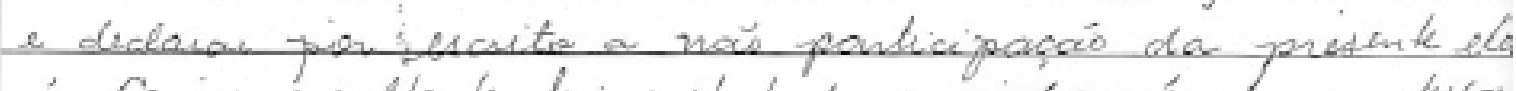
cás. Comer rusuttante for constatado a vidicagás da ytroflssale

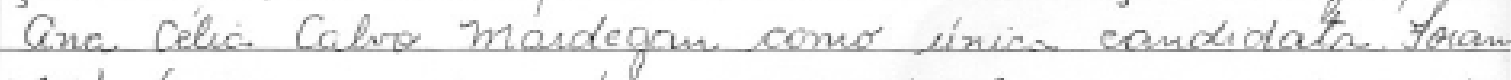

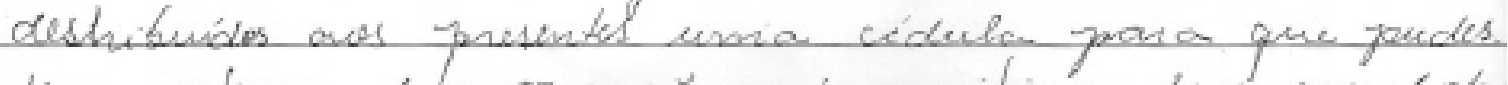

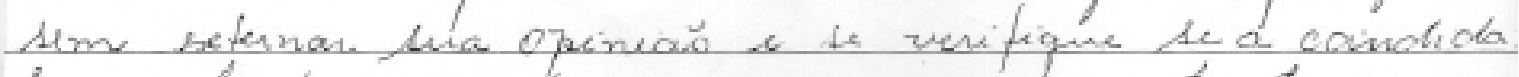

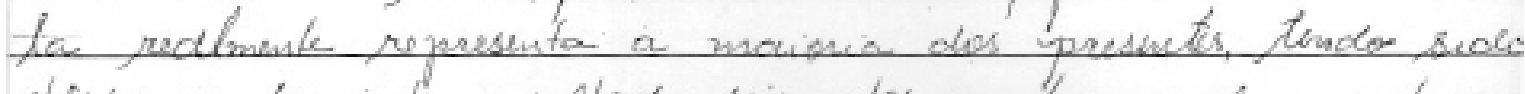

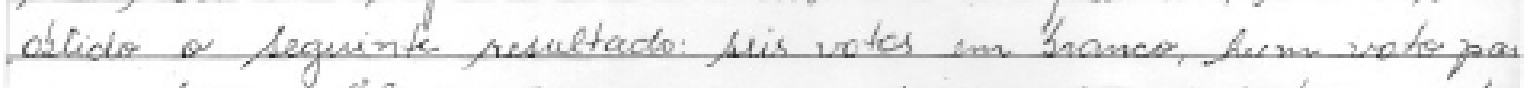

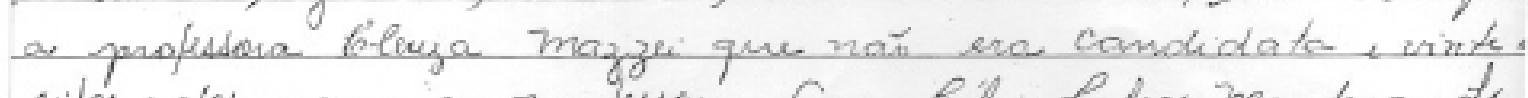

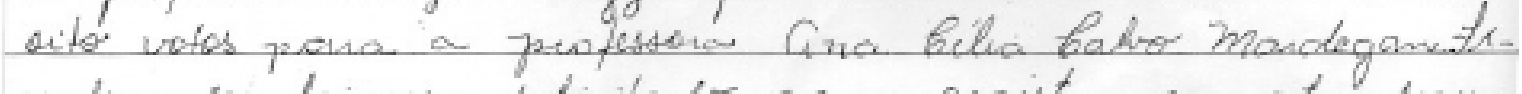
naligando for-mos solicitado para registar ene ata segeino

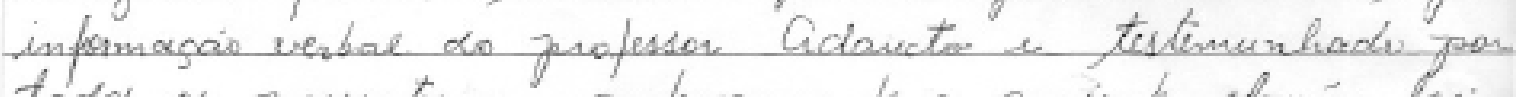

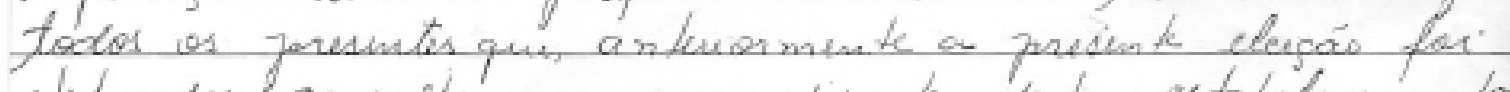

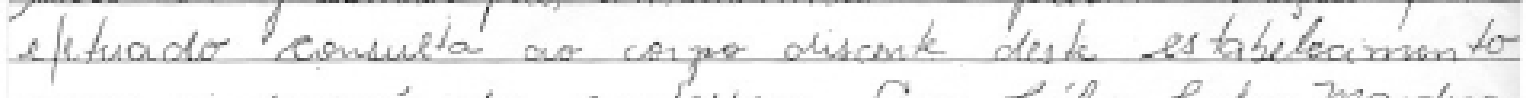

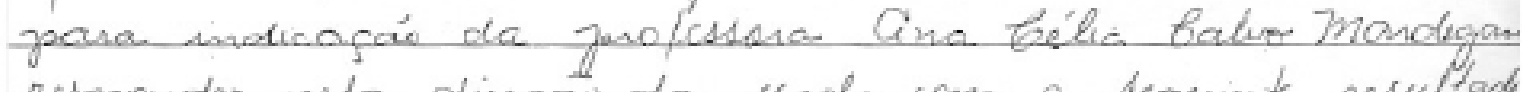
responder peta diregaw do usada com o peguinte resultade

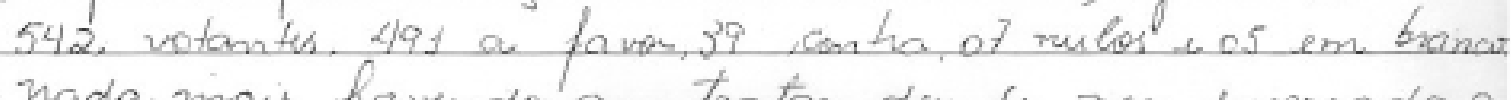

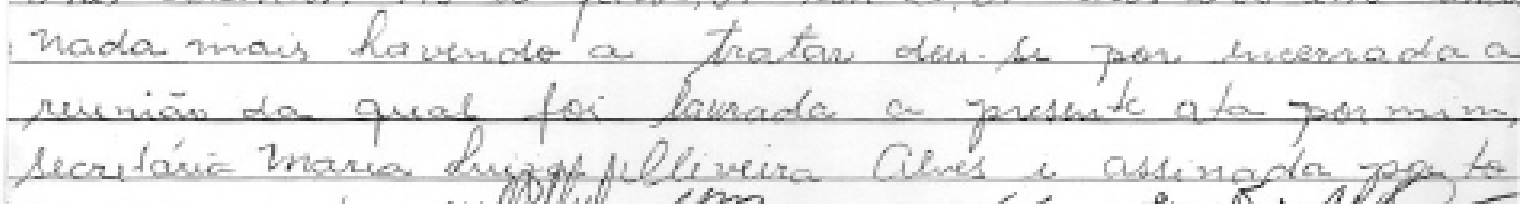

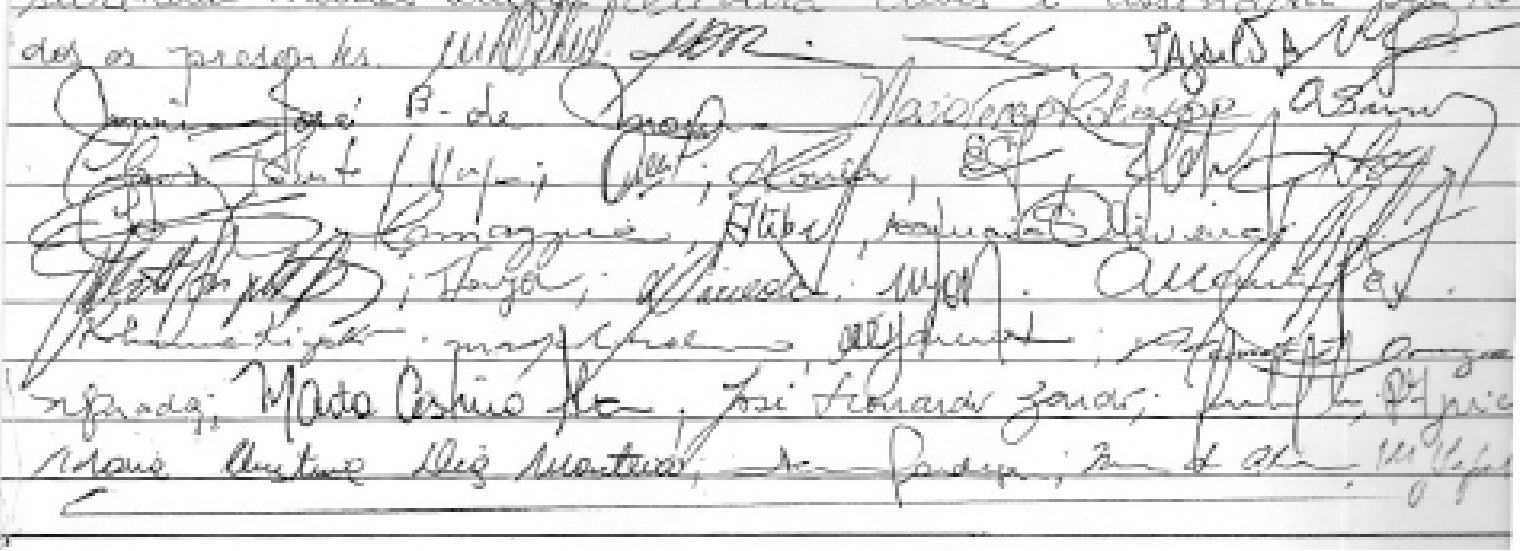


Anexo VIII - Resoluções do V Congresso - 1989 - página 01

\section{$5 \cdot$ CONGRESSO}

E. E. S. G. PROF. AYRES DE MOURA

\section{PROPOSTAS}

APROVADAS

Realizado em Abril/89 


\section{Anexo VIII - Resoluções do V Congresso - 1989 - página 02}

\section{RATIFICAÇĀO DA ESTRUTURA DA ESCOLA}

\subsection{Sala Ambiente}

a) Deverá ser mantida a sala-ambiente;

b) Para facilitar a circulação os dois portões do prédio II deverão permanecer abertos nas trocas de classe pelos alunos;

c) No perfodo de circulação dos alunos (entrada, intervalo e troca de salas), ninguém poderá permanecer sentado nas escadas;

d) Maior respeito ao horário de troca de classe;

e) As salas de aula deverão permanecer fechadas durante o intervalo;

f) $\mathrm{O}$ aluno que não estiver em aula não poderá permanecer nos corredores.

Sugestão: $\mathrm{Na}$ medida do possível os professores e alunos deverão organizar melhor as salas-ambiente e procurar adotá-las de mais recursos.

\subsection{Participação dos Alunos no Conselho de Classe}

a) Os alunos poderão participar dos Conselhos de Classe, nos $10,5,20$, e 30

b) 0 número de representantes por classe será de 5 (cinco) alunos: os 2 representantes e mais 3 observadores escolhidos pela classe, no noturno e 3 representantes, a critério da classe, no diurno;

c) $\mathrm{O}$ aluno que tiver algum problema e quiser participar do Conselho de Classe, só poderá participar se for escolhido pela classe e incluído entre os 5 representantes dos alunos no Conselho;

d) $O$ professor deverá entregar as notas e médias para os alunos e conversar com a classe sobre a avaliação do bimestre antes do Conselho de Classe.

\subsection{Eleição pelos Alunos do Professor Coordenador de Classe}

a) O Professor deverá ser eleito pela classe dentro do seguinte processo:

- Cada aluno deverá votar em até 3 nomes de sua preferência.

- Na ata de eleição deverá constar o número de alunos votantes e a votação de cada professor nessa classe.

- Essa ata deverá ser encaminhada à direção da Escola.

- Cada professor deverá ser coordenador de até 2 (duas) classes.

- Se um professor for eleito em mais de 2 classes, ele ficará como coordenador das duas em que obtiver maior percentual de votação, nas restantes serão empossados os professores que obtiverem a segunda votação.

1.4. Eleição pelo Conselho de Escola, de Diretor e Assistente da Escola

a) O Congresso considera a forma ideal de escolha do diretor da Escola, através de eleição na Escola e que os alunos e professores devem lutar por isso. Também considera que a atual direção, escolhida por esse processo, comprova a eficiência desse processo;

b) Uma vez que a legislação não permite a eleição do Diretor e caso um Diretor concursado assuma o cargo de diretor da Escola, este deverá tomar ciência de nosso trabalho e depois de um certo tempo seu trabalho como diretor deverá ser avaliado pelos alunos e professores;

c) O Assistente de Direção deverá ser eleito pelo Conselho de Escola.

\subsection{Conselho de Representantes de Classe}

a) Deverá ser mantido esse Conselho como órgão deliberativo dos alunos e consultivo em relação as demais instâncias da Escola;

b) Serão feitas reuniões mensais ordinárias, e extraordinárias quando necessárias, com a falta dos representantes abonada;

c) Os Representantes de Classe serão eleitos diretamente pelos alunos, em eleição secreta;

d) O C.R.C. poderá ser convocado pelo C.E., Diretoria da Escola e Diretor do Grêmio;

e) Os alunos deverão ter participação ativa junto ao C.R.C.;

f) A classe poderá substituir seu representante junto ao C.R.C. a qualquer momento;

g) O Grêmio elaborará um calendário das reuniő́es do C.R.C. para que as faltas sejam abonadas.

\subsection{Manutenção do Curso Magistério Noturno}

a) Aprovada a manutenção do Curso Magistério Noturno;

b) Será estudada a possibilidade de ampliar a área de estágio para outras escolas da região que não façam parte da 1 ạ D.E.;

c) Será feita ampla discussão sobre a instalação de cursos técnicos, seus objetivos para que se tenham argumentos que viabilizem sua instalação na Escola; 


\section{Anexo VIII - Resoluções do V Congresso - 1989 - página 03}

d) O Grêmio deflagará campanha para implantação do curso Magistério Noturno em outras escolas da região:

e) Os alunos do curso de Magistério da Escola batalharão para que a opção Magistério / Inciso possa ser feito na 2 a série;

f) Deverá ser desencadeado um processo de discussão sobre o curso do Magistério e CEFAM, uma vez que se considerou que as oportunidades proporcionadas pelos dois cursos não são as mesmas.

Sugestão: Que haja maior assistência aos alunos no estágio por parte do professor coordenador do estágio.

\subsection{Realização Anual do Congresso da Escola}

a) Aprovada a realização do Congresso Anual da Escola, com participação de alunos, professores e funcionários da Escola e que discutirá e deliberará sobre as questões referentes à Escola que a própria comunidade julgar pertinentes;

b) Que seja feita uma semana de Integração no inf́cio do ano na qual se discuta o que é Congresso, que se entregue um folheto com as resoluções do Congresso anterior e que no final dessa semana seja eleita uma Comissão Organizadora de alunos e professores, que marque o Congresso para abril ou maio, como data indicativa para o Conselho de Escola, mesmo se houver paralisação de aulas no período.

\subsection{Manutenção do Conselho de Escola}

a) Aprovada a manutenção do Conselho de Escola

b) Deverá ser feita campanha de esclarecimento a respeito do papel do C.E..

\section{APRIMORAMENTO DAS RELAÇŌES HUMANAS}

\subsection{Relação aluno/aluno}

o Grêmio promoverá atividades para que haja uma maior integração entre os alunos na escola.

Fica com sugestão a organização de comissões responsáveis por essas atividades, além de outras sugestôes, abaixo.

- Deverá haver mais respeito, união e consideração entre os alunos;

- Deverá se buscar uma maior integração do CEFAM com os demais setores da escola;

- Como sugestões de atividades poderão ser realizadas gincanas, debates, 30 Festival Oeste-Rock, atividades culturais, campeonatos, excursões.

\subsection{Relação aluno/funcionário}

a) Diante da constatação que o atendimento na Secretaria fica prejudicado pela falta de funcionários, deverá fazer uma campanha pelo aumento de número de funcionários na Escola;

b) Os funcionários da limpeza deverão ser tratados com respeito. A eles cabe limpar e aos outros procurar manter a escola limpa.

\subsection{Relação aluno/direção}

Constatação: Os alunos estão contentes com a atual direção. Apesar de existirem problemas, ambas as partes tem demonstrado interesse em resolvê-los.

2.4. Relação aluno/profẹssor

a) As relações entre alunos e professores deverão se pautar pelo respeito mútuo, evitando o autoritarismo e tentando criar uma relaçäo de harmonia ser humano/ser humano que supere a distância da sala de aula;

b) O professor deverá abrir o maior espaço possível para a participação do aluno;

c) O aluno deverá reconhecer o papel do professor e assumir suas responsabilidades como aluno, lutando de forma madura pelos seus direitos:

d) Os professores deverão reconhecer a maturidade dos alunos;

e) Deverá se dar muita atenção à realização de atividades extra-classe e de integração;

f) Alunos e professores terão direito a um atraso de 15 minutos. A partir daí poderão entrar, mas ficarão com falta (noturno):

g) Problemas entre alunos e professores deverão ser resolvidos primeiramente entre o professor e a classe. Se necessário será pedida a intermediação do professor coordenador da classe. Só no caso de não resolução da questão ela será levada à direção da escola e em último caso ao C.E. 


\section{Anexo VIII - Resoluções do V Congresso - 1989 - página 04}

\section{QUESTÕES PEDAGOGICAS}

\subsection{Avaliação}

a) Deverá haver por bimestre no mínimo duas avaliações, sendo que uma deverá ser escrita e outra(s) a combinar entre professor $e$ aluno;

b) Não deverão ser marcadas duas provas no mesmo dia, incluindo chamada oral, entrega de trabalho, seminário, prova com consulta. No caso de não ser possível, será feito um acordo entre o professor e a classe;

c) Não poderão ser marcadas provas na 1ạ e 5 ạ aulas, a não ser que o professor só tenha este horário com determinadas classes. Deve-se lembrar que o bom senso prevalece, de ambas as partes;

d) As provas deverão ser elaboradas pelo professor e feitas pelos alunos dentro do limite de uma ou duas aulas;

e) As provas bimestrais deverão ser marcadas pelo professor com 15 dias de antecedência, caso não seja possível deverá haver acordo entre o professor e a classe;

f) O professor deverá apresentar critérios claros e objetivos sobre a avaliação que está sendo feita;

g) Como a prova é considerada uma forma muito limitada de avaliação, dever-se-á na medida do possível, tentar criar formas mais abrangentes de avaliação, a serem combinadas entre o professor $\mathrm{e}$ a classe;

h) Quando houver notas numér icas, sua conversão em letras deverá ficar clara para o aluno;

i) O professor deverá comentar as avaliações quando entregá-las para a classe;

j) O resultado do bimestre deverá ser apresentado ao aluno antes do Conselho de Classe;

1) Quando o professor continuamente não preparar as médias até a data do Conselho de Escola, o fato deverá ser levado ao Conselho de Escola, para estudar uma possível advertência;

m) Casos excepcionais ficarão a critério de acordo entre classe e professor;

- Critérios para atrasos em dia de avaliação.

- Falta do aluno e professor em dia de prova.

n) O Congresso deflagará um processo para avaliação do professor.

\subsection{Planejamento}

a) O planejamento anual deverá ser seguido mesmo havendo mudança de professor;

b) $O$ planejamento anual deverá ser afixado durante o ano letivo em sala de aula com seus objetivos e conteúdos:

c) O planejamento deverá ser desenvolvido de acordo com o ritmo, interesse e formação do aluno:

d) Os alunos deverão participar do planejamento no começo do ano (manhã);

e) Que continue sendo feita a recuperação semestral;

f) Deverá se lutar pela criação do professor coordenador de área, junto à Secretaria da Educação.

\section{MELHORIA DAS CONDIÇŌES MATERIAIS DA ESCOLA}

\subsection{Biblioteca}

a) O C.E. deverá organizar campanhas para melhorar o acervo da biblioteca e fazer assinaturas de jornais e revistas;

b) O C.E. poderá estabelecer o pagamento de uma taxa pelos alunos para cobrir as despesas com aumento do acervo, assinatura de jornais e revistas e salários dos funcionários da biblioteca.

Posteriormente o C.E. deverá prestar contas do dinheiro arrecadado;

c) $\mathrm{O}$ uso da biblioteca será exclusivo para estudo e pesquisa sendo vedado o seu uso para outros fins;

d) Os livros não poderão ser retirados sem a autorização da biblioteca e sem carteirinha. Em caso de atraso deverá ser cobrada uma multa cujo valor será estabelecido pelo C.E..

\subsection{Segurança}

a) A segurança da escola é responsabilidade de todos os alunos (noturno);

b) Não será contratado porteiro para segurança (noturno);

c) Deverá contratar um porteiro para a escola, que conheça os alunos. Não será feita nenhuma forma de arrecadação de dinheiro para isso, pois a comunidade considera o pagamento do porteiro um dever do Estado (manhã): 


\section{Anexo VIII - Resoluções do V Congresso - 1989 - página 05}

d) Deverá fazer uma campanha junto à D.E. visando o cumprimento dessa obrigação (manhã):

e) Procurar divulgar, pela imprensa, sempre que houver oportunidade, as más condições da escola;

f) Procurar divulgar pela Revista de Educação o que há de bom na Ayres de Moura:

g) Pedir que a ronda escolar passe em horários alternados, nos horários de entrada e saída;

h) Procurar conseguir junto a C.E.T. a colocação de uma lombada em frente à escola.

\subsection{Limpeza}

a) A limpeza da escola será responsabilidade de todos na escola e cabe a todos mantê-la;

b) Deverá procurar conseguir outro mural de recados:

c) O Grêmio organizará os alunos que trabalham com graffitti, determinando os espaços a serem trabalhados e desenvolvendo campanha contra pixaç̃̃es;

d) Abertura do banheiro feminino do prédio 2, caso seu uso seja viável;

e) Deverá ser feito mutirão para a limpeza da escola, do qual participarão todos os mem. bros da comunidade que estiverem interessados.

\subsection{Laboratórios}

a) Deverá efetivar o uso dos laboratórios e fazer uma campanha para arrecadar material;

b) Eleição de uma comissão para pressionar a Delegacia de Ensino para envio do material para o seu funcionamento;

c) Deverá ser feito um mutirão para limpeza dos laboratórios.

\subsection{Vídeo}

a) O vídeo foi uma conquista importante da escola e é um direito de todos, portanto todos são responsáveis por ele;

b) Deverá ser definido um calendário para uso da sala de vídeo:

c) Uso mais frequente do vídeo pelos professores;

d) Uso do vídeo pelos alunos através do Grêmio. O C.E. definirá as regras do uso.

\section{OUTRAS PROPOSTAS}

\subsection{Motos dentro da Escola}

Deverá ser feito um cadastro das motos dos alunos, professores e funcionários que usam o estacionamento do pátio. Pessoas que não são da escola não poderão entrar na escola com motos.

\subsection{Cantina}

Aumentar o número de funcionários em hora de grande movimento.

\subsection{Grêmio}

a) Deverá ser criada associação dos ex-alunos junto ao Grêmio;

b) Deverá ser criado um Jornal interno:

c) Deverá ser instalado som ambiente no pátio, na hora do intervalo.

\subsection{Salão de Reuniões}

a) O salão deverá ser usado exclusivamente para sala de estudo, de reuniões e projeção de "slides";

b) O laboratório de ciências deverá ser transformado em refeitório;

c) Reativação da sala do grêmio e, a título de experiência, do vestiário;

d) A mesa de pingue-pongue deverá ficar na sala do Grếmio ou no pátio, sendo guardada no banheiro. As pessoas que a tirarem de lá deverâo deixar seus nomes se responsabilizando por trazê-la de volta.

\subsection{Vestiários}

A escola, depois da instalação do CEFAM, passa a ter necessidades diferentes, que não devern ser vistas como empecilhos pelos demais setores da escola, mas como conquistas a serem mantidas. Os vestiários são uma delas. Deverá tentar obter os chuveiros para os vestiários junto à $D$.E.. 


\section{Anexo IX - Comunicado sobre a implantação da sala-ambiente - página 01}

EESG."PROF.MINUEL CIRIDINOO BUARUE"

RUA CERRO CORA, 770- V.Ipojuca

A titulo de Orientação do Funcionamento de "Salas-Ambiente ' e numa tentativa de:

a) Evitar ao aluno a monotonia da permanência por 5 ou 6 horas numa mesma sala.

b) Propiciar ao professor, oportunidade de equipar sua sala como meIhor ine parecer.

c) Melhor conforto ao professor, que poderá ter em sua sala todo seu material didático, evitando assim o incómodo transporte de sala para sa$1 a$.

d) Maior conservação de limpeza das salas de aula.

e) Melhorar a manutenção do prédio escolar, das salas de aulas, móveis escolares, etc.

Damos cominecimento aos colegas das normas e providências que nortea ram a implantaçăo do sistema de "salas-ambiente" adotado nesta escola. AOS PROFESSORES

I- Cada professor terá sua sala de aula com a respectiva chave.

2- professor abrirá sua sala pouco antes do inicio de suas aulas, devendo nela permanecer até o final de seu periodo.

3- Em hipótese alguma o professor deve deixar a sala aberta, fechando-a toda a vez que dela se ausentar.

4- Durante o intervalo, o profeșsor poderá ir à sala dos professozes para seu lanche e bate-papo, não se esquecendo contudo de fechar sua sal:

5- 0 professor poderá ter um armário em sua sala de aula para guardar seu. tmaterial.

6- Havera sempre dojs sinais com dois minutos de intervalo entre um e outro: o primeiro e para terminar a aula e o segundo para o início da au Ia seguintie. (curtounético)

7- I muito impcotante que o professor esteja em sala de aula já por ocasj. ao do primeiro sinal.

8- Os alunos teräo dois minutos para deixar uma sala e entrar na outra.

9- Solicitamos ao professor:

a) terminar a aula imediatamente após o primęiro sinal.

b) não permitir que o aluno entre em sala após o segundo sinal, a fim de que ele se conscientize o mais rapidemente possivel do funciona mento do sistema.

c) evitar deixar o aluno permanecer só na sala, ocasião em que ocorrem as "depredações".

10- Os professores que se utilizam da uma mesma sala de aula em períodos ou dias diferentes, poderão estabelecer entre si, critérios para conservação dessa sala.

11- Cada professor poderá dispor de uma hora/aula semanal para limpeza de sua sala. Esta poderá ser feita pelos alunos (em sistema de rodizio)

w com a supervisão do professor, ou este poderá soliçitar à servente er. os alunos numa atividade qualquer a seu critério.

12- O professor poderă colocar cartazes, mapas ou outro material em sua a. la. Solicitamos porèm, não colocar pregos nas paredes. Estes poderä́ s. colocados na moldura de madeira da lousa lateral.

Observação: Em escolas maiores deverá haver: uma escada para subida e out, so para descida. Solicitamos aos professores, não so observarem tamue. esta norma, como fazerem com que os alunos a respeitem. 


\title{
Anexo IX - Comunicado sobre a implantação da sala-ambiente - página 02
}

\author{
AOS ALUNOS
}

Neste ano você irá notar algumas mudançaș na sua escola, mudanças essas que esperamos iräo tornar sua permanência nela mais agra davel se menos monótona. Observe pois que:

1- Cada aula será dada numa sala diferente, numerada.

2- Observe no horário o no da sala na qual cada matéria será dada.

3- Cono vocế já percebeu, haverá intenso trárego pelos corredores e escadas após o término de cada aula. Para evitar o congestionamento, observe a mão e contra-mão tanto nos corredores como tambem

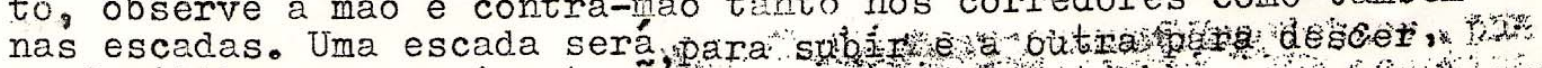
ra facilitar sua movimentaçâja

4- Haverá sempre dois sinais com dols minutos de intervalo entre um e outro. O primeiro é para terminar a aula. Saia imediatamente e dirija-se para a sala em que será dada a aula seguinte, sem correr, caminhando normalmente e sempre observando sua mäo de direçäo.Quã do der o segundo sinal vocé já deve estar dentro da sala de aula. seminte. Portanto, voce tem dois minutos para sair de uma sala e Ei. : a outra.

5- 0 ssor impedirá sua entrada após o segundo sinal.

6- Sye vermanência fora da sala de aula podera significar uma advervoja em sua caderneta. Três advertências poderäo causar-lhe uma rovensäo. Gutdado.

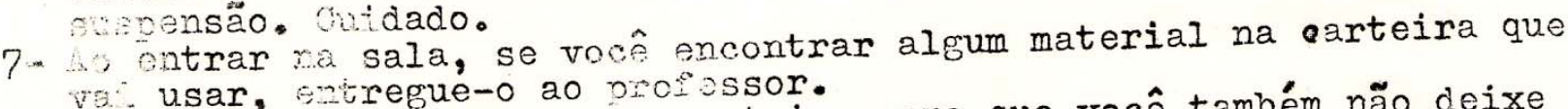

8- Le deixar a sala examine a carteira para que você também não deixe la seu material.

9-- Verifique também se, por descuido, não deixou cair no chão papel ov qualquer outro objeto sem uso. No canto da sala há uma lata de lixo

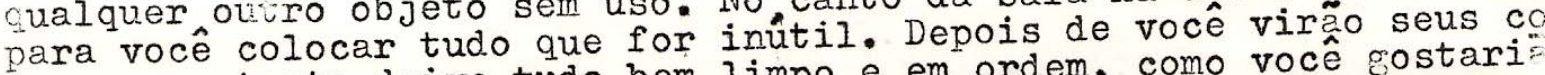
legas, portanto deixe tudo bem limpo e em ordem, como voce gostari: de encontrar. de encontrar.
10- Voc se a o grande colaborador do professor e da direção da escola
na manut gnă da limpeza. No pátio também há latas de Iixo para você colocar todo material inútil. Se um seu colega desatento jogar lixo no chão, peça-lhe que o coloque na lata de lixo. Desse modo você também estará colaborando com ele na formação de bons hábitos.

\section{AOS INSEETORES DE AIUNOS}

I- Pazer com que os alunos observem a mäo e contra-mão nos corredores.

2- Observar para que os alunos usem as escadas corretamente, isto e, uma para subir e outra para descer.

3- Levar todo aluno que esteja fora da sala de aula cós o segundo sinal, até a direção ou pessoa encarregada, para anotar advertência na caderneta.

4- Verificar quantas advertências tem o aluno. Após a terceira,avisar para que ele seja suspenso.

5- Verificar, de vez em quand se não há aluno escondido na toalete.

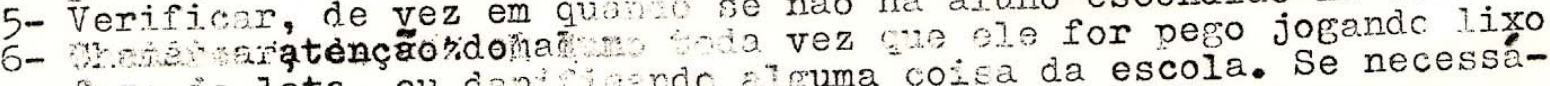
fopa da lata, ou den co avisar a direçäo sob.: o incidente.

\section{AS SEEVENTES}

1- Manter limpo os corredores, as toaletes dos alunos, sala dos professores, toalete dos professores, pátio, etc, varrendo-os diaria mente.

2- A servente fará faxine, nas salas de aula, seguindo horário a ser feito pela direção. 


\section{Anexo IX - Comunicado sobre a implantação da sala-ambiente - página 03}

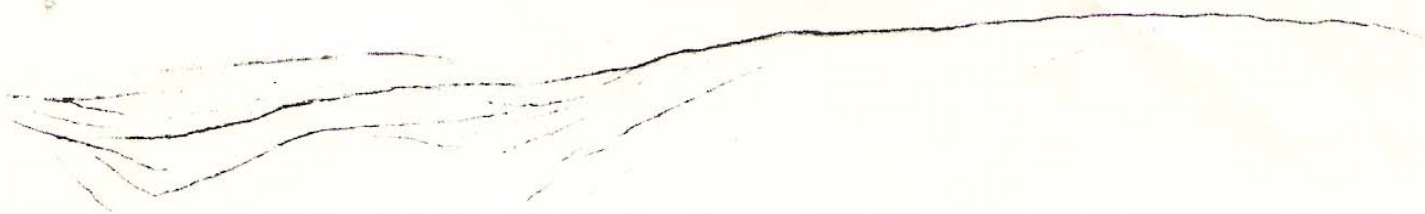

Providências

1- fechaduras e cópias de chaves.

2- numerar as salas

3- latas de lixo para cada sala

4- latas de lixo para pátio

5- bancos para pátio

6- setas de mão e contra-mão nos corredores

7- mão e contra-mäo nas escadas

8- Instmuir serventes sobre a limpeza de sala, quando solicitada pelos propecores

9- Insturir inspetor de aluno sobre a permanência do estudante fora da sala de aula após o 20 sinal. Encaminhá-10 à diretora (ou pessoa encartregauala) pra advertência em caderneta. Após a 2 advertência, suspensão ( 1 dia, depois 2, 3, etc.)

10- Mineografar as instruçöes aos alunos para que cada um receba uma cón pia

11- Solicitar ainda ao professor que no 10 dia de aula, leia em classe sas instruçöes, esclarecendo as dúvidas que surjam.

12- Distribuir as chaves aos professores.

13- Colocar bancos no pátio

14- Fapeleta (para controle de frequência nas várias aulas do dia). 
Anexo X - Textos de Sensibilização - Preparação do I Congresso

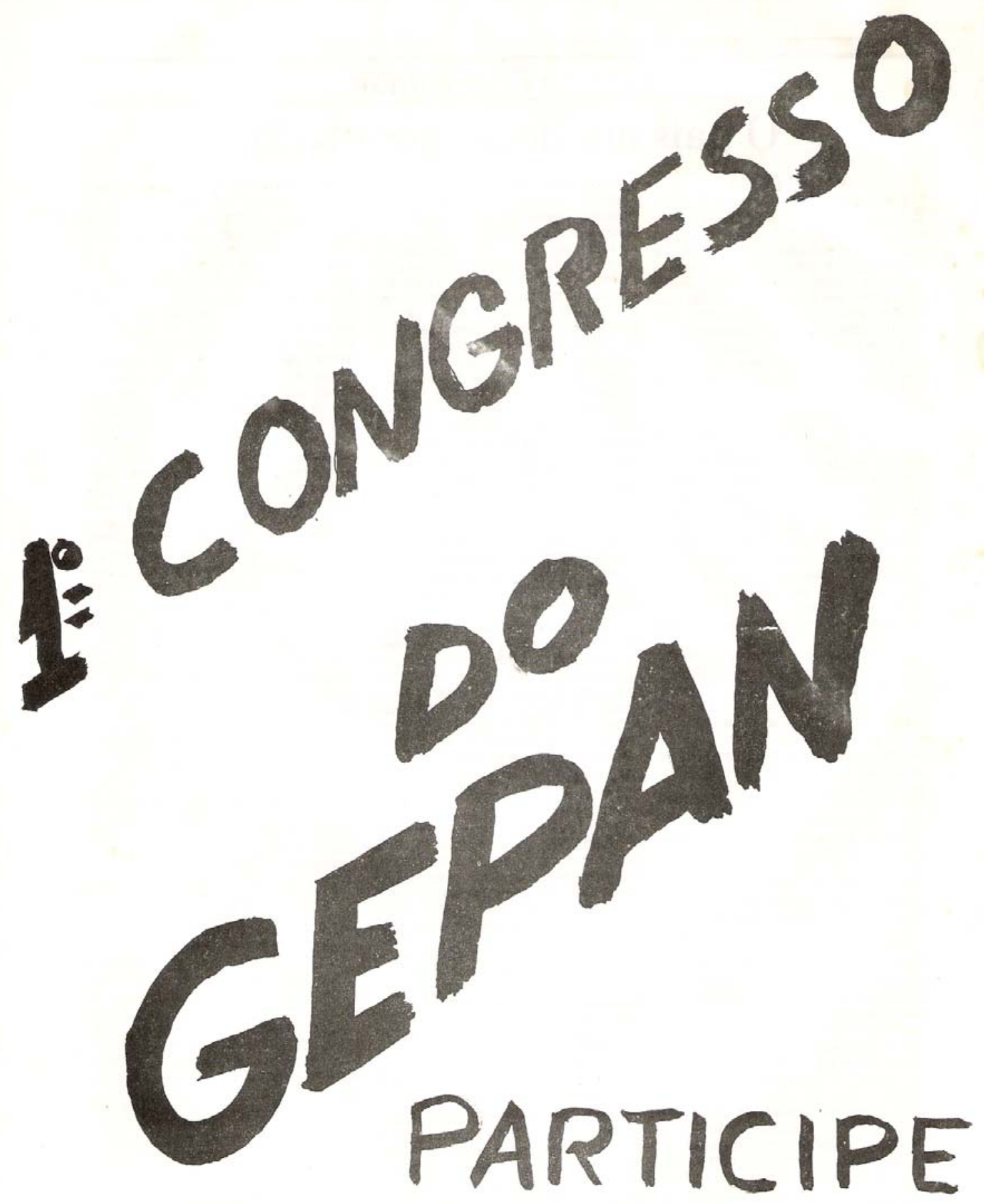




\title{
Anexo X - Textos de Sensibilização - Preparação do I Congresso
}

\author{
14 ... EDUCAÇÃO - Sábado, 4 de junho de 1983 FOLHA DE S.PAULO
}

\section{Ciência e Sociedade}

\section{O país dos dedos gordos (2)}

\section{RUBEM ALVES}

Em pais de terremotos a soluçâo definitiva para 0 perigo dos desa bamentos è acabar com os terre motos. Mas enquanto não se descobre a maneira de tranquilizar a terra o jeito é ir construindo casas de bambu e de papel para que, quando tudo despencar em cima dos que estão dormindo, ninguem fique machucado. que vou dizer sobre a educacåo não porá fim aos terremotos mas pode contribuir para diminuir o número de mortos e feridos.

A tese é simples: os exames ves tibulares se encontram sentre os maiores vilōes da educação brasileira. Seu poder de aterrorizar e intimidar e maior que todas as nossas filosofias e portarias, empacotadas. Se conseguissemos matá-los e en terrá-los. os estudantes voltariam sorrir, dormiriam melhor e aprenderiam mais. Se isso for impossivel. pelo menos castrar e domesticar a fera, para que ela possa ser cavalgada sem perigo... Vou tentar ex plicar esta afirmação aparentemente estapafúrdia

1) Primeiro é a mentira do nome. Dizem que é um exame vestibular. Vem de vestibulo. que è lugar de entrada. Entrada. claro, para a universidade. Porta que se abre para a frerte. E ai. enganados pelo nome, năo percebemos aquilo que eles fecham para trás. Apresentam-se como leōesde-chácara, que só lidam com os adultos, mas não contam para ninguém que. às escondidas, aterrorizam as crianças pequenas. Os vestibulare visitam as fantasias dos pais. rondam os jardins-de-infância, anunciam-se nos anos de primeiro grau e, já no segundo grau, tomam conta da alma e do corpo dos meninos. Todo mundo já está aleijado...

Tudo comeca com os pais. "- Meu filho, que è que vocẽ vai ser quando crescẹr?" O garotinho ainda está brincaando de carrinho de bombeiro $\mathrm{e}$ eles já comecam a perder o sono, pensando se o filho vai ser capaz de passar o vestibular e se eles serão capazes de pagar as mensalidades dos cursinhos. E é porque a angústia tomou conta da sua alma que se afligem quando notam que as escolas não apertam o suficiente. nāo desenvolvem o espirito individualista de competicão e de deixar o outro para trás, e gastam o tempo com atividades supérfluas. Superfluas são as atividades que não se acumulam como um capital que virá a dar ao estudante uma vantagem sobre os outros, na hora do "vamos ver"

Todos concordam: é necessário que a escola dê uma boa base aos seu alunos. Mas acho que ninguem pensa em boa base em termos de prazer, alegria, espirito comunitário, sentimentos generosos e humanistas, sensibilidade artistica, Estas são coisas boas para a vida. Mas não é isto que as pessoas têm em mente ao se referirem à tal de boa base. 0 que elas pens a no tipo de conhecimento que pensam e no tipo de conhecimento que vai ajudar os estudantes a pôr as os vestibulinhos e simulados vão-se tornando práticas comuns, para que o aluno tome consciência daquilo que 0 aguarda. Os professores que fazem e vendem livros didáticos, sabedores disto. tratam de colocar intre os problemas a serem resolvidos alguns que incluam informaç̄es do seguinte tipo: Ita, 1979; Fuvest, 1981. As escolas que os adotam serāo consideradas responsáveis (dão boa ba c para o vestibular, verdadeiros pre-cursinhos...), os pais não chorarão o di nheiro e dormirăo seguros de estarem fazendo o melhor para os seus filhos, e os moços pensarão que estão andando no bom caminho.

Os exames vestibulares, assim. não devem ser pensados como instrumentos adequados ou näo para entrada na universidade. mas antes como instrumento de terror que determina os rumos da educação com muito mais poder que todas as nossas leís. Será inútil que os filosofos e educadore adotem as propostas mais generosas para o ensino. Tudo se dissolve diante deste fato: há um exame que é feito desta e desta maneira.

2) Concluimos, entāo, que quem está determinando os rumos da edu caçāo brasileira é o grupo de pessoas que tem o poder de dizer como é que vestibular val ser. Só existe uma população que está livre deste errorismo: aquela que sabe que nunca terá condiçōes de chegar até universidade. Com esta gente pobre. então, se poderia pensar num processo educativo como se o vestibular nâo existisse, pois que, para ela, ele não existe de fato. Os outros, que pretendem o saber universitário, nảo têm aternativa têm de se colocar de quatro: educar-se como as empresa quatro: educar-se comor as empresas que devam ser educados.

Isto mesmo: empresas fazedoras de vestibular. Pergunto: quais são os criterios que determinam a feitur dos tais exames? Serảo critérios educativos, por acaso? Claro que năo. Sāo criterios acaso? Claro que náo. ducão em massa. As questōes devem ser feitas de tal maneira que $0 \mathrm{com}$ putador não se confunda. Escolhas obetivas (?). havendo apenas uma resposta certa. Para quê? Para que os dados sejam processados de maneira uniforme (leia-se maquinalmente) rapidamente (leia-se economicamente). E depois reclamamos que os moços nảo sabem escrever. Para que saber escrever se este ato é superluo? Saber escrever tem a ver com uma atitude da pessoa que acredita ser capaz de criar colsas novas. Mas e sto que 0 vestibular nega. As resposas certas já estão prontas, competin do ao aluno simplesmente identifica desim deformado a vida nteira nāo apenas nảo sabe escrever como tambem nảo sabe conversar. E ainda mais: desaprendeu o que sig nifica fazer ciencia. Uma professora minha amiga me dizia que os piore alunos no seu campo do saber eram ustamente aqueles que tiravam os primeiros lugares num destes curpinhos gue trombetelam suas virtude le alunos nảo podiam suportar que cientista iva frequentemente diante ae altern: tivas incertas e de opç̋es nào testa"'s. Sua pergunta inevitável é sempre a mesma: "- Mas, professora, qualé a resposta certa mesmo? Ou seja: quando aparecer a pergunta. qual é c cin-iradinho onde devo pôr "X"? Reduzidos a condicoes por inhos na caix onde só há comportinhos na calxu onde so há comportamentos certos e errados: ou a comida ou o choyue, ou a aprovaçăo ou a reprovação.

3) Os cursinhos cantam glórias pōem os ret-ratinhos (isso mesmo. ret-ratinhos.) dos seus aprovados na TV. "- Conseguimos abrir as portas..." Os pais abrem champanhe e se congratulam. Os moços raspam a cabeca e pintam a cara, alegres.. Tudo termina com uma triunfal celebracăo. Sugiro, ao contrário, que celebracáo. Sugiro. ao contrário. que ce faca uma anallse dos aleijos e das deformaçes. Que fol que se perdeu? A educaçăo que năo houve. Aqueles enormes dedos gordos, inúteis.. conhecimento idiota que a memória. sábia, se encarregará de vomitar o mais depressa possivel. Dentro em breve nada mais restará Apenas as cicatrizes. A ansiedade. Os oil cicatrizes. A ansiedade. Os olhares tristes e acusatorios dos pais. O di terrivel sentimento de derrota. Como se a vida deixasse de fazer sentido. pois todos os rituais preparatórios diziam que entrar na universidade era a única coisa que importava. E. eles contam as cabecas que ficaram. Nada dizem daquelas que rolaram peio chäo.

E assim que penso no vestibular: não pelas rumorosas e magras celebracōes que acompanham os sobreviventes, mas pelas cicatrizes que ficam em todos os demais. Qualquer coisa que assim deforme a nossa juventude nảo merece continuar. Está reprovado peia vida. 


\section{Anexo X - Textos de Sensibilização - Preparação do I Congresso}

\section{CONGRESSO DA EEPAM}

EESG PROF. AYRES DE MOURA

Hā necessidade da formação de uma Comissão, cujos integrantes estejam dispostos a trabalhar num só sentido; melhoria do Ensino. Esta Comissão teria a responsabilidade de defender os inte resses do aluno, professor e do Ensino.

Caso seja preciso punir alguém, seja aluno ou professor, o faria com dignidade e não com demagogia.

Que seja decretado o fim do autoritarismo por parte de alguns professores. Acabar com esse negōcio de: "Eu sei mais, tenho diplomas, cursos, etc.", e sim fazer uma junção aluno-professor, para juntos discutirem uma possível reforma no Ensino. A participa ção de ambos seria indispensāvel e nossos instrumentos básicos seriam união, trabalho e dignidade.

Quanto a estrutura do Ensino, sua mudança ficaria a critērio de professores bem experientes na ārea, juntamente com as idéias sugeridas pelos alunos.

Seria fundamental a implantação de uma outra matēria, no caso a sociologia, que se encarregasse da formação do aluno, como um ser social, conscientizā-lo dos seus direitos e deveres, não só como alunos, mas também como homem. Sendo assim, e alunos teria mais motivação quanto ao Ensino e não teria a Escola como simples distribuidora de diplomas. Parte desses problemas pode ser solucionada den tro da prōpria Escola, basta que alunos e professores se proponham a trabalhar num esforço mūtuo.

Temos que deixar bem claro que a Escola somos nōs, alunos-professores e o futuro da mesma depende exclusivamente dos esforços, tanto por parte dos professores como dos alunos.

JOSUEL RIBEIRO SILVA

NO $\quad 21-10 \mathrm{~L}$ 


\section{Anexo X - Textos de Sensibilização - Preparação do I Congresso}

JĀ ESTAMOS MUDANDO A ESCOLA :

1. A questão dos conteúdos:

Nós, professores, pela nossa formação, dificilmente perguntamos se o conteúdo de nosso curso é algo que pode despertar no aluno o interesse pelo aprendizado, se esse conteúdo tem, no mínimo, a possibilidade de despertar no aluno o interesse pela compreensão do mundo que o cerca, se, no convívio diārio com o aluno, que é intermediado pelo conteúdo, estamos possibilitando ao aluno descobrir que é importante a compreensão do mundo para poder mu dā-10.

Os alunos, pela estruturaçāo da escola, por comodismo e/ou por receio do autoritarismo, não questionam o conteúdo de seus cursos, e quando o fazem ē sempre de forma utilitarista, "para que serve essa matēria"?

E preciso que se descubra como fazer para que alunos e professores, atuando conjuntamente, determinem qual o conteúdo de cada uma das disciplinas e a forma (não simplesmente a metodologia) como esses conteúdos devem ser abordados.

Sabemos que os conteúdos e as formas de abordagem, decididas num primeiro momento, sofrerão constantes modificaçōes, mas que não se chegarā a um ideal, pois considero que o ideal é exatamente a mudança constante.

\section{A questão da divisão Humanas/Exatas/Biolōgicas}

Qualquer texto sērio de Educação considera que o aprendizado de todos os ramos do conhecimento humano é fundamental para a boa formação de um indivíduo, isto qualquer professor sabe. 0 que talvez passe despercebido é que os alunos tambëm acham isso, sem terem jamais lido qualquer texto sobre Educaçāo.

Durante a ūitima semana, em conversas com alunos de vārias classes, ficou clara uma proposta geral de uma área única, o retorno ao colegial antigo, com a retirada de algumas disciplinas, consideradas inúteis, e a inclusão de Filosofia e Sociologia. Existe uma lei federal que permite mudanças nos currículos, em especial do 20 grau, no entanto essa lei não foi regulamentada, o que impede a sua aplicaçäo. Existe, porém, uma saĩda: rees truturando-se o curso de Biológicas, dentro da lei antiga, podemos montar um currículo para 1984 que atenda, pelo menos em parte, às necessidades que todos nós, professores e alunos, estamos tendo para começarmos a mudar a es cola.

\section{A questão da Avaliação}

Essa questão está intimamente ligada à questão dos conteūdos. Em essência, não hā porque não avaliarmos se houve ou não aprendizado deste ou daquele conteúdo, o problema maior é determinarmos por que e para que avaliamos, e isto deve ser feito conjuntamente, professores e alunos. 


\section{Anexo X - Textos de Sensibilização - Preparação do I Congresso}

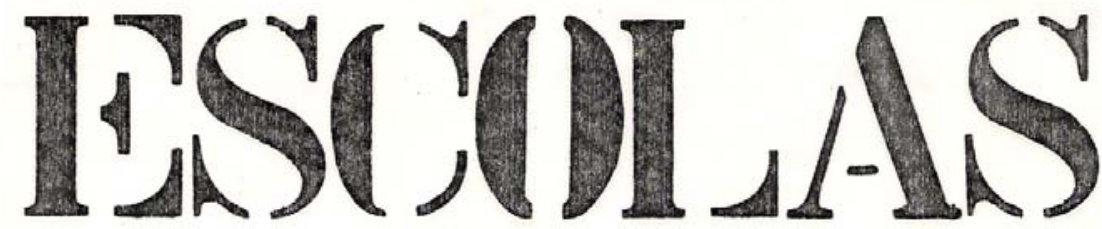

NAS ESCOLAS

ONDE A CULTURA É.INÚTIL

NOS ENSINAM APENAS

A SENTAR E CALAR A BOCA

PARA SERMOS MASSACRADOS

PELL DISCURSO REACIONÁRIO

DE PROFESSORES MARIONETES

CONTROLADOS PELO ESTADO

NAS ESCOLAS

VOCÊ APRENDE

QUE SEU DESTINO JÁ ESTÁ TRAÇADO

POIS QUEREM OS TRANSFORMAR

EM CORDEIRINHOS DOMESTICADOS

PRONTOS PARA SEREM TRANSFORMADOS

EM OPERÁRIOS ESCRAVIZADOS

QUEREM DS TRANSFORMAR

EM MÅQUINAS

PARA SUBMETE-LOS

A CADENCIA DE TRABALHO

E HORÁRIOS EMBRUTECIDOS

PELOS CARRASCOS, PONTEIROS DO RELÓGIO

ME MANDARAM À ESCOLA

PARA ME DOMINAR

ME MANDARAM À ESCOLA

PARA ME MANIPULAR

ME MANDARAM A ESCOLA

PARA ME ESCRAVIZAR

ME MANDARAM À ESCOLA

PARA ME DOMAR

(GAROTOS POORES) 


\section{Anexo X - Textos de Sensibilização - Preparação do I Congresso}

\section{I: CONGRESSO DA EEPAM EESG PROF. AYRES DE MOURA}

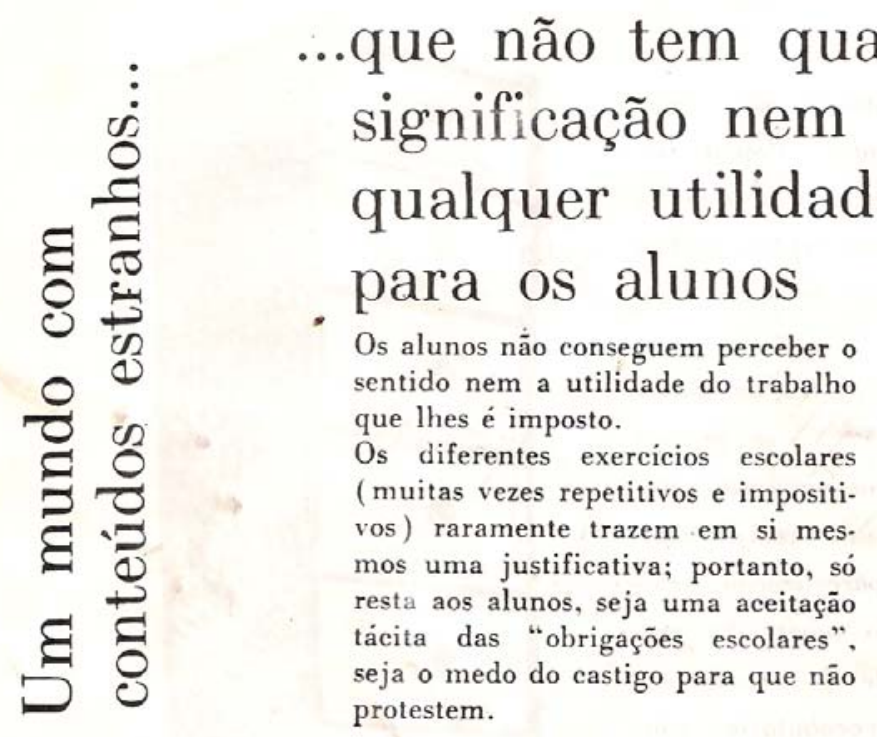

Mas quando chegam a protestar: - Gramática, ai que coisa mais chata!

- Olha, pra que serve a Matemática?

Os adultos, pais ou professores nāo têm então outra coisa a dizer a não ser :

— Essas coisas serão úteis mais tarde!

- Você vai ver quando crescer!
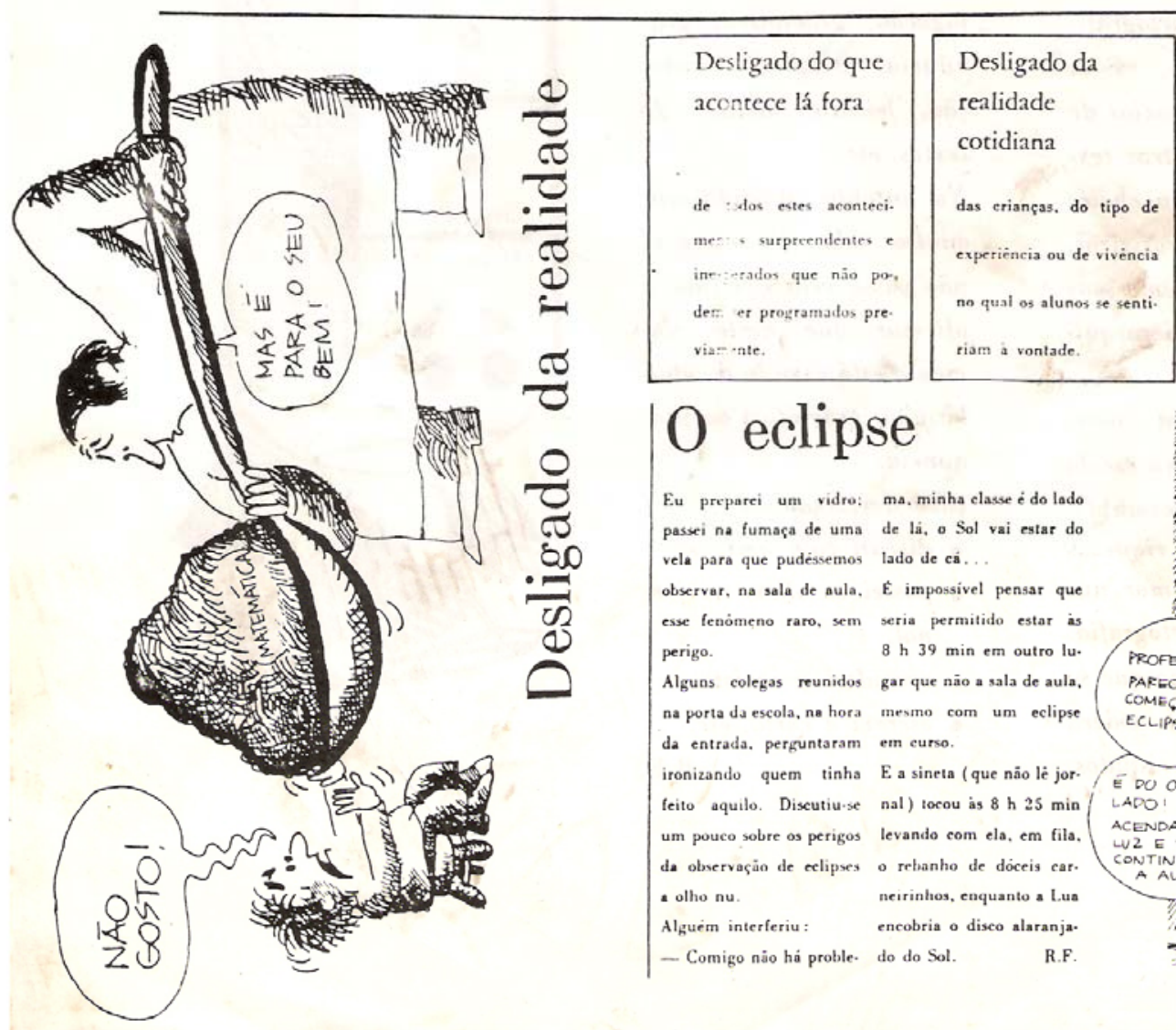

\begin{tabular}{|c|}
\hline $\begin{array}{l}\text { Desligado da } \\
\text { realidade } \\
\text { política }\end{array}$ \\
\hline $\begin{array}{l}\text { que daria sentido ao ensi. } \\
\text { ao. (Saio raras as aulas } \\
\text { onde o que se esereve serve } \\
\text { realmente para uma comu. } \\
\text { nicaça como mundo ex. } \\
\text { terior ou onde a matema. } \\
\text { tica e utilizada para a sa. } \\
\text { luçäo de problemas reais). }\end{array}$ \\
\hline
\end{tabular}

O eclipse

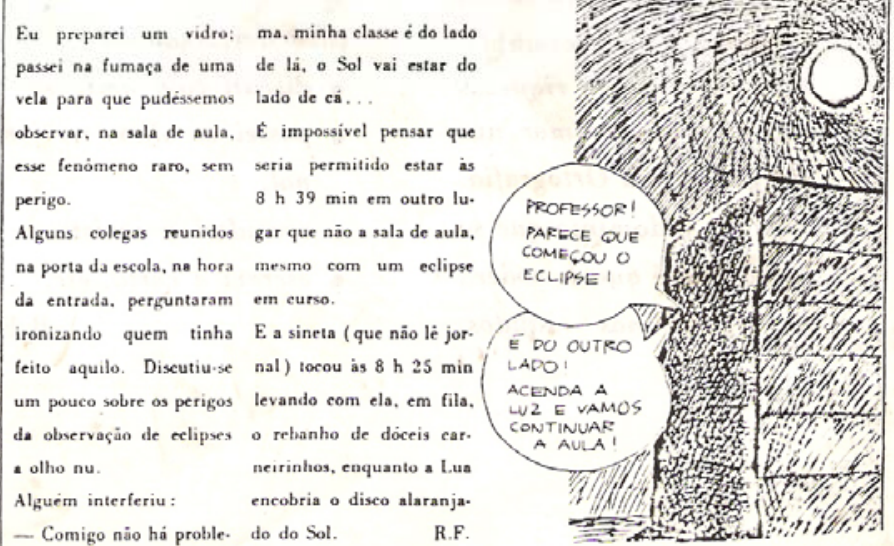




\section{Anexo X - Textos de Sensibilização - Preparação do I Congresso}

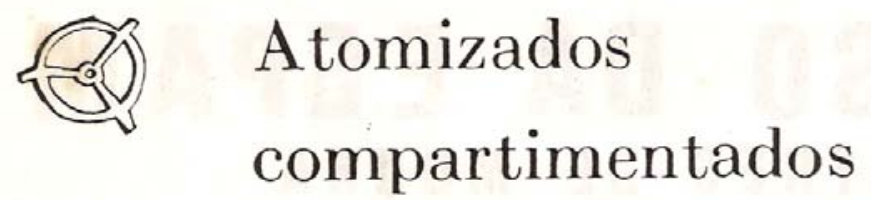

Pela forma com que são ensinadas, cada matéria está destinada a ser cuidadosamente arrumada em sua gavetinha. uma para Gramática, outra para Geografia, uma para Historia, outra para Ortogra. fia. etc., e cada gaveta não se comunica com as outras. Elas se abrem, uma de cada vez. na hora certa. Mas o aluno que dispõe de uma gaveta bem cheia de conhecimentos ortográficos. por exemplo, só os utilizara nos exercicios de ditado, e seus outros textos escritos estarão cheios dos erros mais grosseiros. As gavetinhas têm seus conteudos bem hierarquizados.

Algumas guardam coisas de maior valor. $\mathrm{Na}$ escola primária, por exemplo, uma das maiores riquezas que se pode arrumar numa gaveta $\dot{e}$ a Ortografia. Segundo o dominio que se tenha dela é que se poderá prosseguir nos estudos.
Outras gavetas são menos consideradas. Pouco importa à escola que se tenha uma gaveta repleta de boa muisica ou de belos dese. nhos.

$O$ ensino da lingua materna, tal como se pratica ainda na maioria das aulas. é um exemplo tipico de parcelização arbi. trária do saber. $\mathrm{Na}$ ver. dade, ele $\dot{e}$ cortado em fatias: vocabulário. conjugação. gramática. pronúncia, ortografia, reda. ção. leitura, anailise de textos, etc.

No entanto. quandi) um adulto fala, lê. escreve. não passa pela sua cabeça afirmar que neste momento está usando vocabulário ou gramática ou pronuincia.

Dirá simplesmente:

- discuti com amigos,

- passei os olhos no jornal.

- consultei a revista,

- escrevi a carta, etc.

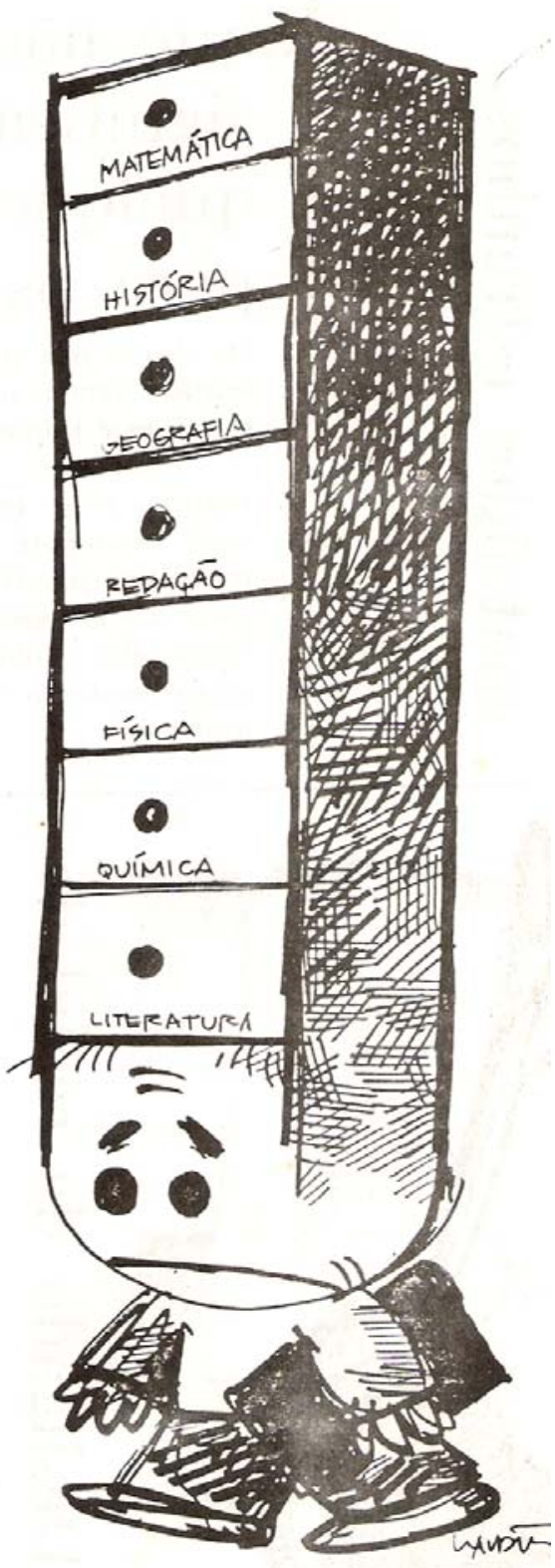

R.F. 